MAURICIO DA SILVA LAGO

\title{
ASPECTOS BIOMECÂNICOS POSTURAIS E ESTRATÉGIAS EM OTIMIZAÇÃO DE PERFORMANCE PARA CONTRABAIXISTAS
}

SÃO PAULO

2010 


\section{ASPECTOS BIOMECÂNICOS POSTURAIS E ESTRATÉGIAS EM OTIMIZAÇÃO DE PERFORMANCE PARA CONTRABAIXISTAS}

Dissertação de Mestrado apresentada ao Departamento de Música da Escola de Comunicações e Artes da Universidade de São Paulo.

Área de Concentração: Processos de Criação Musical

Linha de Pesquisa: história, teoria, análise e aspectos técnicos envolvidos na prática interpretativa

Orientador: Prof. Dr. Sérgio Cascapera

\section{SÃO PAULO}


BANCA EXAMINADORA 


\section{DEDICATÓRIA}

Ao meu amado pai Carlos Alberto da Silva que infelizmente nos deixou ao longo deste trabalho, dedico a ele essa conquista como gratidão, pelo amor, carinho e estímulo que sempre me ofereceu. 


\section{AGRADECIMENTOS}

Agradeço a minha Mônica por estar presente em todos os momentos importantes de minha vida, pelo suporte, amor e afeição.

Agradeço a grande ajuda de meu orientador, Dr. Sérgio Cascapera, pela paciência e carinho com que sempre me acolheu.

Agradeço a meus colegas contrabaixistas pela contribuição de forma direta ou indireta no presente trabalho. 
"Aprenda as regras, assim você saberá quebrá-las corretamente."

\section{Dalai Lama}




\title{
ASPECTOS BIOMECÂNICOS POSTURAIS E ESTRATÉGIAS EM OTIMIZAÇÃO DE PERFORMANCE PARA CONTRABAIXISTAS
}

\begin{abstract}
RESUMO
O presente projeto pretende analisar os fundamentos mecânicos das atividades musculares, com estudos detalhados e relacionados que trarão à baila aspectos práticos, biomecânicos, fisiológicos e teóricos, como também distinções técnicas, vantagens e desvantagens em certos métodos adotados no passado, na atualidade e perspectivas do Contrabaixo Acústico, no século XXI.
\end{abstract}

PALAVRAS-CHAVE: contrabaixo acústico, ergonomia, movimentos, metodologia, arcos alemão e francês. 


\title{
ASPECTOS BIOMECÂNICOS POSTURAIS E ESTRATÉGIAS EM OTIMIZAÇÃO DE PERFORMANCE PARA CONTRABAIXISTAS
}

\begin{abstract}
This project aims to examine the fundamentals of mechanical muscle activity, with detailed and related studies. It will bring to the fore the practical aspects, biomechanical, physiological and theoretical distinctions as well as technical advantages and disadvantages of certain methods adopted in the past, present and prospects Acoustic Bass, in the twenty-first century.

KEYWORDS: double bass, ergonomics, motion, methodology, German and French bows.
\end{abstract}




\section{SUMÁRIO}

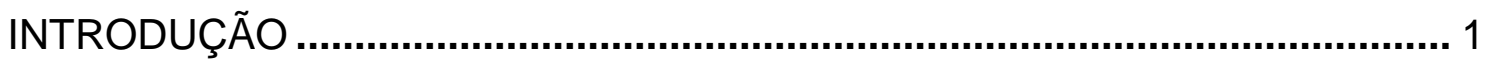

O CONTRABAIXO E SUA FUNÇÃO ATRAVÉS DA HISTÓRIA ...................... 2

Dados históricos do instrumento ............................................................ 5

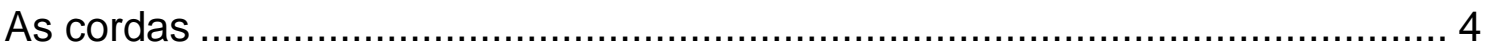

O INSTRUMENTO E A ANÁLISE BIOMECÂNICA POSTURAL ....................... 8

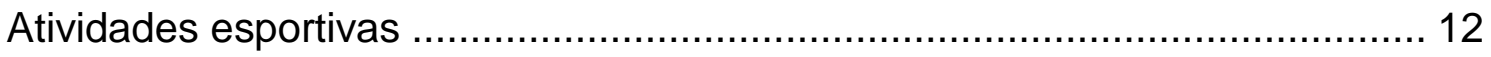

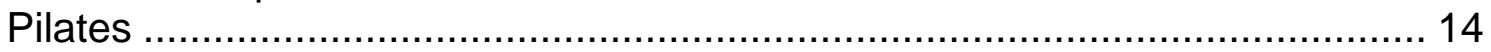

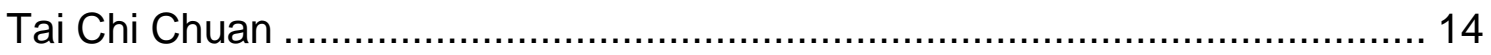

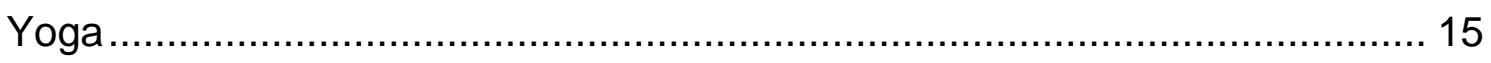

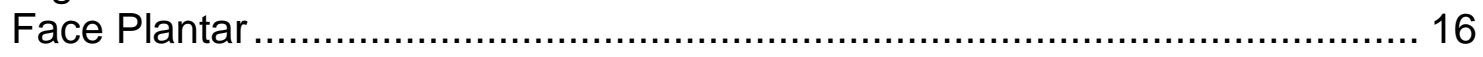

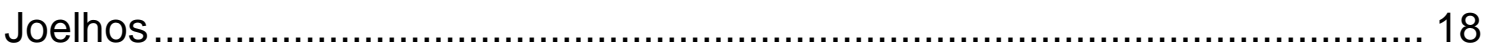

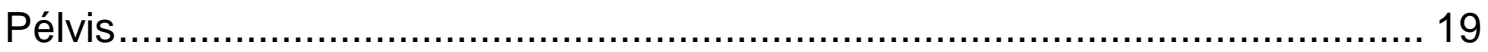

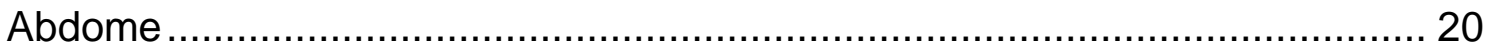

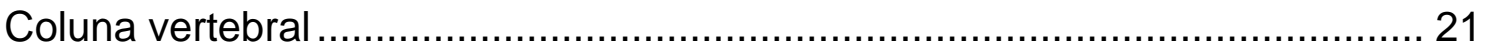

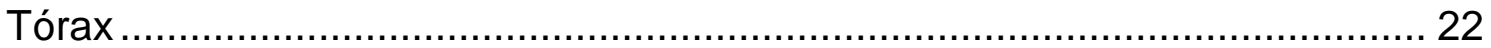

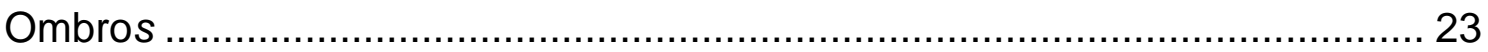

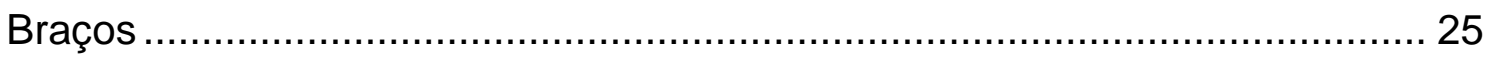

Cervical, pescoço e maxilar................................................................. 26

Posição postural - (maneira como se segura o instrumento) em pé............... 27

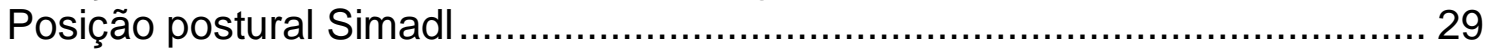

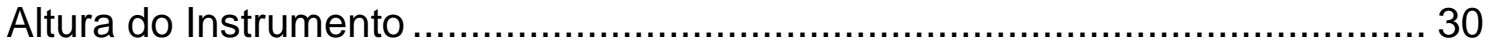

Posição postural Billè ........................................................................ 31

Posição postural Ludwig Streicher .................................................... 32

Posição Postural - (segurando o instrumento na posição sentada)................. 36

Posição postural sentada ângulo do instrumento semelhante à postura em pé38

Tipos de cadeiras e assentos ...................................................................... 39

Posição postural Miroslav Gadjos ........................................................... 41

Posição postural Wolfgang Gütler ...................................................... 43

Posições Comparadas .................................................................. 44

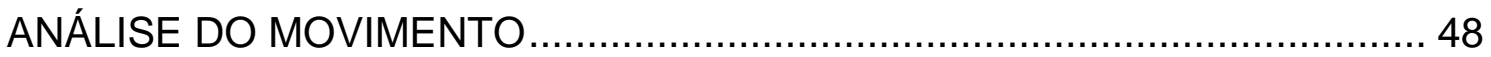

As três fases do movimento; preparação, movimento e restabelecimento ...... 50

Movimentos ativos e passivos ............................................................. 52

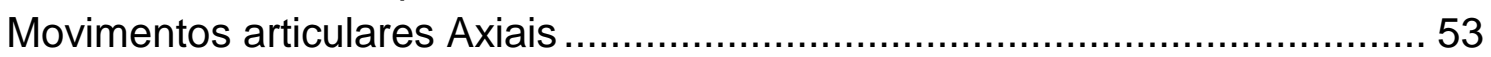

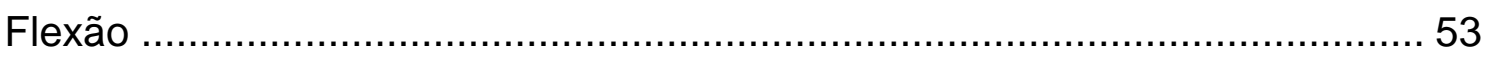

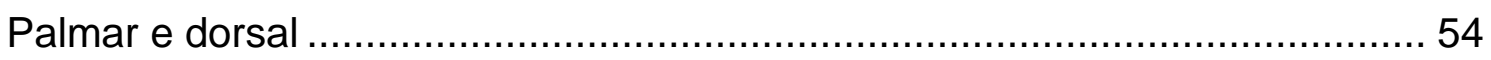

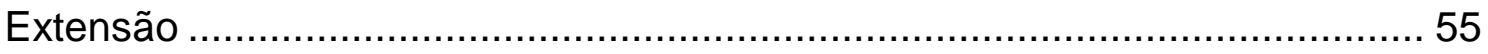

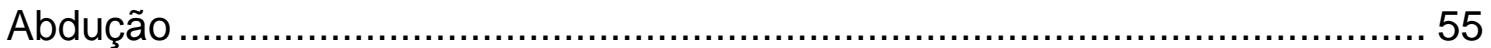

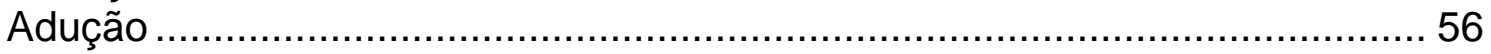

Rotação Interna ou Externa.................................................................. 57 
Pronação

DORES RELACIONADAS À PRÁTICA DO INSTRUMENTO .......................... 59

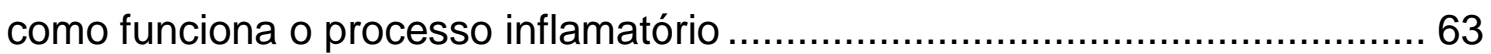

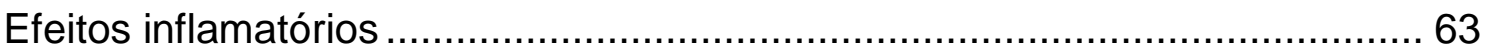

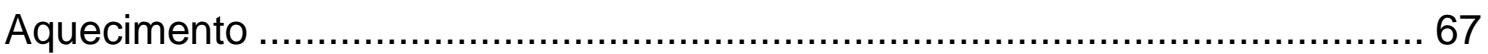

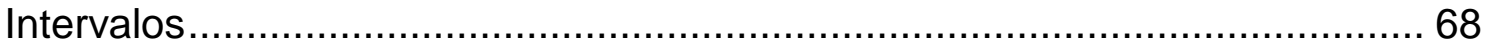

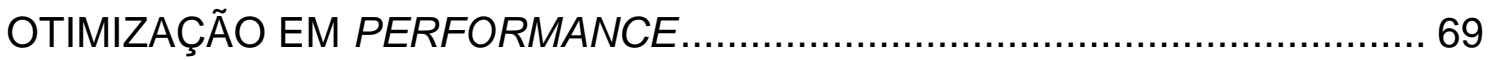

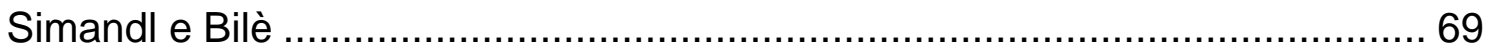

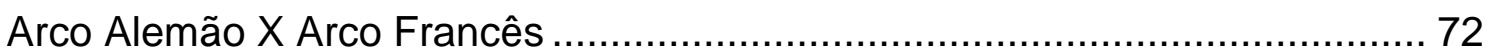

Aspectos físicos do arco em relação às cordas …………........................... 74

Posição postural arco alemão ................................................................... 77

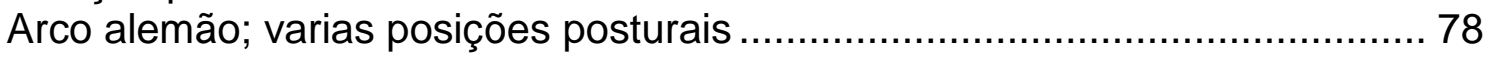

Posição postural arco francês ................................................................. 79

Arco francês; varias posições posturais ..................................................... 79

Considerações sobre arcos francês e alemão …………............................. 80

Técnica de mão direita; grupos básicos de golpes de arco ............................ 86

Considerações sobre pressão e ponto de contato do arco em contato com a

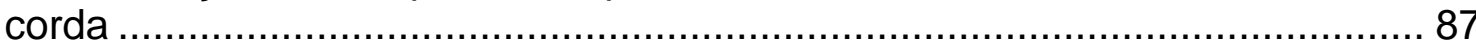

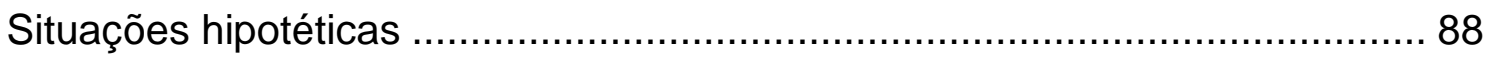

Considerações sobre dedilhado e posição braço ............................................. 88

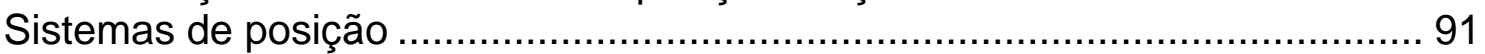

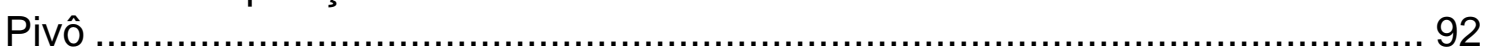

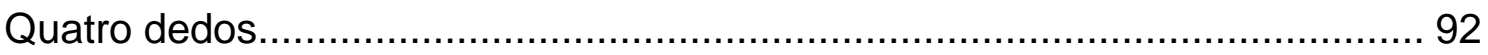

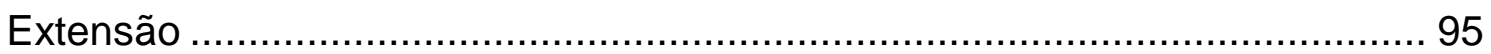

Outros sistemas de digitação de mão esquerda ………………………....... 96

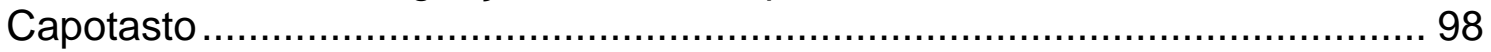

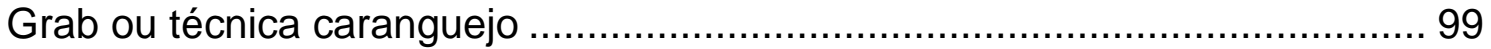

Estudo comparativo sobre mudança de posições ......................................... 99

Ludwig Streicher - escola austríaca......................................................... 100

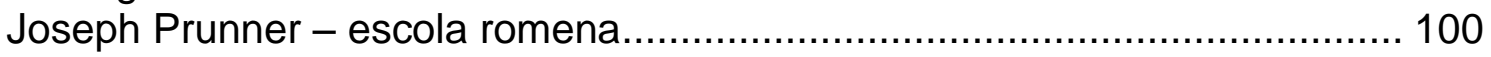

Jean-Marc Rollez - escola francesa ....................................................... 101

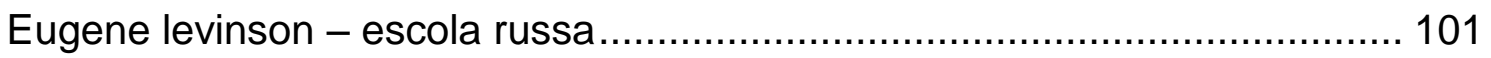

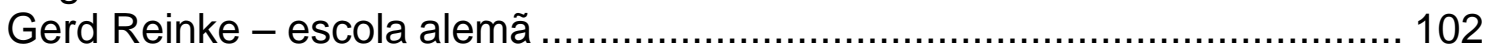

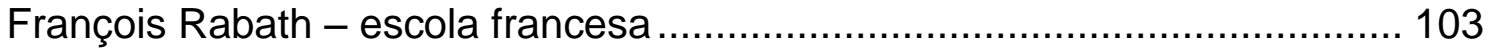

Mark Morton - escola americana ......................................................... 103

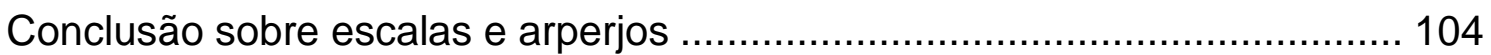

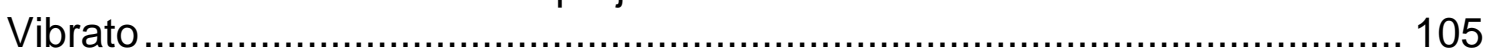

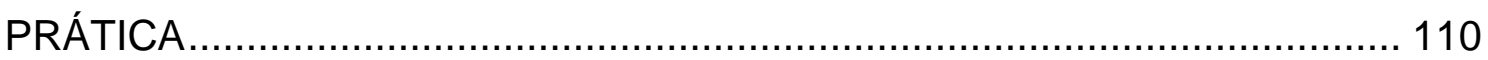

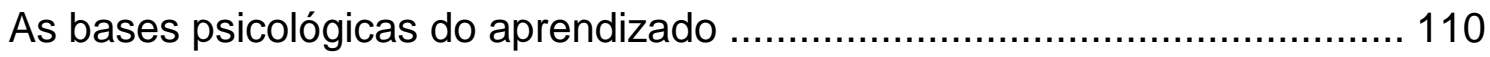

Ambiente para a prática ...................................................................... 111

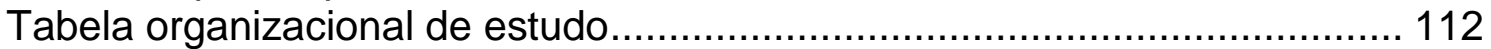

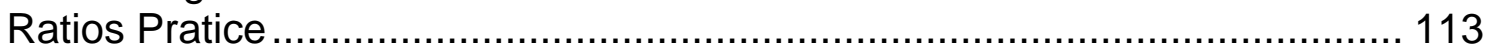

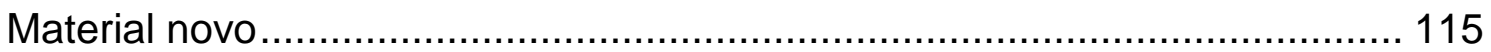

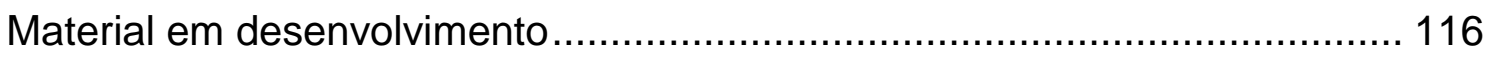

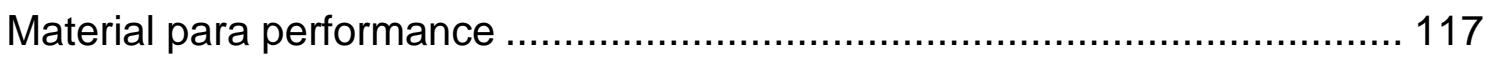

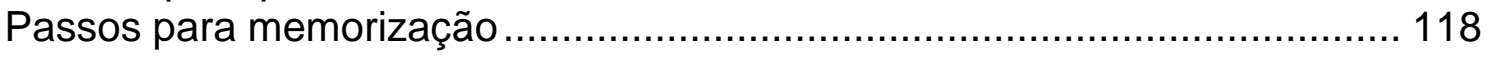


Técnica.

Musicalidade, leitura a primeira vista, percepção, composição e improvisação, apreciação musical

Plano de prática 120

Gary karr - considerações sobre prática............................................... 121

Jeff Bradetich - considerações sobre prática ............................................. 122

PREPARANDO-SE PARA A PERFORMANCE ........................................... 123

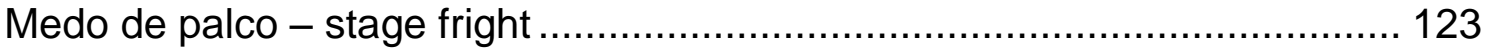

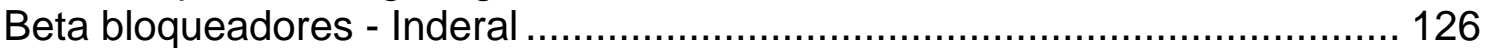

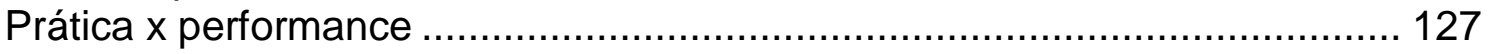

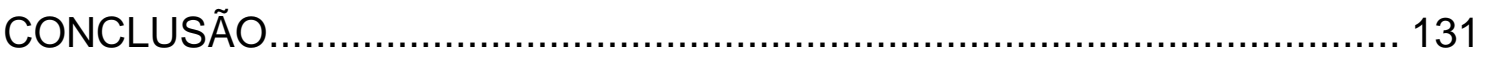

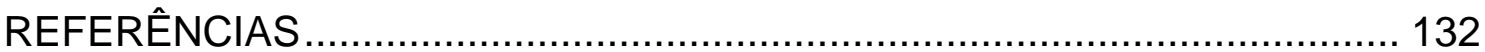




\section{INTRODUÇÃO}

O presente estudo é resultado de pesquisas e práticas acerca do Contrabaixo. As teorias não são apenas pelo viés da musicalidade, envereda-se também pela anatomia e as consequências que o corpo sofre com a constância de estudos, ensaios e performances.

Pretende-se trazer à baila tanto aspectos práticos, biomecânicos, fisiológicos e teóricos, bem como as distinções técnicas de vantagens e desvantagens nos métodos adotados para a execução desse instrumento.

A partir da contextualização histórica, unida a pensamentos modernos na metodologia do estudo do instrumento, traçam-se paralelos nas mais diversas formas de tocar o Contrabaixo Acústico.

A busca, enfim, desta pesquisa enfatiza a otimização da performance. Do mesmo modo, a partir do conhecimento histórico, de cada uma das principais técnicas e práticas, além de trazer exemplos práticos musicais de temas específicos. 


\section{O CONTRABAIXO E SUA FUNÇÃO ATRAVÉS DA HISTÓRIA}

É fonte desconhecida sobre a quem se atribui verdadeiramente o mérito pela invenção do primeiro instrumento de cordas, pois não há elementos históricos suficientes para atribuir seu real inventor, ou melhor, sua história é perdida e dificilmente sairá da escuridão, foi perdida através dos séculos.

A lenda atribui a invenção ao deus romano Mercúrio; por outro lado, a história mostra que os instrumentos de cordas, tocados por arco, são provenientes da civilização da Índia, enquanto os instrumentos dedilhados são atribuídos ao Egito e à Grécia. $^{1}$

O estudo da origem do Contrabaixo Acústico torna-se peculiar, talvez pelo fato de sua evolução revelar-se não uniforme. É fato que as afirmações, em sua maioria; são controversos no que tange sua construção e origem.

De forma geral, a evolução Contrabaixo Acústico inicia-se com os liutaios ${ }^{2}$ (luthiers) construtores; Gasparo da Salò e a famosa família Amati, na Itália por volta de 1560 . $^{3}$ A escola italiana, "leia-se", o método tecnológico de construção do instrumento, tem seu início por volta de 1580, em Cremona com esses principais construtores e Paolo Maggini.

Esses importantes pioneiros foram seguidos por ninguém menos que Stradivarius, um gênio na Arte de construir violinos, embora infelizmente não se tenha notícia de nenhum contrabaixo construído por ele.

"A orquestra deve muito ao Contrabaixo. O Contrabaixo por sua vez não deve absolutamente nada a orquestra". ${ }^{4}$ Com essa afirmação iniciamos a pesquisa sobre aspectos históricos e evolucionários do instrumento, usado para a execução de música religiosa, nos séculos XV e XVI, ou seja, duzentos e cinquenta anos antes do aparecimento de qualquer grupo orquestral que, na atualidade, chamamos de orquestra; onde o uso e a aplicabilidade são mais notórios.

\footnotetext{
${ }^{1}$ BILLÈ, Isaia. Nuevo Metodo per contrabasso, pag. III

${ }^{2}$ Luthier (Fr.; it. Liutaio) Significando literalmente "fabricante de alaúdes", genericamente passou a designar fabricante de violinos, ou outros instrumentos de cordas. Da mesma forma, a derivação "lutheirie" (fabricação de alaúdes; encontram-se em português luteria e luteraria) aqdquiriu o significado de fabricação de instrumentos em geral, particularmente os de cordas. GROOVE, Dicionário de Música Edição Concisa. p. 555.

${ }^{3}$ GREEN, Barry. Advanced Techniques of Double Bass Playing, p. 209.

${ }^{4}$ GOÏLAV, Yoan. The Double Bass - A PHILOSOPHY OF PLAYING, p. 12.
} 
Era utilizado ao lado do órgão que, naquela época, predominava nas igrejas e tinha o contrabaixo a seu serviço, para acompanhamento. O órgão, por sua vez, composto por chaves que habilitam ou desabilitam a passagem do ar para determinado conjunto de tubos, possuía tamanho desproporcional e era operado manualmente. Disso decorriam deficiências mecânicas, visto que os tubos tinham diversos tamanhos e larguras o que prejudicava a vibração e a produção do som, especialmente em dinâmicas fortes.

Para reduzir as deficiências, nasceu a ideia de "dobrar" os sons graves produzidos por esse grande e poderoso instrumento, cuja sustentação era propiciada pelo contrabaixo, nas notas graves.

O contrabaixo assumiu muitos nomes e formatos diferentes, como aconteceu em escala evolucionária com diversos instrumentos musicais, tal qual o trompete que já era usado na Antiguidade, inclusive na era de Tutankamon - e, sem dúvida alguma, se tratava do instrumento de sopro muito próximo do que conhecemos hoje.

A criação do Contrabaixo Acústico, utilizado na atualidade ou da maneira mais comum que conhecemos, atribui-se a Todini Michele (Saluzzo, 1625-1689), criador de um tipo de Arciviola muito análogo ao instrumento de nossos dias. Outras fontes reputam o invento ao liutaio tirolês Gaspard Duffoproucaut (1514-1562), nascido em Freising, Alemanha. Por fim atribuiu-se mesmo a Gasparo da Saló.

Vários foram os formatos. Da Viola da Braccio, por diminutivo, derivou o Violino, por volta de 1550. Do registro Alto surgiu a atual Viola; da Viola da Gamba Tenor surgiu o Violoncelo; e, por fim, da Arciviola ou Violone ${ }^{5}$ nasceu o Contrabaixo. $\mathrm{Na}$ partitura de Orfeu, apresentado pela primeira vez em 1607, em Mântua, Monteverdi (1567-1643) solicitava Duoi Contrabassi di Viola, também chamados de Violini Ganassi - instrumentos de seis cordas, afinadas em quartas, com uma terça entre a segunda e terceira delas, assim como o Alaúde ou o moderno Violão. ${ }^{6}$

E, ainda, de forma simples o Violone que, em Italiano, é o superlativo de viola e tornou-se depois o instrumento muito semelhante ao que hoje conhecemos CONTRABASSO.

\footnotetext{
${ }^{5} \mathrm{Na}$ terminologia moderna, a viola contrabaixo, ancestral direta do contrabaixo. Historicamente, no entanto, a designação é bem imprecisa, abrangendo toda uma variedade de significados; qualquer viola, uma viola grande (particularmente uma viola da gamba de afinação grave) e mesmo (em algumas fontes italianas) um violino baixo ou violoncelo. GROOVE, Dicionário de Música, Edição Concisa. p. 1001.

${ }^{6}$ DOURADO, Henrique Autran, tese de doutorado, São Paulo: USP, 1998, p.41.
} 
Em capítulo específico, será tratada a produção de som desse instrumento, além de citar escolas, tipos de arco e especificidades. Outro aspecto igualmente importante é a construção do instrumento, a partir do conhecimento sobre as cordas.

\section{As Cordas}

A priori, há centenas de anos, as escolhas de cordas para instrumentos musicais são diversas, como relata Daniel Larson ${ }^{7}$ :

Em milhares de anos as escolhas envoltas aos materiais utilizados nos instrumentos musicais, conseqüentemente pela evolução técnica da humanidade tiveram algumas mudanças. Usualmente era limitada ao uso de materiais indígenas e funcionava satisfatoriamente bem para esta tarefa. $\dot{E}$ claro se o músico vive no oriente ou em algum país asiático onde a seda e as fibras eram processadas em tecidos, de certa forma foi usado para fins "musicais". De outro lado a crina animal (retirada do rabo do cavalo ${ }^{8}$ se nativo da Escandinávia, já seria de fato o precursor do material usado nos dias de hoje. Em um clima tropical de forma lógica o material a ser usada certamente serão fibras de plantas processados de certa forma a atenderem a função de corda para um instrumento musical adequado a sua cultura. No oeste da europa foi escolhido um material muito improvável para ser usado como cordas musicais: INTESTINOS DE ANIMAIS.

No atual instrumento, bem como nos da família: violino, violoncelo e viola e demais instrumentos de cordas dedilhadas ou friccionadas, eram utilizadas cordas de origem animal para a produção de som. Estas, grosso modo, eram manufaturadas por um especial processo, pelo qual se retirava o intestino animal (preferencialmente de ovelhas).

Apesar de as cordas de tripas já estarem em desuso, em meados do século $X X$, sua utilização não foi totalmente extinta, pois ainda é empregada por grupos que se denominam produtores de música antiga de forma purista e tentam reproduzir de modo fidedigno o que era executado à época.

Sem prejuízo à música antiga, alguns contrabaixistas na atualidade adotam o uso dessas cordas para a execução de músicas dos mais variados estilos como

\footnotetext{
${ }^{7}$ LARSON, Daniel. Liutaio construtor e especialista em instrumentos antigos.

8 Liutaios: responsáveis pela instalação de crinas nos arcos dos instrumentos da família das cordas, (ex.: violino, viola, cello e contrabaixo-acústico), preferem as crinas animais retiradas de cavalo. Isso ocorre porque a égua costuma urinar no rabo, o que prejudica a boa qualidade da crina, para o uso já explicado.
} 
Rockabilly - um dos inúmeros subgêneros do Rock and Roll, conhecido nos anos 1950 - e o Bluegrass, forma de música popular e tradicional americana, com raízes nas ilhas britânicas, na música rural dos negros, e mesmo no Jazz e no Blues, em que muitos contrabaixistas preferem sua utilização, pois facilita a execução do slap (técnica pela qual o músico extrai som percussivo - semelhante ao pizzicato Bartok, usado em peças orquestrais). Como relata Mingus ${ }^{9}$, quando menciona sua predileção pelas cordas de tripa animal.

A mudança de cordas de tripa animal para as conhecidas hoje, como as de metal, trouxeram avanço técnico para o instrumento, isto é, foram eliminadas muitas deficiências inerentes às cordas de tripa, tais como: impossibilidade de regular 0 instrumento com cordas baixas (próximas ao espelho; o que facilita comprimi-las). Esse avanço se dá graças a metais como tungstênio, aço e níquel e a variedade de marcas, tensões e maneiras de construção.

Franz Simandl, em sua obra do século XIX: New Method for the Double Bass, desenvolve método, um dos mais famosos do mundo para o contrabaixo, sem contemplar exercícios na corda $\mathrm{E}$ (mi), corda IV em afinação de orquestra por conta da impossibilidade de ser comprimida pela mão esquerda na região média para aguda do instrumento por conta das "antigas cordas de tripa animal".

Todavia, com as novas cordas de metal, tornou-se possível tocar em todas as cordas, de forma muito clara e maximizada. Nesse mesmo sentindo, e de acordo com aquilo em que acreditamos, ninguém menos que Eugene Levinson, russo naturalizado americano, $1^{\circ}$ Contrabaixista da Filarmônica de Nova York, ensina:

Controle do arco e seus golpes adequados com o braço são absolutamente vitais. Em meu estilo próprio de tocar é uma adaptação dos princípios enunciados pelo grande pedagogo do violino, Carl Flesch, de quem as escalas e arpejos exploram todo espelho do instrumento. Antigamente esta adaptação era muito difícil e tortuosa no contrabaixo, felizmente nos dias atuais se torna possível pelo surgimento das cordas de metal. Além disso, os estudantes de agora são muito mais ágeis do que os contrabaixistas de uma ou duas gerações passadas; eles podem achar as notas não apenas olhando, mas de forma sinestésica, igualmente como ocorre com outros instrumentistas de cordas.

\footnotetext{
${ }^{9}$ MINGUS, Charles (1922-1979) contrabaixista, compositor e ocasionalmente pianista de jazz.
} 
Com o propósito de visitar o panorama geral sobre o contrabaixo, devemos mencionar também a polêmica mitigada pelo tempo, em relação à quantidade de cordas do contrabaixo.

De fato, um dos instrumentos originários, que mais tarde daria lugar ao contrabaixo, foi a Viola, de acordo com forma, dimensão e número de cordas - de três a doze, total impraticável pelo contrabaixo, responsável pelas frequências graves.

Dessa forma, por questões de ordem prática e física, o contrabaixo acústico foi limitado a quatro ou cinco cordas, hoje. Apesar disso, o grande compositor e solista Giovanni Bottesini ${ }^{10}$, (1821-1889), que tocava contrabaixo Testore, [Testore it.] de três cordas de tripas, responsável pela ascensão do contrabaixo como instrumento solista; e Domênico Dragonetti ${ }^{11}$, (1763-1846) não precisavam de uma quarta ou quinta corda para produzir essa Arte.

Portanto, superada a adição da quarta corda no Contrabaixo Acústico, hoje é muito comum os de cinco cordas em orquestras sinfônicas, além da usual afinação F\#, B, E, A, usada em especial quando se modifica a função original de instrumento acompanhador para solista.

Há outras afinações, porém não são habitualmente utilizadas por todos os contrabaixistas, por exemplo, Joel Quarrington ${ }^{12}$ era adepto a afinar o contrabaixo em quintas: $G, C, D, A$.

Este capítulo teve como escopo principal, ainda que de forma básica, situar o leitor na historicidade do Contrabaixo Acústico. Noutro passo, não é nosso interesse

\footnotetext{
${ }^{10}$ Giovanni Bottesini (Crema, 22 de dez 1821; Parma, 7 jul 1889) Contrabaixista, regente e compositor italiano. Estudou no conservatório de Milão, tornou-se o principal baixista principal do Teatro de São Benedetto, Veneza, fazendo turnês pela Europa e América do Norte. Tocando um instrumento de três cordas, afinado uma tonalidade mais alta do que era comum, foi apelidado de "Paganini do contrabaixo", por apresentar agilidade, pureza sonora e entonação. Foi amigo de Verdi durante toda a vida e cumpriu compromissos de regência nos teatros de Paris, Palermo, Espanha, Portugal e Londres. Entre as obras cênicas, Vinciguerra il bandito (1870) e Erro e Leandro (1879, libreto de Boito) foram bem recebidas. É mais lembrado por suas composições numerosas e tecnicamente exigentes para o contrabaixo, expandindo o âmbito do instrumento. GROOVE, Dicionário de Música, Edição Concisa. p. 125.

${ }^{11}$ Domenico Dragonetti (Carlo Maria) (Veneza, 10 de abr 1763; Londres, 16 de abr 1846) Contrabaixista e compositor italiano. Tocou em orquestras e teatros venezianos, antes de estabelecer-se em Londres, 1794, apresentando-se regularmente em concerto e festivais de província durante o meio século que se seguiu; ganhou fama por suas interpretações expressivas e virtuosísticas num instrumento grande, de três cordas, com o violoncelista Robert Lindley. Suas obras numerosas, a maioria para contrabaixo, incluem oito concertos e mais de 30 quintetos de cordas. Seu contrabaixo gigantesco encontra-se hoje no Victoria na Albert Museum, Londres. GROOVE, Dicionário de Música, Edição Concisa.p. 278.

${ }^{12}$ Principal Bassist of the National Arts Centre Orchestra in Ottawa.
} 
esgotar todos os assuntos especificamente ligados a ele, posto que serão abordados de forma específica em capítulos posteriores. 


\section{O INSTRUMENTO E A ANÁLISE BIOMECÂNICA POSTURAL}

Uma das qualidades essenciais para ser músico e tocar um instrumento, ou seja, "fazer música", é meramente a forma intuitiva. ${ }^{13} \mathrm{O}$ que não impede que o processo seja aperfeiçoado também de forma intelectual, levando em conta que o ser humano evolui, interage com o meio e, em seu campo de concentração, tenta a plenitude, ou seja, o sucesso artístico que muitas das vezes toma a vida inteira.

O sucesso, aliás, é a parte material ou o conjunto de processos da $\operatorname{Arte}^{14}$, a qual será denominada técnica, utilizada para sua execução.

O presente trabalho relata também a Biomecânica ${ }^{15}$, como estudo do movimento humano ${ }^{16}$. Desse conceito serão feitas algumas considerações, inerentes e de forma comparada, a fim de comprová-la como método para melhorar o desempenho em executar o Contrabaixo Acústico. Por sua vez, a Biomecânica está em diversas áreas de atuação: Educação Física, Fisiologia ${ }^{17}$, Ergonomia $^{18} \mathrm{e}$ demais ramificações atreladas ao tema. Em virtude disso, neste estudo será utilizado o benefício que essa área oferece para a melhora na prevenção de lesões e na reabilitação. ${ }^{19}$ Essa ciência é ainda utilizada em vários outros segmentos ${ }^{20}$ :

- rendimento no Esporte

- reabilitação

- instrumentação e métodos

- ocupacional e ergonomia

\footnotetext{
${ }^{13}$ WOLF Michael, Principles of Double Bass Technique, p 13.

${ }^{14}$ AURÉLIO, Dicionário da Língua Portuguesa.

${ }^{15}$ BIOMECÂNICA é o estudo dos fundamentos mecânicos das atividades biológicas em especial as musculares. (Aurélio, obra cit.)

${ }^{16}$ WINTER, 1979.

${ }^{17}$ FISIOLOGIA é a parte da biologia que investiga as funções orgânicas processos ou atividades vitais como o crescimento, a nutrição, a respiração e etc. (AURÉLIO, obra cit.)

${ }^{18}$ GRANDJEAN, E. A Ergonomia é uma ciência interdisciplinar. O objetivo prático da Ergonomia é a adaptação do posto de trabalho, dos instrumentos, das máquinas, dos horários, do meio ambiente às exigências do homem. A realização de tais objetivos, ao nível industrial, propicia facilidade do trabalho e rendimento do esforço humano. (1968)

${ }^{19}$ Marchetti, Paulo; CALHEIROS, Ruy e CHARRO, Mario. Biomecânica Aplicada. Uma abordagem para o treinamento de força. (2007)

${ }_{20} \mathrm{http} / / /$ www.fm.usp.br/fofito/fisio/pessoal/isabel/biomecanicaonline/elementar/historia.php acesso em junho de 2008.
} 
Para o tema proposto, e com o objetivo primário de aperfeiçoar a performance, pretende-se também situar o leitor nas peculiaridades do desempenho.

De meados dos anos 1580, data de que se tem notícia do primeiro contrabaixo construído, a forma do instrumento não evoluiu de forma expressivamente ergonômica até o momento, apesar de os relatos ainda que remotos sobre os estudos pregressos sobre a ergonomia ${ }^{21}$ : onde há relato de seu surgimento logo após a Segunda Guerra Mundial, como consequência do trabalho interdisciplinar de diversos profissionais como engenheiros, fisiologistas e psicólogos, que foram mobilizados durante aquela guerra. De maneira inicial, essa aplicação ocorria quase que exclusivamente na indústria e concentrava-se no binômio homem-máquina. Hoje essa expansão se processa principalmente no setor de serviços (saúde, educação, transportes, lazer, outros) e até no estudo de trabalhos domésticos.

O trabalho abrange não apenas máquinas e equipamentos utilizados para transformar os materiais, mas também toda a situação em que ocorre o relacionamento entre o homem e seu trabalho. Isso envolve, além do ambiente físico, os aspectos organizacionais sobre como esse trabalho é programado e controlado, para produzir os resultados desejados.

Todavia essa visão ergonômica, já difundida em vários segmentos da sociedade, é ainda inexpressiva na atualidade no cenário musical; assim, não é dado o devido valor a esse campo, tendo em vista a ausência em grande parte na literatura do Contrabaixo Acústico, para não dizer quase inexistente.

Com propósito baseado na ergonomia, os músculos do corpo podem ser treinados para os objetivos pretendidos, quando se trata de tocar um instrumento, e deverão ser treinados, antes mesmo que o músico se concentre especificamente na prática do instrumento.

Com isso se pode afirmar que o instrumentista deve aprender, desde o início de seus estudos musicais, os movimentos necessários de forma correta, com a

\footnotetext{
${ }^{21}$ SELF (Sociedade Ergonômica de Língua Francesa)- A Ergonomia reúne conhecimentos da fisiologia e da psicologia, e das ciências vizinhas aplicadas ao trabalho humano, na perspectiva de uma melhor adaptação ao homem dos métodos e meio ambiente de trabalho.
} 
consciência exata da funcionalidade do corpo. Se esses movimentos forem usados nos estágios iniciais do aprendizado musical e mantidos em estágio avançado quando o instrumentista já é músico profissional, ele adquirirá prática/postura relaxada sem tensões, ou seja, o sonho de grande parte dos músicos: a execução de seu instrumento com ausência de tensões ou, como diz a professora Susan Kempter; stress-free. ${ }^{22}$

Essa sugestão de consciência com foco na execução do instrumento com atitude relaxada (stress-free), apenas faz parte da otimização de performance, ou seja, a ausência de tensões não provocará dores musculares tampouco desconforto. Desse modo, o instrumentista estará com o raciocínio focado tão somente nos objetivos inerentes a própria execução musical.

Tome-se, como exemplo, um instrumentista totalmente tenso e com fortes dores musculares. Como obter bons resultados na execução do instrumento?

A resposta para essa pergunta pode ser um sonoro: depende. Ainda que ele consiga executar de forma satisfatória seu instrumento, basta imaginar a seguinte proporção matemática estando ausentes os princípios ergonômicos. O músico perde $30 \%$ do aproveitamento, devido à má postura, ou seja, uma postura para a qual o corpo humano não foi projetado e, consequentemente, a longo prazo desenvolverá alguma patologia. Por exemplo, o uso de uma cadeira ruim causa tensão corpórea, ausência de centro de gravidade e má postura, o que sobrecarregará alguns músculos e detrimento de outros.

Some-se a isso mais $30 \%$, por não ter um plano de estudo satisfatório, que alcance as especificidades do instrumento. Por exemplo, conhecer bem escalas, arpejos, excertos orquestrais, no caso de músicos de orquestra e repertório. Sem olvidar outro aspecto também fisiológico que, sem dúvida, também pode ser atrelado ao ramo da ergonomia, o tão comum "medo de palco" que reduz mais $30 \%$.

Confirmados esses cálculos restariam "meros" $10 \%$ para a realização musical. Por isso, deve-se sempre, ao menos, tentar eliminar fatores exteriores limitadores à realização profissional para obter a otimização em performance - tema principal deste estudo.

\footnotetext{
${ }^{22}$ KEMPTER, SUsan. How Muscles Learn.
} 
A análise postural, ou seja, a utilização do corpo de forma correta, ainda não integra a grade curricular das instituições de ensino musical. Atrevemo-nos, entretanto, a dizer que - num futuro não muito distante - será fato a sua inclusão nas matérias acadêmicas.

O resultado dessa futura inclusão, como já ressaltamos em várias oportunidades, será prever, resguardar e preservar a integridade física proporcionada pela jornada árdua que tem o músico instrumentista nos dias de hoje.

No presente capítulo iremos nos ater somente a alguns ramos de atuação dessa ciência tais como: noções básicas e comparadas da funcionalidade músculoesquelética para tocar contrabaixo.

Nosso objetivo é adentrar em duas subdivisões do campo científico: a mecânica (que estuda o movimento) e a cinemática (que estuda a descrição do movimento).

Parece-nos mais adequado, e fará sentido no campo performático, dar ênfase à cinemática, pois a consciência e a análise do movimento trarão benefícios de ordem prática para o músico instrumentista.

O leitor deve estar pensando o que levaria alguém a escrever sobre esse tema. Músicos de forma geral, ainda que minimamente, tiveram alguma experiência com a dor. Seja lá por qual motivo: má posição postural ou devido ao alto número de repetições que poderá desencadear processos inflamatórios, a partir dos quais o músico poderá desenvolver LER ou DORT provocados por overuse (gerado por estudo, prática ou performance de forma exacerbada, além dos limites do corpo) ou até mesmo de maneira mais corriqueira, como o uso indevido ou não ergonômico de esqueleto ou músculos.

As lesões por overuse ocorrem isoladamente ou como resultados de stress nos músculos esqueléticos repetitivos, tais como ocorrem em treinamentos vigorosos e/ou atividades biomecânicas incorretas.

Pesquisa feita pela revista especializada Health Magazine reporta que 65\% dos profissionais de futebol americano sofrem alguma lesão relacionada com a profissão; comparada a $75 \%$ dos músicos profissionais. ${ }^{23}$

\footnotetext{
${ }^{23}$ Health Magazine, May/June 1993
} 
A corrente estatística a respeito dos problemas dos músicos profissionais é alarmantemente alta.

O Jornal New England de Medicina ${ }^{24}$ cita que $50 \%$ de todos os músicos profissionais sofrem de vários níveis de lesão muscular enquanto outros estudos dizem que estes dados são mais altos que $75 \%{ }^{25}$.

O rendimento, em esportes e atividades físicas, está intrinsecamente relacionado à "técnica". Somos "atletas" do instrumento e, de certa forma, esquecemos que nosso corpo também faz parte da performance e, como tal, deve ser devidamente "afinado".

No contrabaixo, instrumento em questão, exige-se mais de alguns grupos musculares que necessitam de atenção especial e devem ser treinados e condicionados a essas exigências.

É necessário, e incansavelmente afirmado por nós, que o músico entenda as partes de seu corpo e faça constante manutenção, tal qual se faz ao instrumento, periodicamente, para que produza melhores resultados, além do objetivo da melhor prática e execução instrumental.

No tema proposto, é indispensável a prática de algum esporte que vise a descongestionar tecidos e músculos, pela demanda de trabalho e da modernidade. Dessa forma, sugerem-se alguns esportes, entre várias modalidades, mencionadas em obra já citada da Professora Julie Lyonn Lieberman:

- Natação - por movimentar praticamente todos os músculos e articulações do corpo; por isso a natação é considerada um dos melhores exercícios físicos.

- Musculação - pelo conjunto de exercícios desenvolve e fortalece os músculos do corpo.

A respeito da musculação como prática esportiva, fica aqui um relato muito importante e pouco sabido entre os profissionais da área de música: o objetivo da musculação, dentre outros, é o trabalho da musculatura corporal, realizando exercícios contra a resistência que pode ser empregada das mais variadas formas,

\footnotetext{
${ }^{24}$ http://content.nejm.org/ acesso em julho de 2008.

${ }^{25}$ LIEBERMAN, July Lyonn. 3.ed., 1995 Revised.
} 
como uma carga num haltere ou numa barra longa, em aparelho com baterias de placas, tensores elásticos, aparelhos de ar comprimido, ou simplesmente contra a força da gravidade.

E devido à grande popularidade, boa parte dos musicistas tem praticado essa modalidade. Este pesquisador foi por muito tempo praticante da musculação, mas observou retrocesso na técnica com o instrumento. Essa foi, sem dúvida nenhuma, consequência da hipertrofia muscular - aumento do tamanho da fibra muscular em resposta ao treinamento, principalmente quando é do tipo contrarresistido, no qual o praticante exerce resistência contra a força da gravidade, contra os aparelhos ou halteres.

Essa hipertrofia pode ser temporária (apenas durante a prática dos exercícios) ou crônica (quando supera três ou mais dias sem atividade específica). Isso acontece, porque o corpo tem de recuperar-se do estresse sofrido e aumenta 0 tamanho da fibra muscular, a fim de suportar mais carga.

Com o aumento e a rigidez da massa muscular, fica prejudicada a musculatura usada para a execução do instrumento, atividade que muitas vezes necessita da flexibilidade, além da força. Como não há literatura sobre o assunto; muitas vezes desiste-se dos exercícios, para não provocar prejuízo ao trabalho com o instrumento. Em resposta a esse problema, sugere-se aos músicos exercitar com pesos leves, ou melhor, halteres e aparelhos com menos peso (carga). Outra opção é a prática de exercícios com mais repetições, em lugar de cargas pesadas. Sessões de alongamento e exercícios aeróbicos são também altamente recomendados, e o mais importante: permitir que corpo descanse, pelo menos um dia de repouso, entre os treinos, para dar ao organismo chance de se reabilitar.

Outras modalidades esportivas que trazem benefícios ao corpo humano, reiterada aqui a melhora de performance musical, são:

- Ginástica aeróbica - caracterizada por movimentos rítmicos e intensos com elevado gasto calórico e de impacto sobre as juntas, movimentos estes causadores de esforço físico que pode ser suprido pela oxigenação normal da respiração, quase sempre acompanhados de música, e que produzem aumento metabólico e uso de substratos benéficos ao organismo. Pode ser qualquer atividade física caracterizada pela prática de exercícios isotônicos, ou seja, esforços musculares em que existe a manutenção da tonicidade muscular, cujo comprimento e volume modificam-se com o tempo. Geralmente são 
exercícios em que não há exaustão por acúmulo excessivo de ácido láctico, o consumo de oxigênio pelo músculo é proporcional e, por conseguinte, o ganho anabólico é menor, quando comparado com os exercícios anaeróbios.

- Pilates - esse método consiste em mais de 500 exercícios em nove aparelhos com o objetivo de desenvolver o corpo harmoniosamente. Os exercícios são rítmicos, de força e alongamentos, e demandam concentração e controle do corpo. Em vez de repetições, o método requer que os exercícios sejam feitos com movimentos precisos. Muitos são baseados no Hatha Yoga: respiração profunda, meditação; e exercícios gregos e romanos. Indicado para reabilitação física, condicionamento físico geral e bem-estar, promove harmonia, flexibilidade e equilíbrio muscular. Por ser supervisionado por professor, é direcionado às necessidades de cada pessoa. Dessa forma, o Pilates pode ser praticado por pessoas de todas as idades e níveis de condicionamento físico. Além disso, traz como benefícios: a melhoria da concentração, coordenação motora e consciência corporal. ${ }^{26}$

Aliás, essa ginástica - desenvolvida por seu criador de mesmo nome Pilates a cada dia obtém mais adeptos, principalmente por não ser modalidade agressiva, ou seja, não há forte impacto para articulações e juntas. É, assim, muito indicada para músicos, pois é método de condicionamento físico que prioriza essencialmente centralização e simetria corporal, respiração, concentração, alongamento e tonicidade muscular.

- Tai Chi Chuan - arte marcial chinesa "nei chia" (interna), é conhecida pelos benefícios para a saúde e a longevidade. Também conhecida como arte marcial de estilo suave, aplicada como relaxamento mais completo possível da musculatura. Distingue-se pelas rotinas de movimentos lentos, pois o praticante é orientado a ter consciência do próprio equilíbrio, e como este é afetado; aprende ainda a apreciar os valores práticos da habilidade de moderar os extremos do comportamento e das atitudes em nível mental e físico, e como isso se aplica aos princípios de autodefesa.

A meditação, usada no Tai Chi Chuan, mostra-se muito eficaz na aplicação suplementar à música. Até porque meditar quer dizer ato ou efeito de concentração intensa do espírito; reflexão ${ }^{27}$, processo mental que muito contribui, além da saúde

\footnotetext{
${ }^{26} \mathrm{http} / / /$ www.copacabanarunners.net/pilates.html acesso em julho de 2008.

${ }^{27}$ HOLLANDA, Aurélio Buarque de, Dicionário da Língua Portuguesa.
} 
física. Essa concentração é muito importante na vida profissional do músico que tanto precisa de disciplina, memória e raciocínio lógico.

- Yoga - antiga filosofia de vida, que se originou na Índia há mais de 5.000 anos, por isso figura ainda hoje em todo o mundo como o mais antigo e holístico sistema para colocar em forma o corpo e a mente. Literalmente, significa união, pois integra corpo, mente e emoções; para isso induz a: profundo relaxamento, tranquilidade mental, concentração, clareza de pensamento e percepção interior com o fortalecimento do corpo físico e o desenvolvimento da flexibilidade.

A Yoga é ótima ferramenta para o instrumentista, em especial àqueles que não se sentem confortáveis em apresentar-se individualmente, situação para a qual os americanos adotaram a expressão stage fright - ansiedade, medo ou fobia persistente. Esse mal estar pode aparecer, quando o músico é individualmente requerido para tocar frente a uma platéia ou em testes para obter vaga de emprego; assim, esse descontrole é um desserviço ao potencial musical. Mediante esses problemas, a Yoga mostra-se satisfatória para minimizá-los e, até mesmo, eliminálos da vida do músico.

A expressão Stage Fright não tem uma tradução satisfatória para a língua portuguesa, por outro lado achamos melhor denominá-la como: medo de palco ou ansiedade de performance, que nos parece mais adequado, de modo que, em momento oportuno iremos estudar esses efeitos e como podem ser resolvidos.

Independentemente da modalidade, toda prática que beneficie a performance deve buscar a máxima latina: "mens sana in corpore sano".

Enfocaremos a partir de agora esse grande instrumento, nascido em uma época na qual não havia preocupação com ergonomia nem com o elevado grau de competitividade profissional, aliás, muito natural hoje.

Exemplo dessa dificuldade e da escassez de emprego, no mundo globalizado, para almejar uma vaga como membro de orquestra, é necessário executar dez ou mais trechos, dois concertos com movimentos contrastantes, além de uma peça de livre escolha. Para tornar essa performance possível, é claro que são exigidas muitas horas de dedicação, além de ser muito bem planejado. 
Nesse sentido, e esclarecendo ainda mais nossa problemática, manifesta-se o primoroso contrabaixista Ducan Mcatier ${ }^{28}$ : "Tocar contrabaixo é realmente exaustivo para o corpo, até mesmo para o mais dedicado contrabaixista, e provavelmente quatro horas de prática serão muito cansativas. Isso comparado com violinistas, violistas ou violoncelistas, que podem praticar mais de oito horas por dia, quatro horas para eles não serão demasiadas".

Em consequência de todos os argumentos já explicitados, torna-se imperioso seguir com o estudo da biomecânica e da anatomia, com o intuito de traçar e mapear o corpo humano de modo a ter consciência dos limites corporais e peculiarmente da característica do músculo-esqueleto ou da articulação, empregada no desempenho de tão imponente instrumento: o Contrabaixo Acústico.

A disciplina do músico instrumentista pode ser comparada a de um desportista; ambos reconhecem que o treino (a prática) é necessária para desenvolver força e flexibilidade.

Especificamente sobre o Contrabaixo Acústico torna-se indispensável a constituição muscular para tocar esse tão ingrato instrumento ${ }^{29}$, assim denominado pelo ex-professor do Conservatório de Paris, Jean Marc Rollez, talvez pelo fato de o instrumento impor limitações distintas de outros instrumentos, no que se refere a: projeção de som, repertório e dimensão do instrumento em seu manuseio.

\section{FACE PLANTAR (pés)}

Inicialmente faremos algumas considerações ao estudo da face plantar (fig.1), popularmente conhecida como sola do pé. Imagem comum, quando se pensa em um contrabaixista tocando é o indivíduo em pé, dedilhando o instrumento, o maior da família das cordas.

\footnotetext{
${ }^{28}$ MACTIER, Duncan. Tips and Tricks, Volume 1, Preparation and Pratice.

${ }^{29}$ ROLLEZ Jean-Marc, Méthode de contrebasse $n \circ 1$.
} 


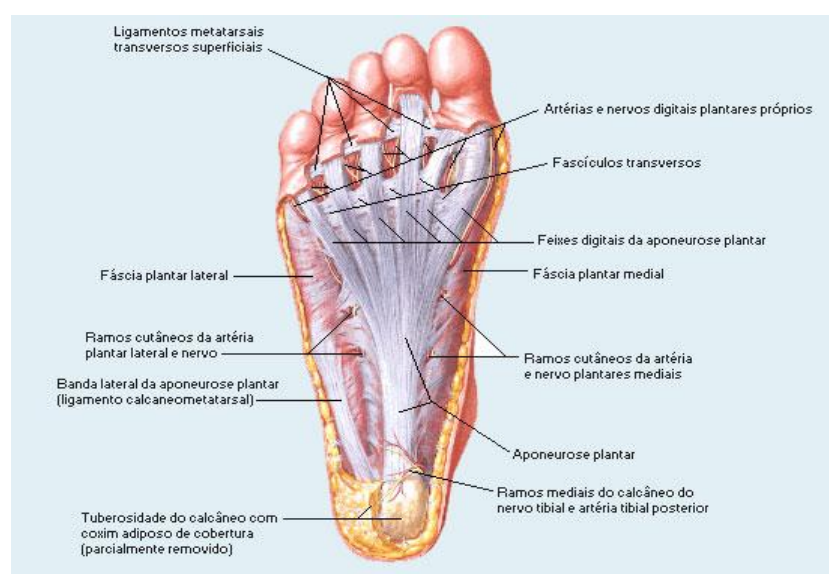

Fig.1. Face Plantar http://www.miologia.hpg.com.br/pe.html

A face plantar representa a base da reflexologia, técnica específica de pressão que atua em pontos reflexos precisos dos pés, com base na premissa de que as áreas reflexas dos pés correspondem a todas as partes do corpo.

O metatarso - que é a parte do pé entre o tarso e os dedos, é um grupo de cinco ossos que forma o arco plantar - situado entre o calcanhar e a sola do pé, tem a função de suportar todas as reações musculares relacionadas ao centro de gravidade corporal, especialmente quando andamos. Um exercício simples demonstra esse fenômeno:

Em pé, em posição relaxada, com os olhos fechados; pés juntos (calcanhares) e ombros alinhados com as mãos suspensas acima da cabeça: mova a cabeça em mais ou menos dez centímetros de forma circular. Essa rotação afetará todo o equilíbrio corporal, refletindo diretamente e provocando reação nos ossos de ambos os metatarsos, responsáveis pela estabilidade corpórea. Sem a atuação desses ossos não ficaríamos em pé - há alguns espasmos musculares nos pés quando se acomodam, para alcançar o equilíbrio corpóreo. Dessa maneira pode-se detectar qualquer tensão desnecessária e, de forma consciente, eliminá-la. ${ }^{30}$

Particularmente, foram anos para descobrir uma das causas de sentir fortes dores nos calcanhares. Por consequência disso, e sem exagero a esse tipo de situação, reafirmo a necessidade de profissionais da saúde especializarem-se e melhorarem seus conhecimentos sobre as lesões que podem ser provocadas pela má postura, principalmente no meio artístico.

\footnotetext{
${ }^{30}$ GOÏLAV, Yoan, The Double Bass - A PHILOSOPHY OF PLAYING, p. 54.
} 
O diagnóstico que obtive foi fasceite plantar que consiste na inflamação ocasionada por microtraumatismos de repetição na origem da tuberosidade medial do calcâneo. As forças de tração, durante o apoio, levam ao processo inflamatório, que resulta em fibrose e degeneração das fibras faciais que se originam no osso.

Segundo muitos especialistas, a resposta e a resolução para dor não solucionada estavam no metatarso. Quando o contrabaixo é tocado com a postura "em pé" (que mais adiante trataremos de forma específica), o peso corporal concentra-se nos pés e devem ser simetricamente distribuídos. Ocorre que o peso corpóreo deve ser distribuído em ambos os pés, nos metatarsos, e aliviar os calcanhares sem sobrecarregar a coluna.

\section{JOELHOS}

O joelho (fig.2) é o segmento do membro inferior que compreende a articulação da coxa com a perna e todas as partes moles (tecidos) que a circundam. Nossos joelhos devem estar sempre em postura relaxada, nunca tencionada, pois assim pode até produzir dificuldade para a respiração.

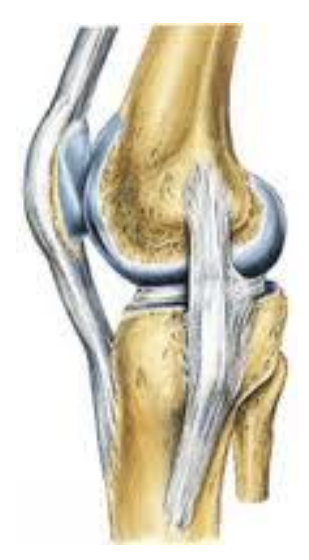

Fig.2. Joelho http://jeffregis.blogspot.com/2010/03/saiba-como-identificar-e-tratar-lesao.html

Proibida mesmo é a postura em que os joelhos mantêm a articulação "travada" ou em posição de "bloqueio", momento em que os ligamentos tendem a ficar tencionados. Em sentido contrário - a "posição frouxa" - consiste na frouxidão dos ligamentos, que é a melhor postura a ser adotada, pois colabora para a posição postural relaxada.

Em meados dos anos noventa recebemos uma lição muito importante do Prof. Hans Roelofsen, renomado professor holandês da New Dutch School, que 
apregoa a nova concepção para a performance em contrabaixo. Em aula, explicou a limitação dos movimentos de forma global, quando os joelhos estão em posição de bloqueio. Pediu que travássemos os joelhos e levantássemos uma cadeira sem flexioná-los. O resultado foi perda de força e amplitude dos movimentos (totalmente restritos), sem mencionar a tensão reflexa por todo o corpo. Portanto, a maneira de evitar ou diminuir possíveis tensões, a forma mais simples e objetiva, é sempre utilizar a postura frouxa em relação aos joelhos.

\section{PÉLVIS (bacia)}

A pelve (fig.3) (ou popularmente chamada de bacia) contém os principais componentes abdominais. Tem esse nome pela similaridade, ao sobrepor o desenho de uma bacia à região pélvica. $O$ esqueleto da pelve é formado por: ílio, ísquio, púbis, sacro e cóccix. ${ }^{31}$

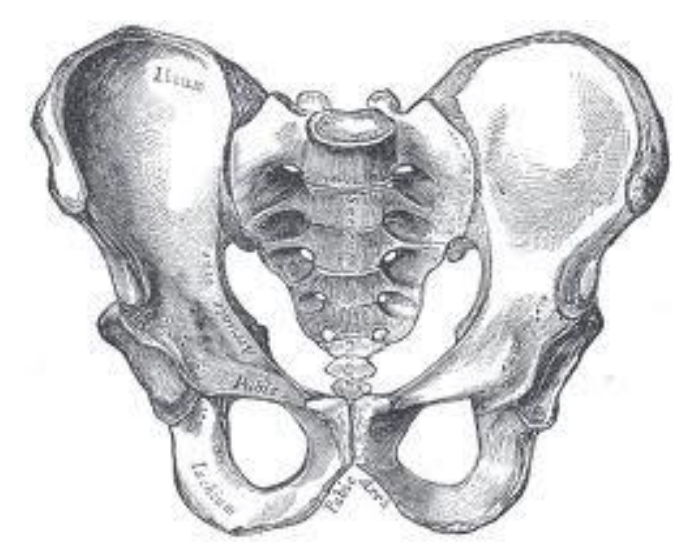

Fig.3. Pelve http://www.blog-medico.com.ar/noticias-medicina/emergencia/traumatismo-de-pelvis.htm

Em postura usual, tem-se a impressão de que o corpo é cortado em dois; pés e pernas - cabeça e tronco. Para aliviar e tentar evitar qualquer tipo de tensão é importante, tanto na postura em pé ou sentado, considerar que a proteção contra possíveis dores começa antes de assumir qualquer uma das posturas utilizadas para tocar o instrumento ora estudado.

Se o músico tocar sentado deve fazê-lo sobre os ísquios - ossos que constituem a zona inferior da pélvis (quadril) e que apóiam o corpo, quando estamos sentados e mantêm a coluna no alinhamento adequado.

\footnotetext{
${ }^{31}$ MANTAK, Chia. Exercícios Para Revitalização, Saúde e Longevidade.
} 
A coluna vertebral não é "reta"32 e, quando não há cadeira adequada (o que ocorre na maioria das vezes nas orquestras), o músico deve inclinar ligeiramente a parte do tronco para frente, o que será suficiente para equilibrar o centro de gravidade corporal. Na postura em pé, o processo é o mesmo: inclinar o corpo à frente, assim a massa corporal estará distribuída de forma mais uniforme, sem sobrecarregar a região da bacia.

\section{HARA - Centro do Abdome}

Hara é o centro da vida, situado no abdome (fig.4). Esse centro de energia corresponde ao centro de gravidade (ponto de equilíbrio físico) do ser humano, o abdome sem sombra de dúvidas é o centro de gravidade de nosso corpo, e influencia todos seus movimentos. Segundo os praticantes de Aikido, lá está a fonte de "energia", onde é concentrada boa parte de nossos órgãos vitais. Está também o diafragma, que é o músculo principal, responsável pela respiração humana.

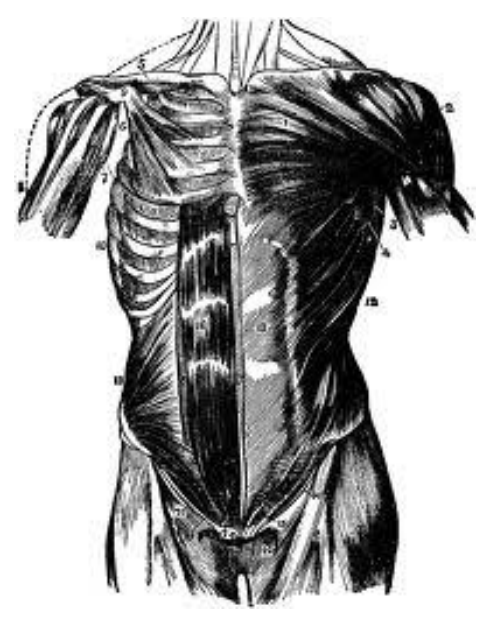

Fig.4. Centro do abdome (hara) http://etc.usf.edu/clipart/36900/36915/abdomen_36915.htm

Observado em artes marciais, como o Aikido, o abdome é responsável pela sustentação e pela saúde da coluna cervical. O mesmo raciocínio ocorre entre os praticantes de Pilates, no qual todos os exercícios devem começar pela conexão do transverso abdominal (músculo mais profundo, responsável pela sustentação e pela

\footnotetext{
${ }^{32}$ A coluna vertebral, quando vista de frente ou de costas, deve ser reta de ponta a ponta (observa-se no espelho). Quando vista de lado, normalmente a coluna apresenta três curvaturas: lordose cervical (voltada para frente), cifose dorsal (voltada para trás) e lordose lombar (voltada para frente), e quando alinhada mantém em boas condições os orifícios por onde saem as raízes nervosas. Alterações no alinhamento da coluna vertebral determinam postura inadequada, o que algumas vezes causa dor. (http://www.iafortopedia.com.br/orientacoes-para-pacientes/coluna/dor-nas-costas/)
} 
estabilização da coluna) com o assoalho pélvico (músculos localizados na região da pelve, responsáveis pela elevação das vísceras) através da respiração.

No baixo abdome, há contato direto com o instrumento e o som que ele produz, por isso devemos sempre ficar atentos ao contato com essa área, ou seja, o instrumento está apoiado nessa região em ambas as posturas: em pé ou sentado. 0 abdome recebe todas as vibrações e é capaz de receber os estímulos originados no próprio organismo ao que se dá o nome de proprioceptividade.

\section{COLUNA - Vertebral}

Em atenção às possíveis dores causadas na coluna cervical (fig.5), na maioria das vezes relacionadas com o overuse ou até mesmo o "carregar' o contrabaixo, ensina o Professor Carlos D. Fregtman:

Lembre-se de que sua coluna é como a corda de um instrumento... Afine-a, nem muito frouxa, nem muito tensa... sinta as plantas enraizadas no solo ${ }^{33}$. A coluna é formada pela sobreposição das vértebras desde o atlas, que é a primeira vértebra cervical que sustenta a cabeça até ao cóccix, que é o pequeno osso que termina a coluna vertebral na parte inferior e são responsáveis para o desempenho de uma boa posição postural.

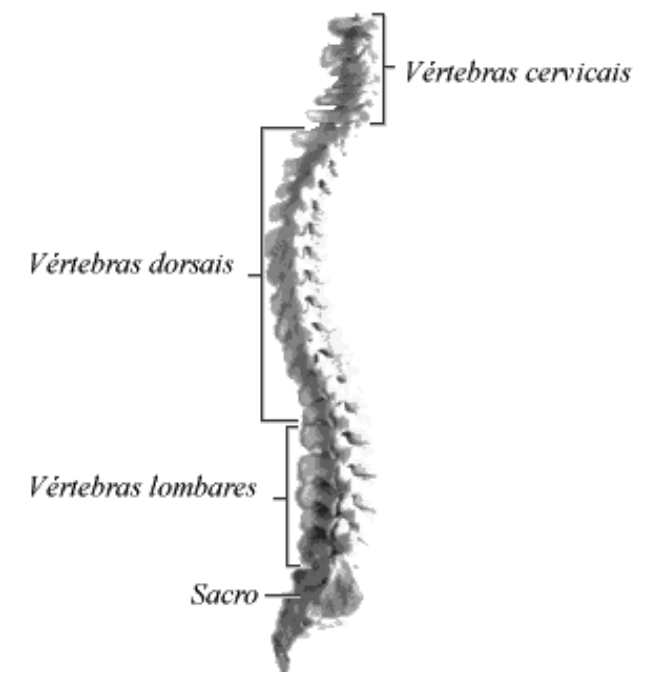

Fig.5. Coluna Cervical http://eli-espacoyoga.blogspot.com/2009/12/clouna-vertebral.html

A coluna dever estar pronta para "conversar" com nossa percepção sensorial e sistema motor ${ }^{34}$. Se for adotada sempre postura relaxada, evitam-se torções bruscas e, principalmente, realizar antes "alongamentos", o que propiciará as

\footnotetext{
${ }^{33}$ FREGTAMAN, Carlos D, 0 tao da Música, p. 95.

${ }^{34}$ Yoan GOÏLAV, obra cit. p. 56.
} 
conexões neurológicas responsáveis pelos movimentos. Não importa qual posição será usada para tocar o contrabaixo ou qualquer outro instrumento, essa parte do corpo, quando muito exigida, encontrará as dores relacionadas a ela.

O Professor Gary Karr, em relação ao desconforto provocado de forma inevitável pelo contrabaixo ensina: "em relação ao desconforto provocado na coluna pelo contrabaixo, principalmente quando tocado em posições agudas, é inevitável o que se pode fazer é no máximo minimizar essas consequências". Assim, ao tocar o instrumento, não se deve adotar posição estática, porque isso proporciona ao corpo sensação de peso, rigidez e tensão.

Uma boa solução para suavizar essas sensações de rigidez e desconforto é tocar o instrumento como se estivesse dançando. $O$ instrumento se tornará seu parceiro, é claro que de forma moderada, pois essa atitude proporcionará automassagem. Pelo mesmo preceito deve mexer a coluna de forma esguia, de forma simulada como se ela fosse uma cobra, movimentando-se de forma fluida e elegante.

\section{TÓRAX}

Essa parte do corpo tem relação direta com a forma de respirar. A cavidade torácica (fig.6) alberga a maior parte do sistema respiratório como também o coração. Todavia estão protegidos por armação óssea que liga o osso esterno, situado na parte anterior do tórax, e com o qual se articulam clavículas e cartilagens costais das sete primeiras costelas. A estrutura da caixa torácica é ligeiramente modificada, durante os movimentos respiratórios, por função dos músculos intercostais e do diafragma. 


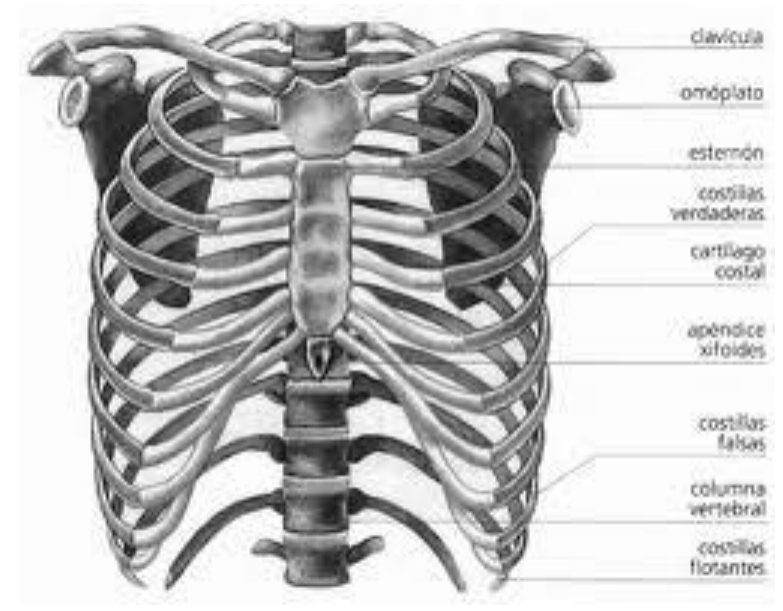

Fig.6. Cavidade Torácica

http://www.lookfordiagnosis.com/mesh_info.php?term=T\%C3\%B3rax+Fundido\&lang=3http://www.

Uma sugestão é que a caixa torácica deverá sempre estar confortável de maneira igual a nossa respiração, sem descuidar da postura.

\section{OMBROS}

Como estrutura anatômica, o ombro (fig.7) é estrutura complexa entre o braço e escápula; desse modo, a estrutura do tórax é constituída pela clavícula e pela escápula. Segundo o Professor Yoan Goïlav: "a função dos ombros é abrir caminho para fluir a energia emanada do hara (abdome) para os braços".

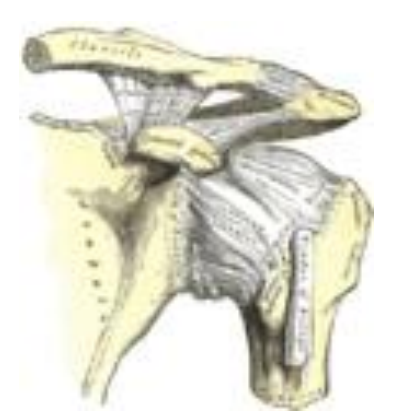

Fig.7. Ombro http://pt.wikipedia.org/wiki/Ficheiro:Gray326.png 
As mais comuns causas de dores nos ombros é a tendinite ${ }^{35}$. Em nosso caso, as dores nos ombros dos instrumentistas mais jovens estão geralmente relacionadas às atividades, ou seja, má postura, excesso de repetições, ausência de tônus muscular; ou, em casos extremos, o uso de instrumentos com regulagem de cordas muito altas, em relação ao espelho.

Por outro lado, dores após os 40 anos são relacionadas como degenerativas. O uso repetitivo dos ombros - ou até mesmo dos braços (que refletem também nos ombros) - causa redução de suprimento sanguíneo, o que resulta em inflamação e microscópicas rasgaduras nos tecidos, possibilitando o depósito de cálcio.

O tendão é uma fita ou cordão fibroso, formado por tecido conjuntivo, graças ao qual os músculos se inserem, nos ossos ou em outros órgãos; quando inflamado é comumente chamado de "tendinite". ${ }^{36}$

Inflamação da bursa (pequena bolsa com líquido, que envolve as articulações) funciona como amortecedor entre ossos, tendões e tecidos musculares. A bursa tem o efeito de almofada entre o músculo e o osso, e é responsável pela redução de friç̧ão entre os ossos, causada pelos movimentos, e torna a articulação mais flexível. Os locais mais afetados são: ombros, cotovelos, quadris e joelhos. Ela ocorre mais no ombro, devido à grande quantidade de bursas ali existentes. Nos ombros se dá pela inflamação da bursa subdeltoidiana que responde por mais da metade das dores, é denominada comumente como "bursite".

De modo geral, as inflamações nos ombros atingem pessoas que frequentemente usam braços e ombros, levantando-os em linha próxima ou acima da cabeça. Maestros, violinistas e percussionistas (fazendo menção a profissionais da música) são mais suscetíveis, pois as posições laborais exigem muito esses movimentos, por muitas horas diárias.

\footnotetext{
35 Os tendões correspondem à parte do tecido muscular que tem característica dura, flexível e fibrosa, responsável pela conexão dos músculos aos ossos, como um sistema de alavanca. Quando os tendões estão inflamados, irritados ou sofrem lesões microscópicas, leva à tendinite. Os tendões podem ser pequenos e delicados, como os dos músculos das mãos; ou grandes e pesados, como os dos músculos da coxa. Na maioria dos casos, a tendinite acontece por: excesso de uso (movimento repetido muito frequentemente) ou por sobrecarga (o nível de certa atividade, como o carregamento de pesos, tem sua frequência aumentada muito depressa). Dr. Mario César Prudente Leite, www.policlin.com.br/drpoli/123/

${ }^{36}$ HORVATH, Janet, Playing Less Hurt, Ed. 2009. P. 60.
} 
Em relação ao contrabaixo, para minimizar os efeitos mencionados nos ombros e uma possível lesão, os contrabaixistas devem virar o instrumento, quando for necessário tocar com o "arco" na corda sol, e sempre que possível evitar a rotação dos ombros.

Estatisticamente, contrabaixistas, que tocam com o arco próximo ao corpo, o que ocorre com frequência aos que utilizam o "Arco Francês", tendem a ter problemas com os ombros, como bursite. A solução adotada por muitos colegas tem sido trocar para o "Arco Alemão", que reduz satisfatoriamente a rotação dos ombros. $^{37}$

\section{Braços}

Dos ombros às pontas dos dedos, o braço (fig.8) tem seis articulações (juntas); ombros, cotovelos, pulsos e três juntas nos dedos. ${ }^{38} \mathrm{Em}$ sua estrutura anatômica esses músculos são primariamente responsáveis pelos movimentos das mãos, e estão localizados no antebraço. Manter alinhamento entre pulso e dedos e evitar sempre que possível flexionar ou travar o pulso - da mesma maneira como nos referimos aos "joelhos" - como resultado o instrumentista terá boa ação dos dedos, principalmente contrabaixistas, visto que as cordas do instrumento são as mais tensas do grupo de cordas.

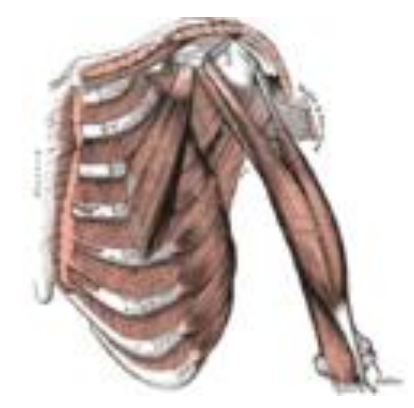

Fig.8. Braço http://pt.wikipedia.org/wiki/Ficheiro:Arm_muscles_front_deep.png

O fundamental é que todas essas articulações devem ser sempre ativadas de forma não tensionadas. Ao praticar um instrumento, não se deve esquecer esse conjunto tão importante, pois ele é responsável também pela produção do som.

\footnotetext{
${ }^{37}$ HORVATH, Janet. Obra cit. pg. 62

${ }^{38}$ GOÏLAV,' Yoan, obra cit. p. 56.
} 


\section{CERVICAL (nuca), PESCOÇO E MAXILAR}

Estes são um dos centros onde as tensões mais se concentram, o que por sua vez interfere na circulação sanguínea para o cérebro e, conseqüente, na concentração.

A coluna cervical (fig.9) localiza-se no pescoço entre a parte inferior do crânio e a superior do tronco, no nível dos ombros, é composta de sete ossos sobrepostos (as vértebras). Estas estão unidas por estruturas chamadas ligamentos, músculos e por elementos que preenchem o espaço entre elas - discos intervertebrais.

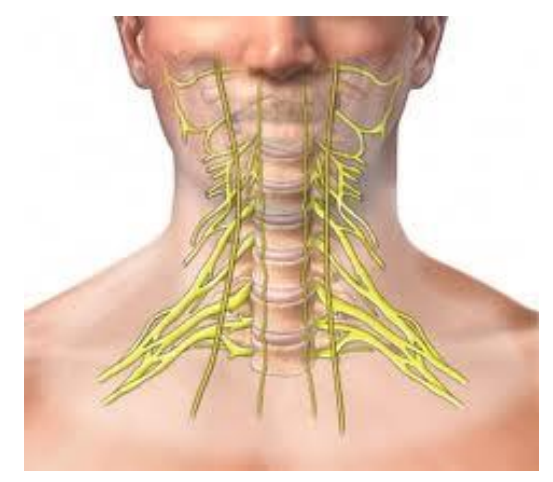

Fig.8. Coluna Cervical www.aurorahealthcare.org

O corpo humano mostra-se como constituição muito complexa; e o alinhamento, como unidade. A coluna cervical, comumente chamada de "nuca", precisa manter-se alinhada com os ombros, ou seja, deve-se imaginar que as orelhas estão alinhadas com os ombros para evitar: torções, tensões e movimentos bruscos. Qualquer postura que coloque a cervical ligeiramente adiante ou atrás do corpo provocará seu estiramento.

O alongamento é fundamental nessa área do pescoço, tanto antes quanto depois da prática ou performance. $\mathrm{O}$ indivíduo que possui tiques, como morder a língua, enquanto executa obra musical ou estuda, é exemplo de fácil constatação de tensão no maxilar, tencionando grande parte dessa área. Um maestro famoso que esteve à frente de grande orquestra brasileira, possui esse tique: "morde" constantemente a língua, seja em ensaios ou concertos. Essa postura em contrair o maxilar e, por consequência, a língua, desenvolve a força de $55 \mathrm{~kg} / \mathrm{cm}^{2}$ nos incisivos, os dentes cortantes, e mais de $80 \mathrm{~kg} / \mathrm{cm}^{2}$ nos molares. 
Desse modo, é necessário policiar-se em relação à atitude de tencionar essa região, que só traz malefícios ao corpo, bem como interferem na performance. Assim, a sugestão é não tencionar qualquer parte entre pescoço, maxilar e cervical.

Assim, quando necessário flexionar o corpo para frente ou trás, o músico deverá usar a pélvis como pivô e nunca deixar a cervical ligeiramente à frente ou atrás do corpo.

POSIÇÃO POSTURAL - (maneira como se segura o instrumento)

- Segurar o instrumento na posição em pé

Existem várias maneiras de executar o contrabaixo acústico. Essas variantes são atribuídas a aspectos culturais, regiões geográficas e peculiaridades individuais de seus expoentes. A execução do contrabaixo acústico com arco não é uniforme, como já mencionado. As variantes: peculiaridades dos músicos, execução em pé ou sentados, altura dos bancos, arco francês ou alemão, implicam nas distintas posturas em que articulações e músculos são mais ou menos exigidos.

É imperioso ressaltar as diversas metodologias acerca da posição postural, em relação ao instrumento, pois um método pode contradizer outros.

É claro que não é alterada a forma básica como o instrumento produz sons, mas sim a forma como o intérprete produzirá. Na literatura do instrumento, no que se refere aos métodos de execução; em realidade a maioria é datada de quase duzentos anos atrás; a postura "em pé" é sempre realçada nos métodos de contrabaixo acústico.

O Professor Gary Karr, em seu vídeo educacional intitulado: Bassikally Karr, comenta que segurar o instrumento é uma das tarefas mais difíceis para o contrabaixista, e alguns deles ficam até décadas, trocando a forma de segurar o instrumento, por não se sentirem confortáveis com a postura.

É evidente que muitos fatos exteriores contribuem para essa dificuldade postural. O grupo étnico e o fenótipo do executante, em nosso entendimento, são causa determinante para essa inadequação, pois o contrabaixo acústico não tem construção uniforme e até mesmo as medidas - normalmente consideradas padrão (3/4, 7/8 e 4/4) - mudam de forma expressiva de um fabricante para outro, ou seja, 
como na maioria dos instrumentos musicais, obrigatoriamente deve haver adequação por parte do músico. Assim, um indivíduo muito baixo, ou até mesmo muito alto, braços curtos, encontrará dificuldade por muitos anos até encontrar a posição cômoda que atenda às necessidades técnicomusicais. Igualmente, o professor do músico em questão deve ajudar o estudante a encontrar a postura que atenda o aluno, nunca de forma impositiva (o que na maioria das vezes não ocorre).

Contudo, antes de tecer comparações com os diversos tipos de posturas com o instrumento em pé, relataremos alguns detalhes sobre o centro de gravidade e estabilidade.

A estabilidade é definida como a capacidade de um objeto retornar ao equilíbrio ou à posição inicial, após ser deslocado. Para isso há diversos fatores, tais como: altura, tamanho da base de suporte. A estabilidade é imprescindível até mesmo para que não aconteça acidente de ordem física ou com o instrumento.

Uma solução fácil para a estabilidade em questão é a possibilidade de controlá-la mudando de postura ou posição como um "boxer" - assumir posições distintas, tanto para atacar quanto para bloquear o ataque. Ou seja, pés afastados com a base do pé direito ou esquerdo à frente com uma distância média de vinte centímetros.

O centro de gravidade, como é chamado de forma técnica (centróide de massa ou centro de massa), pode ser definido pelo ponto no qual a totalidade da massa corporal está igualmente distribuída. É claro que o centro de gravidade possui profunda relação com a estabilidade, significando que as forças e os torques gerados por ela estão plenamente equilibrados. Um fato significante, a posição vertical varia de indivíduo para indivíduo, e como a distribuição de massa corporal não é homogênea, o centro de gravidade é deslocado onde houver mais massa.

Com isso, a partir deste ponto observaremos distintas formas de segurar o instrumento, com os respectivos comentários e os expoentes de forma comparativa, referente à metodologia, como também vantagens e desvantagens em adotar a postura em pé.

Franz Simandl (1840-1912), foi professor, contrabaixista e autor do livro intitulado New Method for Double Bass, cuja primeira publicação data de 1881, tem sido usado em todo o mundo por estudantes e, provavelmente, mais do que 
qualquer outro método de contrabaixo ${ }^{39}$. Nesse método de contrabaixo, a postura ensinada é em pé e influenciou a maneira postural de muitos contrabaixistas tais como; Ludwig Streicher ${ }^{40}$, Gary Karr, Hermann Reinshagen ${ }^{41}$ entre outros.

A posição postural, adotada por Simandl, é a seguinte:

1.Com contrabaixo posicionado na forma vertical (não inclinada), em pé em frente ao cavalete do contrabaixo. 2. Dessa forma, com os braços em forma relaxada ao lado do corpo, as mãos devem encontrar o cavalete na altura das falanges dos dedos da mão esquerda; assim, a altura do contrabaixo estará perfeita. ${ }^{42}$ (fig.11) 3. Antes mesmo de tomar o contrabaixo em suas mãos, você deverá pensar na própria postura. Posicione os pés afastados aproximadamente em $38 \mathrm{~cm}$, de forma lateral; então, distribua seu peso corporal de forma homogênea sobre os dois pés, buscando a estabilidade. (fig. 10)

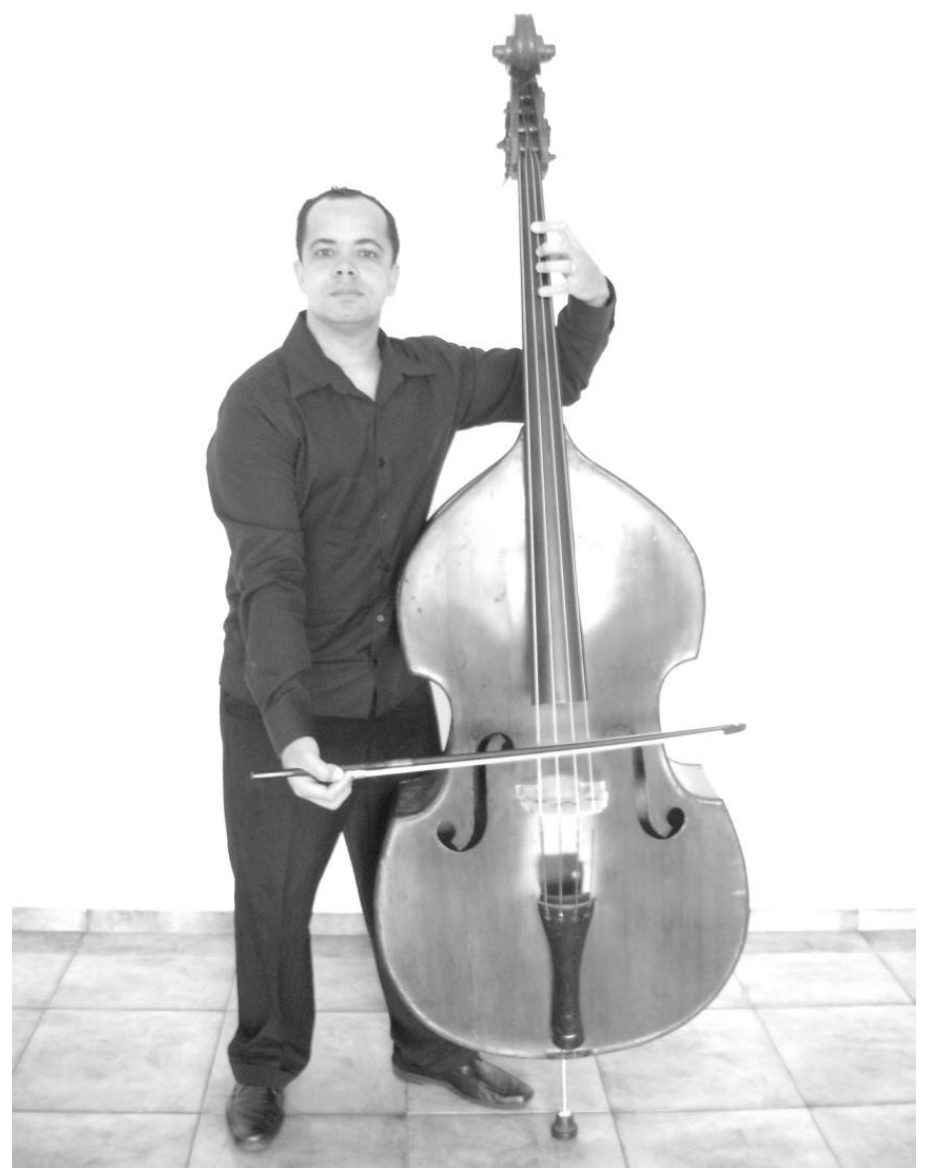

Fig.10. Postura Simandl

\footnotetext{
${ }^{39}$ SIMANDL, Franz. New Method for String Bass, revised and edited by Stuart Sankey, preface.

${ }^{40}$ STREICHER, Ludwig, (20.06.1920 - 11.03.2003), foi 10 contrabaixista da Orquestra da Filarmônica de Viena, autor de 5 volumes dos livros; My Way of Playing the Double Bass, renomado professor Vienense.

${ }^{41}$ Contrabaixista da Filarmônica de Nova York e professor do Institute of Music Art, atualmente Julliard School of Music.

${ }^{42}$ KARR, Gary, DoubleBass Book 1․․
} 
Outra metodologia é exposta pelo Professor Húngaro de contrabaixo Montag Lajos, em seu livro; Double - Bass Method, no qual apresenta aplicação interessante para a posição postural:

A altura do instrumento deverá ser ajustada com o corpo do músico, de modo que o instrumentista ao olhar para o contrabaixo tenha a pestana ${ }^{43}$ (que fica na voluta) na mesma altura dos olhos. O peso do corpo deverá repousar sobre o pé direito, o pé esquerdo deverá estar à frente a meio passo com o instrumento inclinado e apoiado ao joelho e pelve esquerda. $O$ músico deverá adotar sempre a posição ereta até mesmo quando toca nas regiões médias do instrumento. ${ }^{44}$ (fig. 12 e 13)

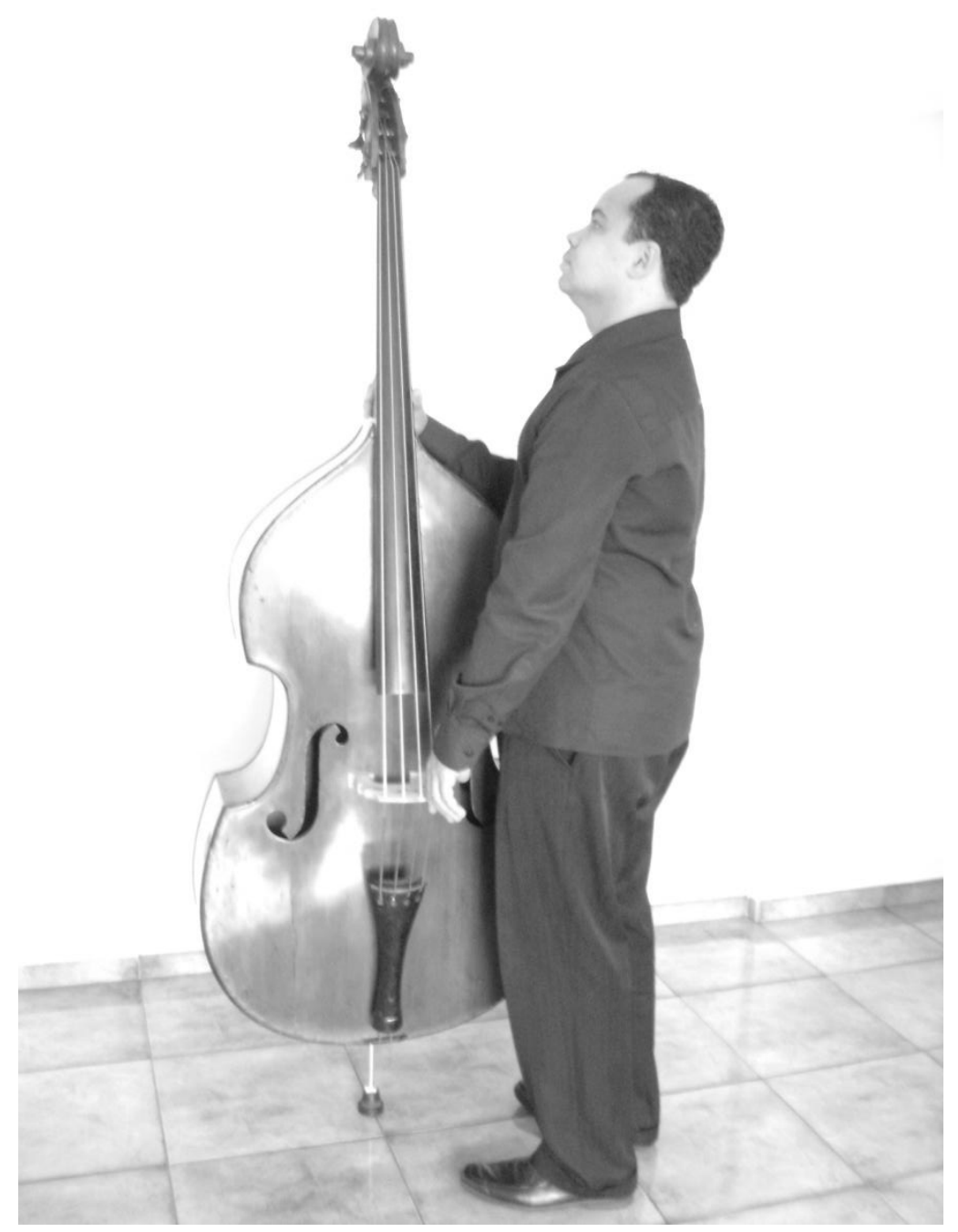

Fig.11. Altura do Instrumento (KARR, Gary, DoubleBass Book 1ㅇ, p.12)

\footnotetext{
${ }^{43}$ Nos instrumentos de cordas, pequeno filete, de madeira ou de marfim, próximo ao cravelhal, e sobre o qual as cordas passam a igual distância. Dicionário Aurélio, versão eletrônica.

${ }^{44}$ MONTAG, Lajos. Double Bass Method, p. 12.
} 


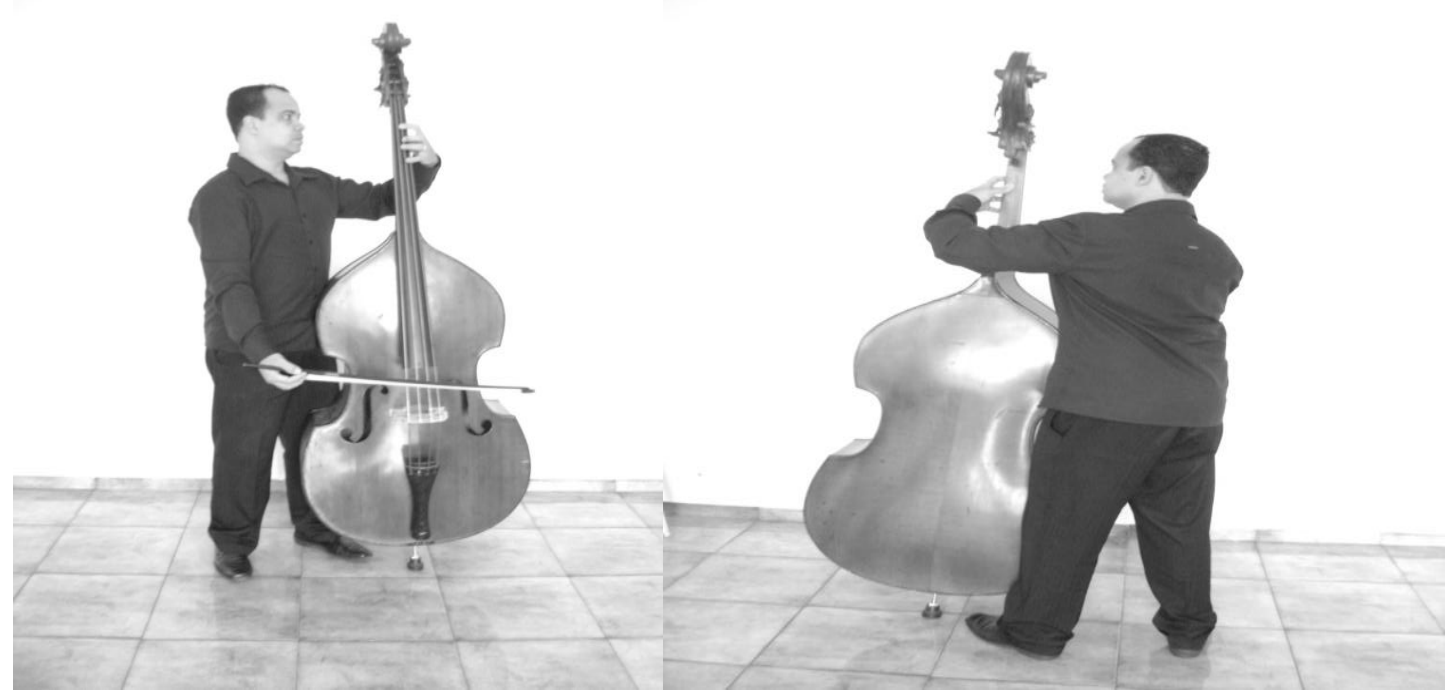

Fig.12 e 13. Atuação na região média do instrumento

Isaia Billé, em seu Nuovo Metodo per Contrabasso, de forma semelhante as já mencionadas, diz que o estudante deve se posicionar ligeiramente à frente, mas não muito, de forma que o lado esquerdo de seu corpo "descanse" levemente contra a parte superior direita do instrumento. O pé esquerdo deve ficar de modo oblíquo, meio passo a frente; dessa forma o joelho fica ligeiramente apoiado na parte lateral direita do tampo traseiro (o pé esquerdo não fica atrás do instrumento) ${ }^{45}$. (Fig.14 e 15)
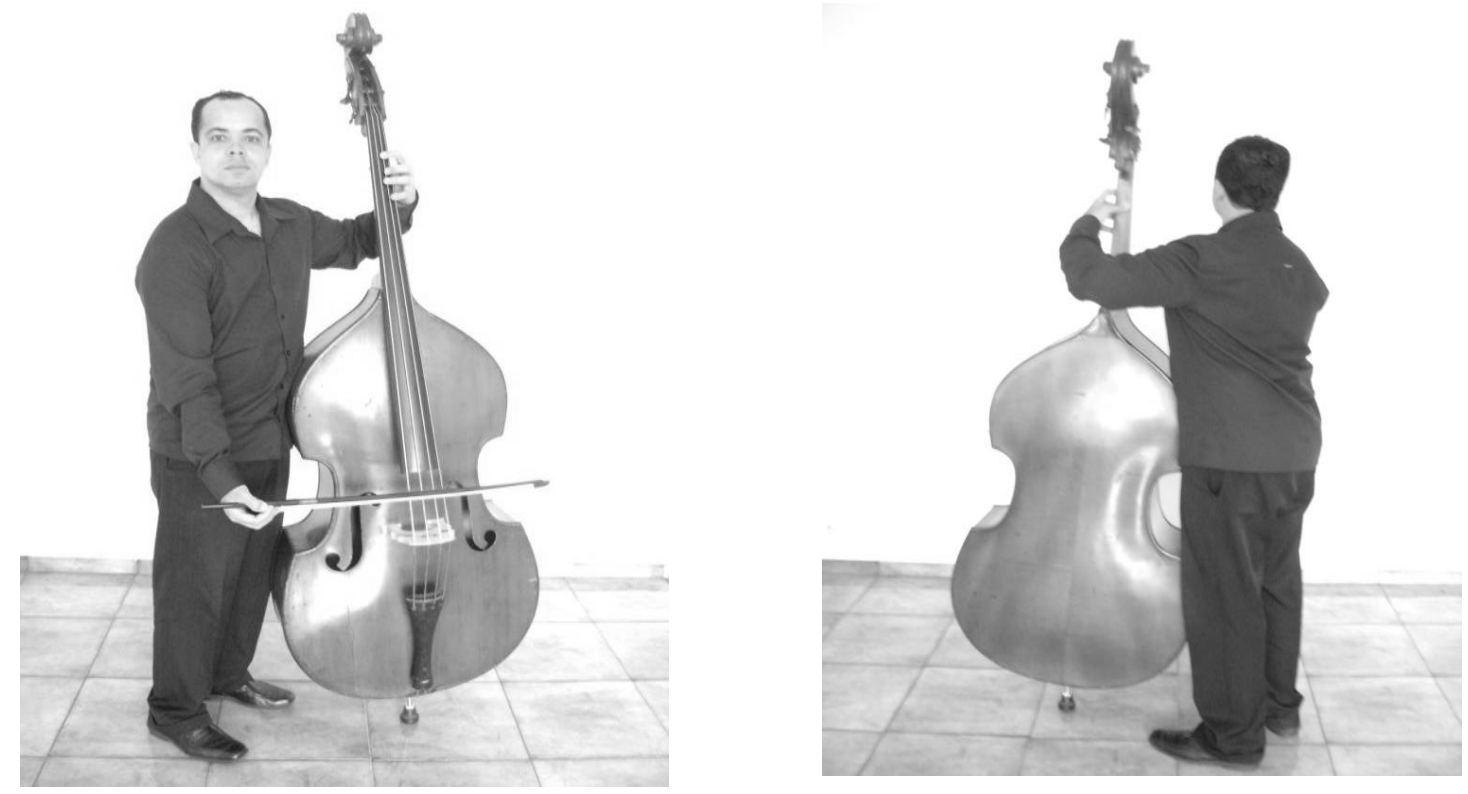

Fig.14 e 15. Pé esquerdo em posição oblíqua

\footnotetext{
${ }^{45}$ BILLÈ, Isaias, Nuovo Metodo per contrabasso, p. VII
} 
Ludwig Streicher, em seu livro My Way of Playing the Double Bass, diz que a altura do instrumento deve ser regulada pelo espigão de suporte ${ }^{46}$, dependendo da altura do contrabaixista, e o melhor caminho para obter bons resultados posturais é regular o instrumento de modo que a pestana fique à altura dos olhos, (observa-se que o professor adota o mesmo princípio que o professor Lajos Montag), pois defende que essa atitude em relação à postura diminuirá a tensão e possíveis problemas no pescoço e coluna. ${ }^{47}$ Essa forma de tocar o instrumento é peculiar: o contato do instrumento se dá pela virilha tocando a parte traseira do instrumento e lateralmente com o meio do abdome (Fig.16, 17 e 18). O Professor Streicher coloca o pé esquerdo levantado e apoiado na base inferior do tampo traseiro suportando 0 peso do instrumento entre o pé erguido e o joelho. Dessa maneira, o contrabaixo comprimirá o instrumento contra os dedos, pois o peso do instrumento em sua grande parte está sobre o pé direto o qual é ligeiramente flexionado para a direita.

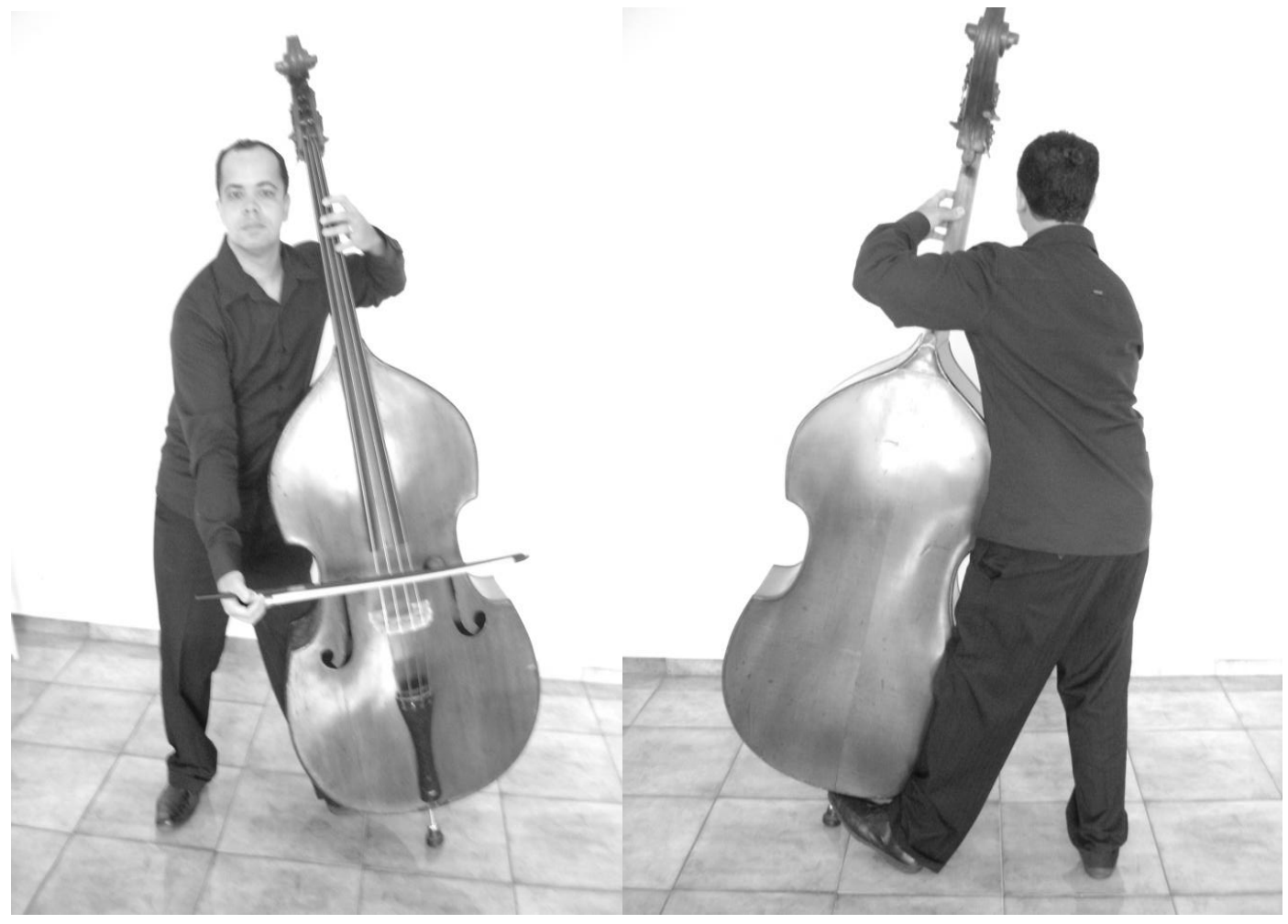

Fig.16

Fig.17

\footnotetext{
${ }^{46}$ Peça geralmente construída de metal ou madeira que suporta o peso do instrumento no chão e também é responsável pela altura do instrumento em relação ao músico por ser regulável.

${ }^{47}$ STREICHER, Ludwig, My way of playing the Double bass, Vol. 1
} 


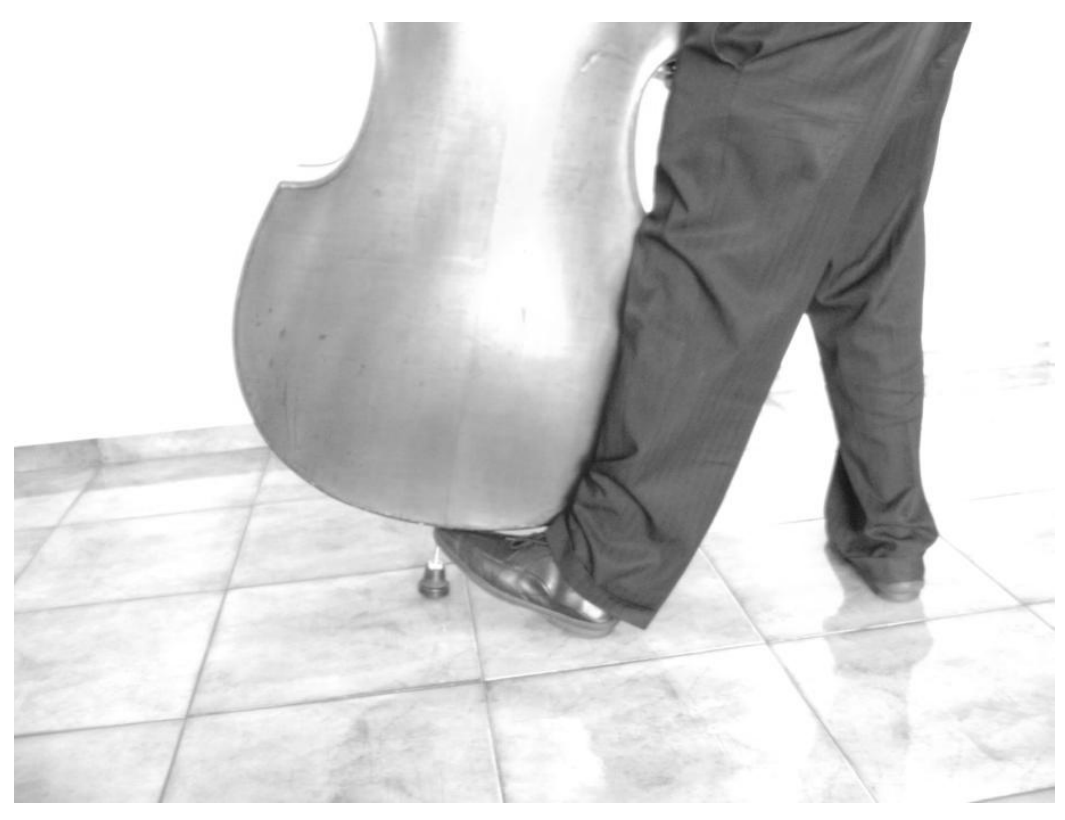

Fig. 18

É notório que as posturas acima dispostas comportam variações, mas são as mais utilizadas pelos músicos.

A seguir, e não desmerecendo o método utilizado pelos ilustres professores, adicionaremos comentários críticos sobre os procedimentos técnicos empregados já exemplificados:

No método Simandl, o mais utilizado em todo planeta como método introdutório de aprendizado no contrabaixo, há problemas de ordem prática. Com a altura do instrumento, regulada em conformidade com a altura, de modo que encontre os dedos da mão esquerda, vislumbro problemas. Nas partes graves do instrumento, ou seja, a partir da $1 \frac{1}{2}$ posição, a execução será prejudicada, pois a mão esquerda poderá ficar acima da cabeça do instrumentista; por outro lado, essa maneira de segurar o instrumento privilegia a execução das notas na região aguda do instrumento.

O benefício da postura "Simandl" de forma vertical traz a vantagem de o peso do instrumento estar "totalmente" direcionado no "espigão". Esse é o maior benefício, pois o peso do contrabaixo não será depositado contra o corpo do músico tampouco exercerá pressão sobre o polegar da mão esquerda; por esse mesmo raciocínio não provocará pressão alguma contra o corpo do músico. Gary Karr, 
grande expoente e um dos maiores responsáveis pela popularização do instrumento como solista, adota e defende a postura em questão.

Lajos Montag tem método similar à postura Simandl, porém com algumas alterações. A principal é a altura do instrumento, determinada pela altura da pestana em relação à dos olhos do instrumentista, (ambas devem estar na mesma altura). De maneira inversa essa metodologia trará mais facilidade em execução junto à região grave, pois a amplitude dos movimentos da mão esquerda não fica restrita e é obtida sem nenhuma torção ou desconforto. Contudo ficam prejudicadas as regiões agudas, pois - a depender do tamanho do instrumento e da altura do executante não serão facilmente alcançadas; assim, um recurso muito utilizado para alcançá-las é dar meio passo lateral com o pé direito (Fig.19) e dessa forma o instrumento recairá sobre o ombro esquerdo, o que possibilita acesso a essa região.

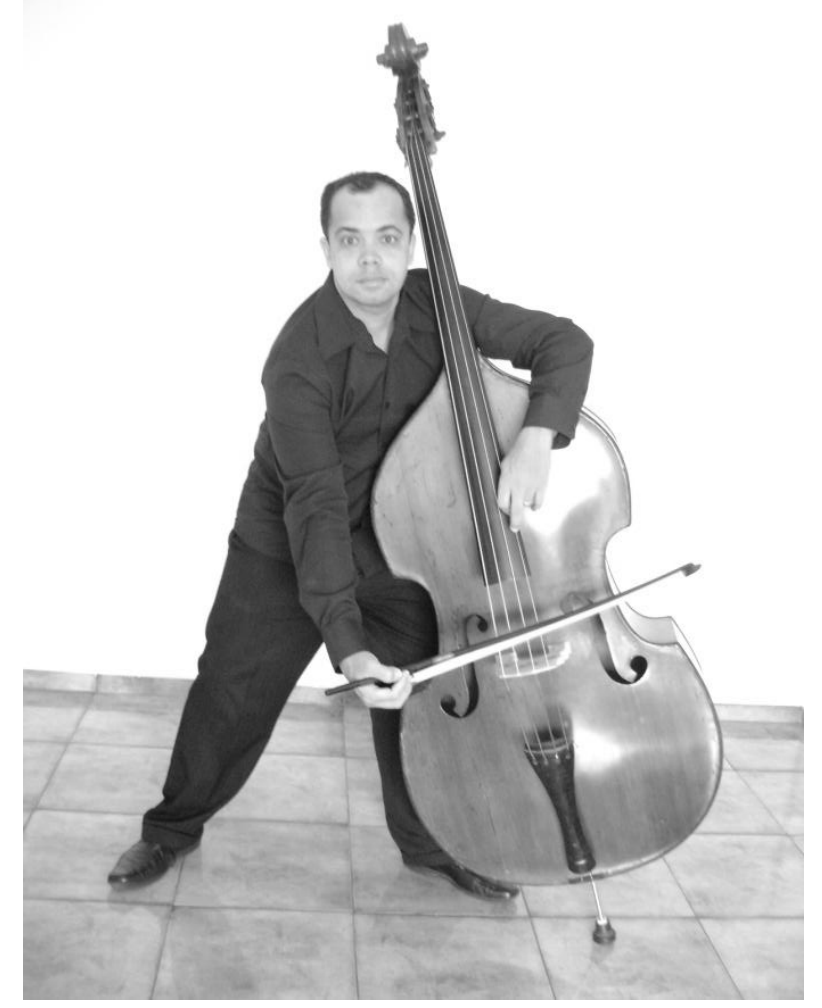

Fig. 19. 
O ponto mais negativo dessa postura é que o executor terá de estudar e aprender o instrumento com duas posturas diferentes; uma para tocar as notas graves e outra para tocar as agudas. (Fig.20)

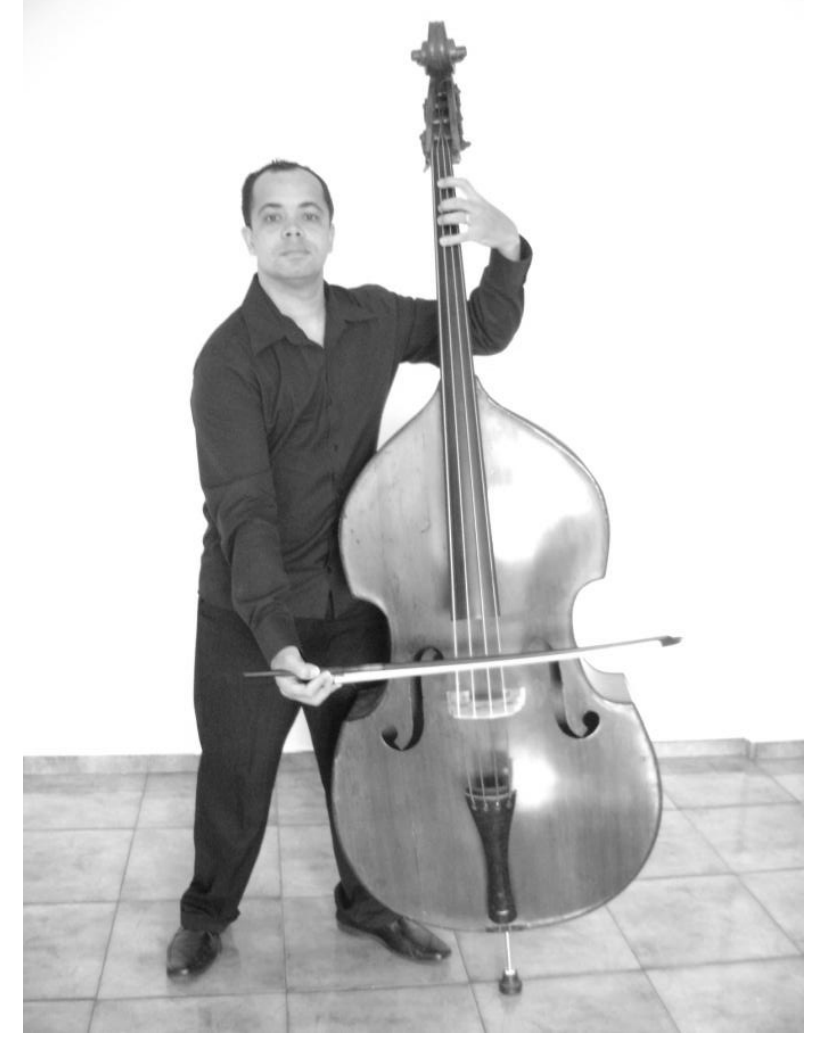

Fig.20

Isaia Billé, contrabaixista e professor, muito contribuiu para a literatura de nosso instrumento. Sua maneira de segurar o instrumento deveria ser muito próxima da postura adota por Simandl. Seu livro, Nuovo Metodo per Contrabasso, não dispõe fotos, o que impossibilita fazer juízo critico; por isso, optamos pela remissão ao que foi dito sobre a posição Simandl. Com a única diferença de que os pés não ficam atrás do instrumento; pelo fato de o professor usar o arco francês, consideração que será demonstrada em parte específica do estudo.

Outra variação do método adotado por Franz Simandl é como toca o Professor Ludwig Streicher, ex-professor da Academia de Viena.

Em realidade assemelha-se com a maneira mais próxima de segurar 0 instrumento de Lajos Montag, pois a pestana fica à altura dos olhos. Ressalta-se antes mesmo de fazermos considerações críticas a respeito da posição postural do Professor Streicher. Pode-se dizer que, de todos os autores examinados de forma comparada, é o único que detém registros fonográficos (gravações) além de seus 
livros didáticos; My Way of Playing Double bass em 5 volumes, ótimas referências aos estudantes do instrumento.

Entretanto observa-se a flexão dorsal do pé direito (fig.) de natureza contínua, durante a execução do instrumento. É claro que a justificativa para essa postura é que diminui de forma expressiva a tensão na mão esquerda, pois alivia o peso do instrumento, ou seja, a inclinação do instrumento fará que seu peso recaia diretamente na mão esquerda, quando executadas as notas graves no instrumento; por outro lado, considerada a execução nas notas agudas, não haverá o problema da mão esquerda, pois o peso do instrumento será depositado no ombro esquerdo.

Em consideração à flexão dorsal do pé esquerdo, achamos totalmente desnecessário. Isso se deve ao fato de a postura estressar ossos e músculos do pé esquerdo e depositar todo o peso corporal em cima do pé direito. Assim, é muito comum observar contrabaixistas que tocam em pé assumirem a posição acima descrita em desnível, em relação aos ombros, provocado pelo encurtamento dos tendões: o ombro direito, com o tempo, fica ligeiramente inclinado de forma mais baixa em relação à altura do ombro esquerdo.

Assim, refere-se o Professor Warren A. Benfield ${ }^{48}$ :

A estabilidade do corpo é vital para tocar Contrabaixo Acústico. Se a totalidade do peso corporal estiver apoiado apenas no pé direito, não haverá peso para apertar as cordas com a mão esquerda. Se o instrumentista toca em pé, ou até mesmo sentado, o peso deve ser distribuído em ambos os pés. Assim, o músico poderá mudar o peso, quando necessário, para a mão direita ou para a esquerda. Com essas considerações o músico deverá inclinar o contrabaixo contra o abdome, neste sentido, o instrumento ficará equilibrado, e assim, será de grande ajuda para a mão esquerda, pois; libera a tensão e conseqüentemente haverá uma melhoria técnica relação ao vibrato e mudança de posições.

\section{POSIÇÃO POSTURAL}

- Segurando o instrumento na posição sentada

Segurar o instrumento de forma sentada é historicamente a mais adotada, como é o caso do contrabaixista e compositor Domenico Dragonetti (Fig.21). Esta assertiva é de fácil constatação, pois o violoncelo, parente próximo do contrabaixo em relação a tamanho e proporcionalidade, é tocado de forma sentada. Na maioria

\footnotetext{
${ }^{48}$ BENFIELD, A. Warren, The Art of Double Bass Playing
} 
dos métodos e livros de estudo do contrabaixo quase nenhum autor leciona o instrumento de forma sentada.

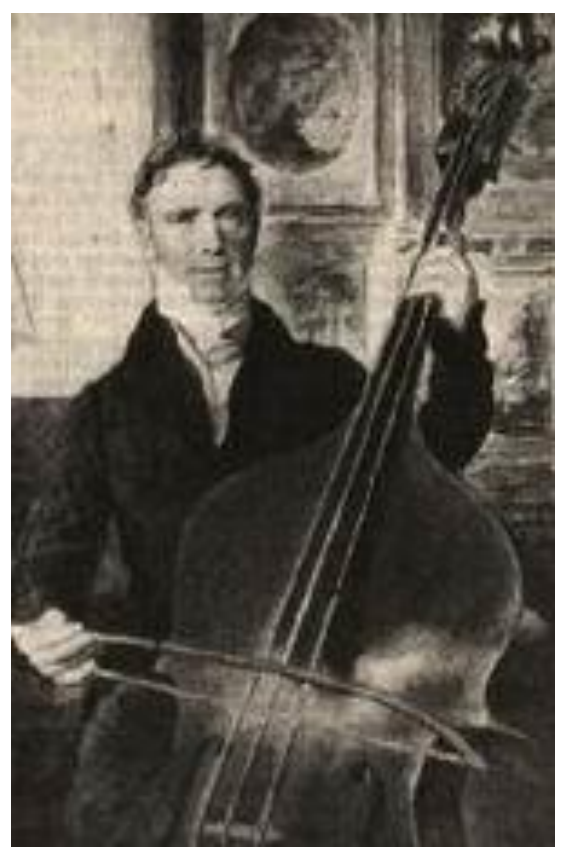

Fig.21. Posição sentada http://www.absoluteastronomy.com/topics/Domenico_Dragonetti

Acontece que, em meados do século XIX, pela necessidade de grandes grupos orquestrais e até mesmo por exigências composicionais, os contrabaixistas atuavam em grupo e, dependendo do trabalho, poderiam ficar em pé até seis horas em uma única apresentação; A ópera Siegfried de Wagner é um exemplo. A posição sentada, para quem toca contrabaixo e trabalha em orquestras ou pequenos grupos, é a mais acertada, com o propósito de evitar fadiga muscular, como também problemas circulatórios.

Porém há relatos isolados de algumas orquestras ainda resistirem à mudança e obrigarem o naipe de contrabaixo a tocar em pé, como é o caso da Orquestra do Estado de Kassel, que de forma obstinada continuou a tocar em pé até meados dos anos 80 .

Contudo a forma como os músicos assumem a posição postural sentada, tanto para o trabalho coletivo em orquestras sinfônicas, grupos de jazz e similares não é homogênea por aspectos geográficos, metodológicos e culturais.

Assim, alguns instrumentistas usam a cadeira ou banco para assumir a postura sentada, outros tocam sempre em pé, e até mesmo os que assumem a postura em conformidade com o tipo de música a ser executada. 
Muito comum é o contrabaixista que apenas consegue tocar seu instrumento de forma satisfatória, ou em pé ou sentado. Na prática observamos que o músico que apenas toca sentado encontra dificuldades para tocar em pé. Essa dificuldade é devido à falta de força dos músculos que constituem a região lombar. Isso se dá pelo fato de o músico que toca em pé exercitar de forma natural essa musculatura. No entanto, para o músico que toca em pé, assumir a posição sentada é com frequência mais fácil, além do fato de ser mais natural que a primeira.

É muito comum, o instrumentista que toca em pé, quando faz performance como solista, permanecer sentado, durante longos ensaios de orquestra e nos concertos. $^{49}$

Tal qual a posição em pé, a postura sentada apresenta algumas maneiras adotadas usualmente, em especial em orquestras sinfônicas. Diferentemente da forma ensinada por Simandl, a maioria dos instrumentistas (ao menos os que tocam em pé) tentam executar o instrumento de modo que ele fique com angulação similar a postura em pé (fig.22). Em geral nunca houve preocupação com a saúde postural do músico, fato este muito recente com relação ao Brasil.

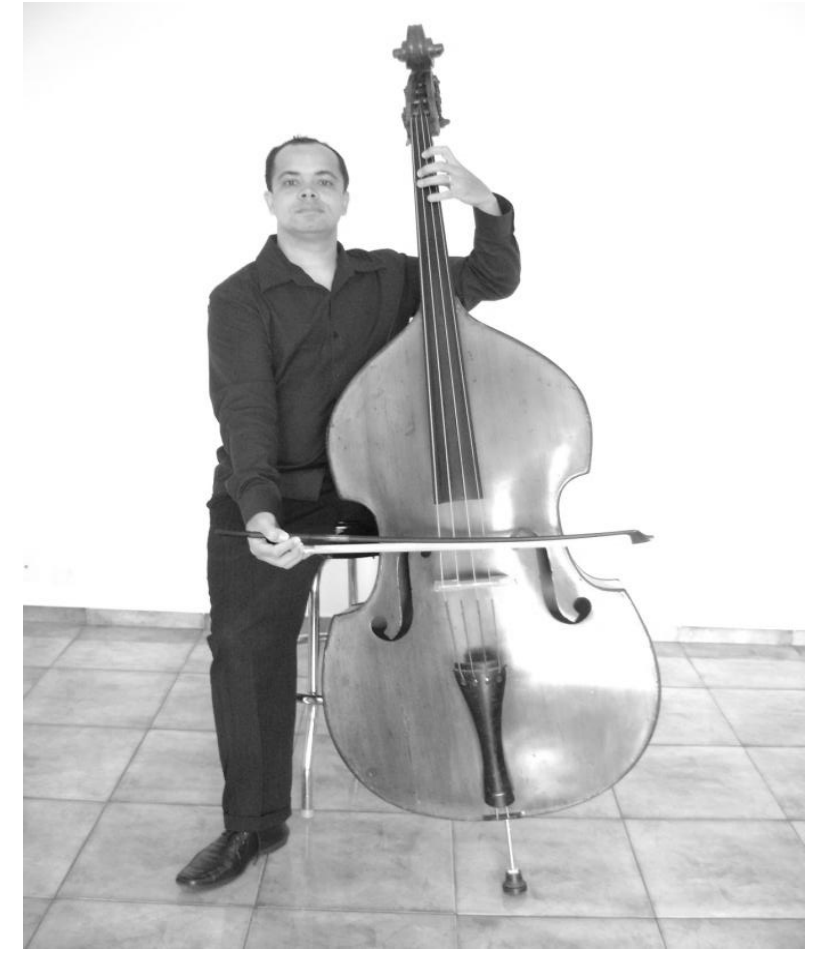

Fig.22.

\footnotetext{
${ }^{49}$ MORTON, Mark, Double Bass: Concept and Ideas, p. 1.
} 
Contrários às exigências da Orquestra do Estado de Kassel, em que frequentemente os contrabaixistas tocavam todos em pé, hoje são utilizadas nas orquestras brasileiras cadeiras não específicas para a profissão de músico, ou seja, construídas para outro fim. Do tipo "giroflex" (Fig.23), construídas com objetivo primário de uso para balconistas e arquitetos, não são apropriadas para acomodar um músico em média de 3 horas ou mais em sua atividade laborativa.

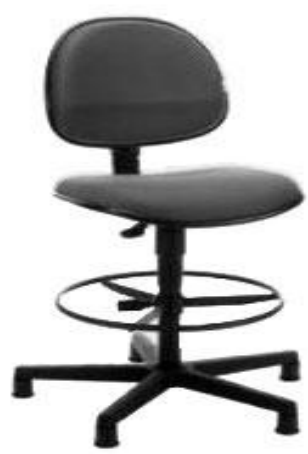

Fig.23. Cadeira Giroflex

O músico contrabaixista geralmente costuma sentar na ponta do assento, apoiando o pé esquerdo no suporte (muito comum nesse tipo de cadeira) e com o pé direito ancorado ao chão. $O$ contrabaixo, nessa posição, recai geralmente sobre a perna esquerda cujo joelho encosta na parte do tampo traseiro do instrumento.

É fato que, na atualidade, existem cadeiras profissionais projetadas com a finalidade ergonômica específica para tocar contrabaixo (Fig.24, 25 e 26), o que infelizmente ainda não é a realidade brasileira. Essa problemática está relacionada a um mercado muito estreito, com valor pecuniário inexpressivo para investimentos.

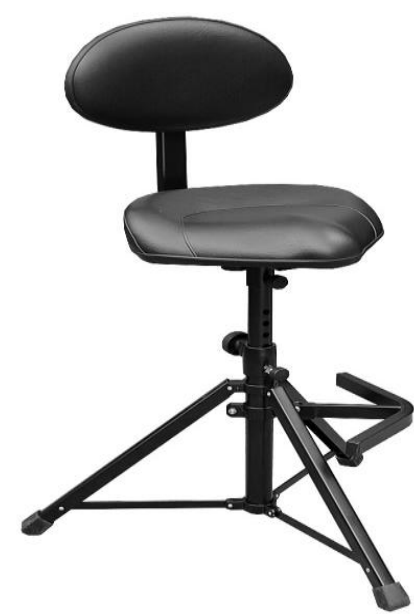

Fig.24.

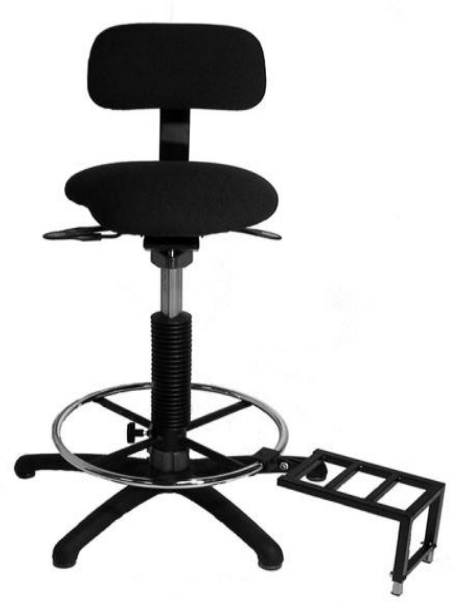

Fig.25.

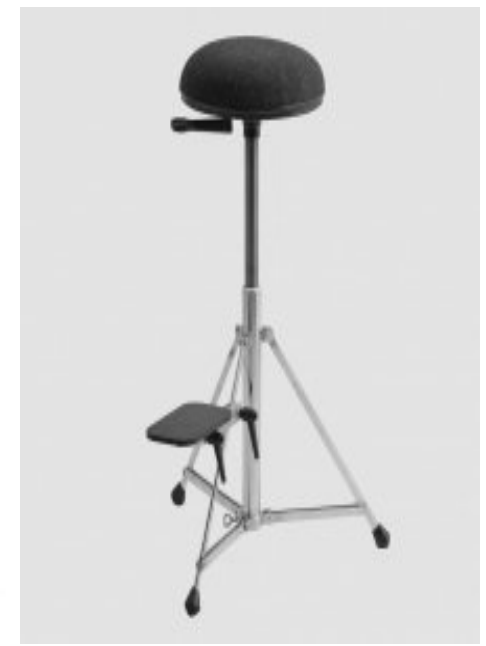

Fig.26. 
Pela escassez de bancos específicos para contrabaixistas há uma saída muito interessante para ajudar a sanar essa falta. Por experiência, usamos um banco que contém selim muito parecido com os usados em bicicleta, em verdade é um banco para tocar bateria (Fig.27).

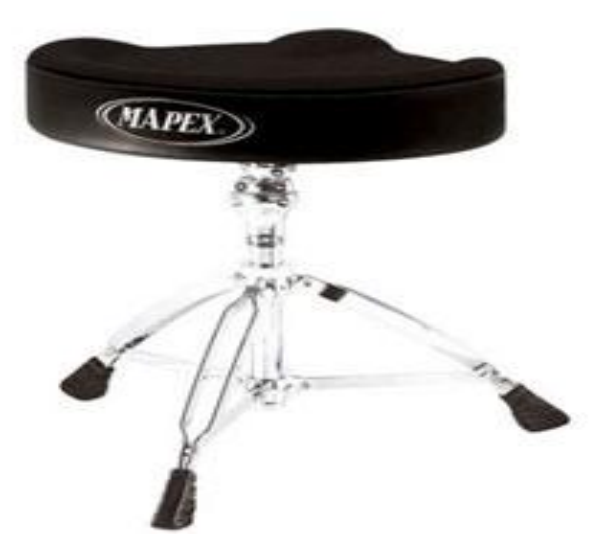

Fig.27.

O selim acomoda muito bem os ísquios e, consequentemente, não provoca desnível corporal; ao contrário, torna-o mais harmonioso e por ter regulagem de altura a um palmo acima do joelho possibilita a postura sentada em ângulo muito próximo dos 45 graus, mais adequado à fisiologia humana.

Catalin Rotaru, contrabaixista Romeno radicado nos Estados Unidos (em nossa opinião e da crítica especializada um dos melhores contrabaixistas solistas da atualidade), em seu repertório de virtuosismos contém: Capricho XXIV de Pagani, Sonata para violoncelo de Brahms, Variações Rococó de violoncelo, concorda conosco sobre a relação altura e banco. Em verdade muito nos honra o mesmo entendimento. Em email ${ }^{50}$ enviado por ele, pede-nos emprestado o referido banco de bateria.

Ainda em referência à postura de forma sentada e a altura do "banco" em relação ao solo e o instrumentista, o Professor e Diretor da American School of Double Bass, Mark Morton, entusiasta e pesquisador sobre as diversas áreas do contrabaixo, ensina: "A maioria dos instrumentistas que tocam o contrabaixo de forma sentada normalmente usam o banco à altura de 76,2 centímetros, apesar de

\footnotetext{
50 "Oi Mauricio,

"I will be back in SP next weekend and I was wondering if I could use your bass stool again; it's a real pain in the ass to find a good one and the one you lent me in December was the perfect height. Thanks a lot and please let me know if it's possible."

Abraco,

Catalin
} 
atualmente haver uma recente tendência de usar o banco com uma altura aproximadamente de 60,96 centímetros."

Por outro lado, Morton também menciona postura interessante correlata. Com o banco alto, a postura é semelhante à primeira narrada por nós; pé direito à frente do instrumento com a face plantar apoiada no chão, o pé esquerdo apoiado no suporte da cadeira em questão, que deverá estar situado a 10 centímetros do chão, baixo repousado sobre o joelho/perna esquerda, o que difere é a altura do instrumento em relação ao instrumentista que deverá ficar entre a axila esquerda e o braço do instrumento na região da nota Mi na corda Sol. Essa distância entre axila e braço fica em torno de 7 a 12 centímetros.

A postura de Miloslav Gadjos, instrumentista e compositor, tem um conceito muito interessante sobre a altura que o músico deve usar. Em suas aulas leciona que a altura do banco deve conter uma relação com os joelhos do contrabaixista, o banco deve estar 10 centímetros acima da altura dos joelhos.

Em relação à altura do instrumento, o professor Gadjos adota duas posturas. Se a música utiliza grande parte da região média aguda do instrumento, aumenta-se a altura do contrabaixo para facilitar o contato com as notas agudas. Em sentido contrário, quando o músico atua à frente de orquestras sinfônicas; abaixa-se a altura do instrumento de forma que possa tornar mais acessível às áreas graves do instrumento. Ressalta-se que a posição postural sentada, adotada pelo Prof. Gadjos tal como os violoncelistas, usa os dois pés no chão, sem apoiá-los na cadeira, como foi mencionado em outra postura. (Fig. 28, 29 e 30)

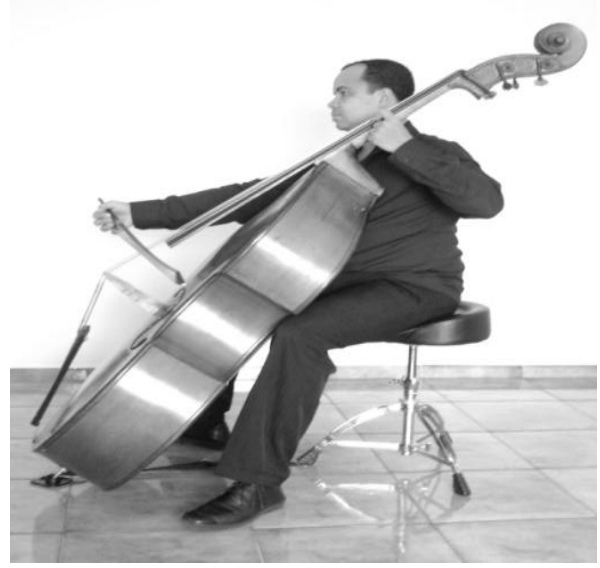

Fig.28.

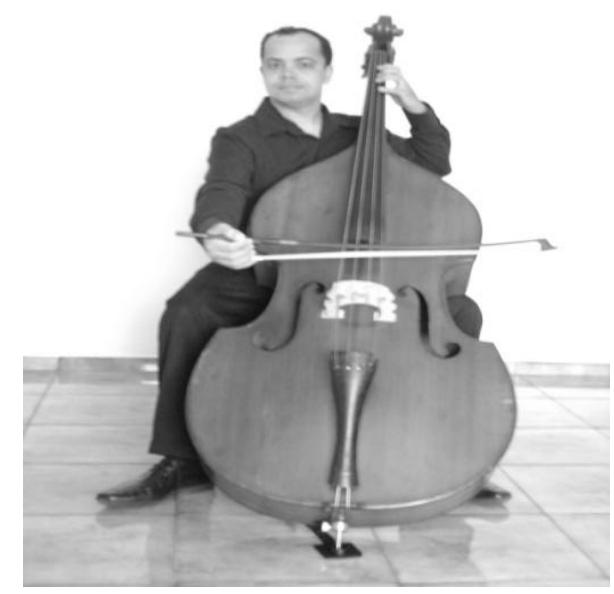

Fig. 29. 


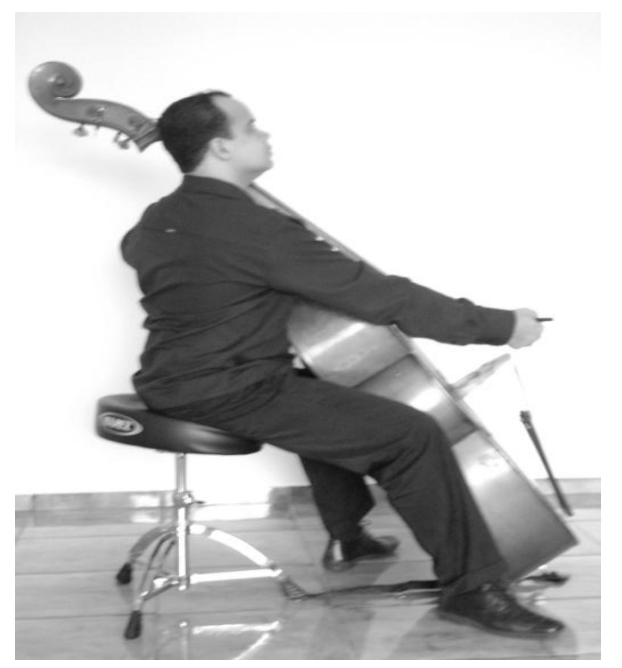

Fig.30.

Wolfagang Güttler, ${ }^{51}$ brilhante músico, vencedor do famoso concurso nacional de Genebra, possui abordagem muito interessante em relação à postura sentada. $O$ professor Güttler usa um apoio para o pé (fig.31, 32 e 33). Em realidade esse apoio é construído e utilizado por instrumentistas que tocam violão.

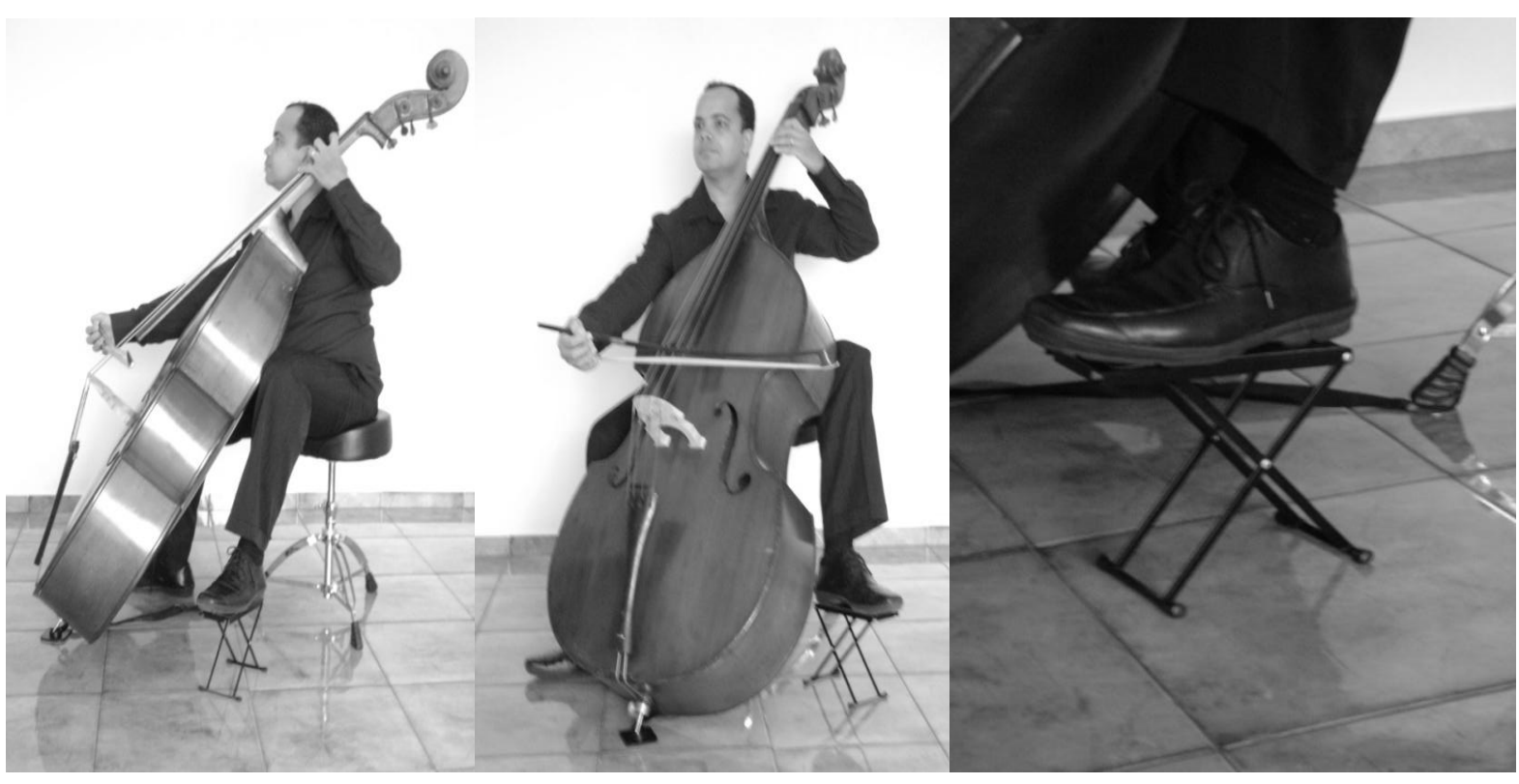

Fig.31.

Fig.32

Fig.33

Quando se toca o contrabaixo na forma sentada, com os dois pés no chão, o ângulo do instrumento será diferente da forma em pé, pois a primeira se assemelha com a postura adotada pelo violoncelo.

\footnotetext{
${ }^{51}$ Nascido em 1945, em Brasov, distrito da Romênia na região da Transilvânia. Foi membro da Orquestra Sinfônica; NDR de Hamburgo e Filarmônica de Berlim.
} 
Ou seja, em pé o instrumento ficará levemente rotacionado para o lado esquerdo. $\mathrm{O}$ apoio de pé serve para inclinar o instrumento a ser suportado pelo joelho, de forma elevada, e evita que o joelho encoste sobre o tampo traseiro e funcione como uma surdina, encostando apenas na contrafaixa lateral. Essa inclinação utiliza o apoio de pé e assemelha-se à inclinação do instrumento nas duas posturas.

Assim, muitas das posturas em tocar o contrabaixo de forma sentada assemelham-se à maneira que os violoncelistas o fazem. Aliás, em nossa opinião não há método que exemplifique melhor essa postura, senão os métodos e a literatura do violoncelo, dentre os quais: New Directions in Cello, cujo principal objetivo é "Como tocar violoncelo de forma fácil e sem dor"52. Certamente um dos melhores livros do mecanismo básico do corpo já escrito para violoncelo, com ilustrações relata aspectos básicos do ângulo da cadeira e respectivos ajustes para assumir a postura sentada, altura da cadeira e alinhamento postural. Indispensável literatura complementar para contrabaixistas.

A respeito de como o violoncelista segura o instrumento, gostaríamos de exemplificar com os ensinamentos de William Pleeth, professor da famosa violoncelista inglesa Jacqueline du Pré.

O professor menciona breves relatos sobre um livro do século XVIII, que descreve a posição correta de segurar o violoncelo. Para fazê-lo de forma cômoda para ser tocado, "repouse o corpo sobre a panturrilha esquerda, a lateral do tampo traseiro sobre a mesma perna, e a lateral do contrabaixo contra a panturrilha da perna direita". Para tanto é necessário que a perna direita esteja situada perpendicularmente ao chão, e a esquerda estendida, ou melhor, o pé esquerdo pode ficar estendido de 10 a 15 centímetros à frente do outro. ${ }^{53}$

Mesmo que essa postura seja a atual denomina-se como "violoncelo barroco", sem espigão para suportar o peso do instrumento. É posição ainda correta para o violoncelo moderno e plenamente aplicável para contrabaixo. Ainda que a posição do violoncelo moderno tenha uma pequena variação: o joelho esquerdo fica ligeiramente um pouco mais atrás do violoncelo, com o propósito de facilitar o toque na corda La e, em consequência, extrair sons mais claros dessa corda.

\footnotetext{
52 SAZER, Victor. New Directions In Cello Playing.

53 PLEETH, William, CELLO, p.146.
} 
Como já mencionamos, devido à escassez de literatura sobre o assunto torna-se muito difícil demonstrar de forma comparada.

Por outro lado, os avanços metodológicos no instrumento vêm crescendo, de forma muito expressiva, em virtude de muitos contrabaixistas explorarem a metodologia violoncelista. É evidente que a função primária do contrabaixo é a sustentação harmônica e rítmica, em condições raras assume a posição melódica, ou seja, na literatura do contrabaixo acústico são raros os autores que se preocupam com essa função melódica.

Por conseguinte, esse é mais um motivo plausível para adotar os métodos de violoncelo, como muitos de nossos colegas fazem. Por isso os contrabaixistas que obtêm nível técnico mais apurado, sem sombra de dúvidas são os que contêm em seus repertórios sonatas e suítes de violoncelo como: Edgar Meyer, contrabaixista e compositor; Gary Karr, solista e professor; Edwin Barker, principal contrabaixo da Orquestra de Bonston; Rinat Ibraguimov, principal contrabaixo da Orquestra Sinfônica de Londres entre outros.

O uso de cordas de metal, a evolução do instrumento, o surgimento de solistas que emprestam a maneira de executar outro instrumento e trazem suas especificidades para o contrabaixo nos dias atuais, são fatos inegáveis.

\section{- Posições Comparadas}

Deste ponto em diante, compararemos com ilustrações e respectivos comentários as distinções das posturas e das formas de segurar o instrumento; a metodologia, como também vantagens e desvantagens, quando se adota uma ou outra posição.

As costas, em particular a coluna ou espinha dorsal, na postura sentada, devem ser mantidas de forma ereta o tempo inteiro, o que é quase impossível, uma vez que a própria estrutura não é reta. Um bom exemplo para aliviar as tensões nessa área é derivado da técnica de Alexander ${ }^{54}$ :

\footnotetext{
54 FREDERICK, Matthias Alexander (1869-1955) foi um homem à frente do seu tempo. No final do século XIX desenvolveu trabalho revolucionário sobre o desenvolvimento do ser humano, trabalho este que, ao longo dos anos, atraiu diversas personalidades da Ciência, da Educação e das Artes. Pode-se dizer que Alexander foi
} 


\begin{abstract}
"Imaginar uma corda amarrada e puxando de forma vertical o pescoço para cima, deste modo alongando região lombar ligeiramente curvada para dentro. Em relação às notas agudas não esquecer que para alcançá-las deverá o músico flexionar o quadril".
\end{abstract}

Uma das vantagens trazidas por essa postura é a liberdade da mão esquerda em "trafegar" por todo o espelho do instrumento, ou seja, as mudanças de posições entre graves e agudos podem ser feitas como mais facilidade. Na posição em pé, necessariamente a mão esquerda também é responsável por "segurar o instrumento" até mesmo em posturas que suavizam essa função, como a adotada pelo Prof. Streicher. Ainda assim, o peso do instrumento recai sobre a mão direita, porém o peso recai sobre o ombro esquerdo e o quadril, nas posições agudas. A postura em pé oferece certa liberdade, pois o músico não está de forma fixa na cadeira; é possível "balançar" com a música e, até mesmo, andar pequenas distâncias, enquanto toca o contrabaixo. Essa gama de movimentos é benéfica como meio de expressão, intensifica e projeta o conteúdo emocional da música. Contudo a posição sentada não é completamente restritiva e há muito mais liberdade no que se refere aos movimentos físicos do instrumento com o espírito da música.

A postura sentada é usualmente utilizada pela maioria dos músicos das orquestras brasileiras, nas já mencionadas cadeiras altas tipo "giroflex".

Em nosso entendimento, com tempo esse uso trará consequências danosas a nossa estrutura musculoesquelética e na técnica de execução do instrumento, porque a cadeira não é apropriada para esse fim.

O principal problema é de sustentação corpórea, pois o encosto das regiões lombar e dorsal fica muito longe das costas, ou seja, o encosto fica muito longe das costas devido ao próprio contrabaixo e porque o assento é muito grande, impedindo assim que o músico use o encosto. Desse modo, depois de alguns anos, serão realidade os problemas relacionados a: costas, hérnia de disco, bico de papagaio e afins.

Por outro lado, a postura apresentada por Miloslav Gadjos é muito interessante e produz bons efeitos em vários aspectos, por ser a mais próxima de

pioneiro no Ocidente a desenvolver um trabalho em que o homem é visto como unidade psicofísica. http://tecnicadealexander.com/tecnica.htm 
priorizar ou minimizar os efeitos dos "anos" de instrumento e de longas horas de prática e ensaios. Em vez de usar a cadeira desenhada para suportar as pernas e deixar o instrumentista acima da altura dos cellos, (fig.34) como dito por nós, ele regula o contrabaixo a uma altura mais baixa para que os joelhos fiquem ao ângulo das pernas em aproximadamente 45 graus. A postura é muito relaxante e minimiza a fadiga da prática do contrabaixo, uma vez que o "sistema" não fica afetado e há um equilíbrio geral o que traz melhoras técnicas. O ponto negativo talvez seja a ação do arco, pois mudará o ângulo de encontro do arco com as cordas e exigirá mais esforço do ombro, outro grupo de músculos do braço analisados adiante por nós quando comentarmos sobre o arco.

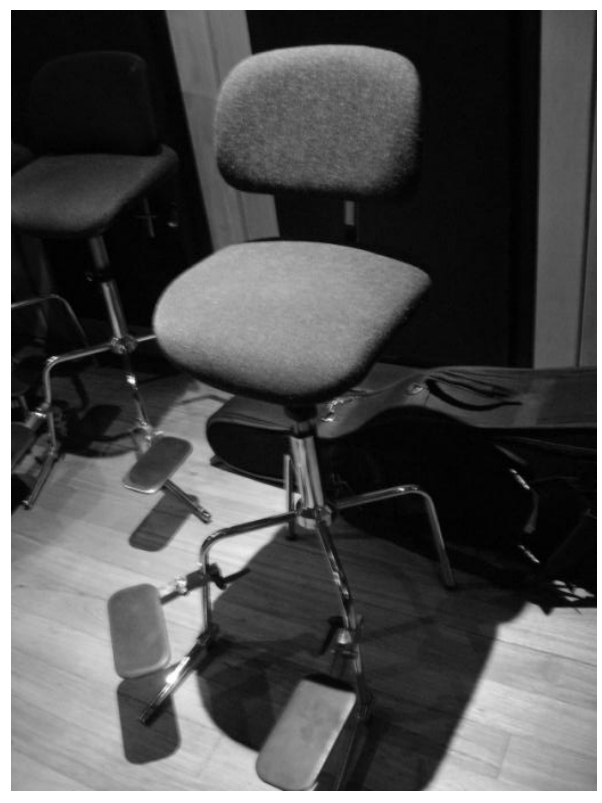

Fig.34.

Sobre a postura sugerida pelo Prof. Willian Pleeth, apenas reitere-se que, por analogia, é perfeitamente funcional ao contrabaixo. É claro que, por aspectos funcionais; tamanho e forma não há possibilidade de assumir a mesma posição postural do violoncelo, mas é possível aproveitar os benefícios da postura.

A proposta de Wolfgang Güttler, com o apoio de pé, mostra-se muito efetiva, principalmente pelo fato de viabilizar boa funcionabilidade no que se refere à execução. A pronação será lateral, exatamente como quando se executa o instrumento de forma em pé. 
Ovidio Badila, Catalin Rotaru, Hans Hoelofsen, Miloslav Gadjos, Mark Morton, são apenas alguns dos muitos que emulam a abordagem violoncelística.

Com isso, de forma comparativa e ilustrativa, exteriorizamos nosso entendimento sobre os mecanismos primários e posturas utilizadas pelos contrabaixistas de forma ampla, tanto na posição postural em pé como na sentada. 


\section{ANÁLISE DO MOVIMENTO}

No contexto da prática instrumental, a compreensão dos aspectos envolvidos na produção do movimento mostra-se essencial na organização de estratégias de estudo mais eficientes, o que inclui conhecimento dos aspectos anatômicos e fisiológicos do corpo humano. "Estas ciências [como a Anatomia e a Fisiologia] deveriam ser os pilares de sustentação do processo de ensino-aprendizagem dos instrumentos musicais". (KAPLAN, 1987, p.13). Os movimentos participantes na ação instrumental encontram-se interligados em complexas estruturas anatômicas, e somente através do completo domínio dessas estruturas pode-se atingir alto nível de eficiência. "A execução instrumental requer habilidades altamente refinadas e um alto grau de conscientização corporal, para que se possa atingir uma realização ótima". (CIARLINI e RAFAEL, 1994, p.32).

Em referência à ação contrabaixística, é importante conhecer não apenas a proposta do movimento, mas também sobre os fatores de desempenho inerentes à execução habilidosa desse movimento, tais como, força, fadiga, rapidez, flexibilidade.

Para entender os princípios e as formas de movimentos no contrabaixo é necessário examinar a fundo não somente a composição como também o processo de aprendizado. É claro que os desdobramentos em análise, tratam mais do que os componentes biomecânicos propriamente ditos, pois estes esbarrariam na parte prática em tocar instrumento como a memória muscular ou a também denominada memória do movimento, descrita como a habilidade de repeti-lo. ${ }^{55}$ Assim, ultrapassada certa fase do aprendizado, os movimentos acontecem simplesmente. Isto é, a memória muscular pode ser muito útil para certos movimentos, mas com muita cautela. É comum que alguns músicos a utilizem, mas em realidade apenas sabem "onde apertam os dedos", ou seja, há despreparo intelectual.

Por outro lado, racionalizar o movimento não significa usar algema, de modo que o músico tenha de intelectualizar cada movimento para realizá-lo. Desse modo, o nosso entendimento é que devemos nos ater "ao melhor dos dois mundos"; ter

\footnotetext{
${ }^{55}$ MANTEL, Gerhard. Cello Technique, Principles and Forms of Moviment.
} 
consciência sobre o movimento, entender e usar as particularidades, para aperfeiçoar a produção artística.

A análise do movimento torna-se necessária por conta da frequência e da distância das mudanças de posições empregadas para tocar contrabaixo. Assim os contrabaixistas, mais do que outros instrumentistas, são obrigados a desenvolver eficiente e acurado sistema de mudança de posições, que não se limitam a alternar as mãos de um lugar ao outro. ${ }^{56}$

O tamanho físico do instrumento e a resposta sonora das notas não equivalem ao que se alcança um piano, dadas as peculiaridades. Assim, soluções técnicas deverão ser aprimoradas para esse fim.

Parta-se do princípio de que o intervalo de um tom na 1/2 posição da corda Mi possui aproximadamente 14 centímetros, isto é, se o instrumento possui em média um tiro de corda de 106 centímetros, entre o cavalete e a pestana, e dependendo do sistema de mudança de posição adotado pelo instrumentista na execução, efetivamente deve-se mudar de posição a cada duas notas. O contrabaixista Ludwig Streicher, em seu livro My way to play Double bass, categoricamente afirma que é de excelente qualidade o músico que consegue ultrapassar essas limitações inerentes ao instrumento, quando faz as mudanças de posições de forma imperceptível, como se não existissem. Desse modo, é imperativo ao músico o estudo do movimento e suas fases.

\footnotetext{
${ }^{56}$ MORTON, Mark, Double Bass: Concept and Ideas, pg 65.
} 


\section{AS TRÊS FASES DO MOVIMENTO}

Os praticantes de esportes usam uma sequência básica de movimentos. Não apenas eles, mas qualquer pessoa em seu dia a dia, seja em tarefas domésticas ou profissionais, utiliza as fases do movimento. Essas fases são classificadas como; 1) preparação, 2) o movimento em si, e 3) restabelecimento ou retorno a posição inicial.

As fases descritas são plenamente aplicadas à execução do contrabaixo acústico - tanto na mudança de posições na mão esquerda, quanto ao uso do arco na direita. Músicos possuem pontos similares aos atletas/ginastas. De ambos, em suas atividades, são exigidos: alta proficiência física, equilíbrio e graça ${ }^{57}$.

Primeiramente, movimentos abruptos devem ser evitados em ambas as mãos, pois a mudança brusca não afetará só a nota ou a arcada original; o movimento deve "sobreviver" de forma harmoniosa à nota de chegada, ou seja, o repouso da nota em que repousa o movimento.

$\mathrm{Na}$ fase da preparação, o movimento deve ser mentalmente percorrido. Essa é uma ótima sugestão para aprimorar o resultado, pois - ao visualizar mentalmente o movimento - já tem em mente o resultado pretendido. Esse método é comumente utilizado por desportistas como o ex jogador de basquete da NBA, Michael Jordan ${ }^{58}$.

O movimento em si deve ser sempre homogêneo e relaxado. Em se tratando do movimento preparatório, tomemos o exemplo de uma mudança de posição; forma ascendente da nota $A$ da corda $G$ para a nota Mi da mesma corda com o dedo 1 da mão esquerda.(fig.35)

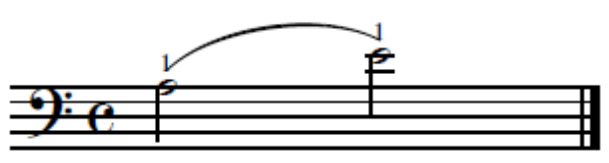

fig. 1

Fig.35.

\footnotetext{
${ }^{57}$ SAZER, Victor, New Directions in Cello Playing.

${ }^{58}$ FREYMUTH, Malva Susane. Mental Pratice an Imagery for Musicians: a practical guide for optimizing pratice time, enhancing performance, and preventing injury. Boulder, CO: Integrated Musician's Press, 1999.
} 
Apesar de o corpo se preparar para movimento ascendente na mudança da nota em questão, a preparação do movimento deverá ser outra. Ocorre que a primeira fase é a preparação do impulso; assim, o movimento terá direção inversamente proporcional à direção pretendida.

Isso quer dizer que a compreensão do movimento é simples, ao comparar o movimento de um tenista, quando acerta a bola com a raquete. Basta observar que, para atingir a bola, o movimento estrutural, principalmente de ombros e cotovelos, é inverso à direção que se pretende atingir ou para a qual a bola será arremessada.

O movimento em si é autoexplicativo. Após a preparação, ele ocorre de forma natural, sem esquecer que toda força motriz parte do centro corpóreo de gravidade, a pélvis, principalmente quando o instrumentista estiver sentado.

O terceiro estágio é o restabelecimento natural, em realidade poderia até ser denominado primeiro estágio ou até ser qualificado como inércia, por ser ausência de movimento. Então, o movimento corporal é baseado no seguinte esquema:

1. Determinamos a meta ou objetivo (movimento). Essa concepção pode ser visual ou acústica. Visual porque podemos olhar para o instrumento e desejar o movimento de partida e de chegada, ou melhor, onde recairá a nota em questão, tratando do movimento da mão esquerda por exemplo. A acústica, por sua vez, pode ser encarada como a habilidade de o executante reconhecer que o ponto de chegada condiz com a expectativa sonora desejada. Entendemos que somado à acústica, acontece outro fenômeno: a cinestesia, que é o sentido pelo qual se percebem os movimentos musculares, o peso e a posição dos membros.

2. O cérebro envia mensagens ao sistema motor. Não adentraremos na seara dos estudos neurológicos, por não ser escopo deste trabalho, porém ocorrerem impulsos elétricos que, por sua ordem, serão responsáveis pelo movimento ${ }^{59} \mathrm{~A}$ frequência dos impulsos elétricos e o número de fibras envolvidas determinarão a amplitude e a força do movimento, respectivamente.

3. Assim, no caso de o movimento pretendido falhar, isto é, se ocorrer uma nota desafinada, escrocada ou diferente da pretendida, o cérebro é avisado pela proprioceptividade, pela qual esses impulsos elétricos informam ao cérebro se houve ou não sucesso do movimento. É claro que $o$ instrumentista deve possuir um nível mediano de conhecimento que o permita identificar o que é correto ou não.

\footnotetext{
${ }^{59}$ A ordem do cérebro saudável - mexa-se! - alcança, primeiro, a parte externa da medula. Dali, em alturas diversas da coluna vertebral, as terminações nervosas penetram até o centro, onde ficam os neurônios motores. Esses, por sua vez, saem novamente, desembocando em 31 pares de nervos espalhados entre as vértebras. Eles levam esse tipo de comando voluntário para cada músculo do corpo humano. Revista SUPERINTERESSANTE. Ed. 114, março.1997.
} 


\section{MOVIMENTOS "ATIVOS E PASSIVOS"}

Seja para mudanças de posições ou para executar o instrumento com o arco, o movimento "ativo" deve necessariamente começar no braço. Para os leigos, e até mesmo na linguagem vulgar, o braço é conhecido como sinônimo da extremidade superior ou membro superior do homem.

Contudo, em anatomia, o termo braço é a porção proximal do membro superior, formada pelo úmero, que articula no ombro, com a escápula, cotovelo, com a ulna e o rádio, que formam o antebraço.(fig.36)

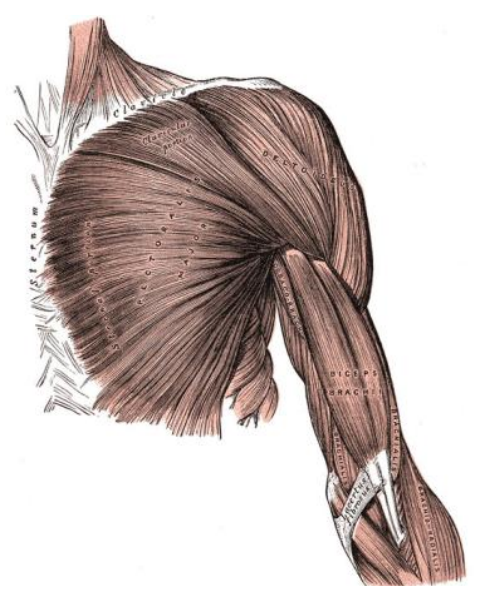

Fig.36. Antebraço http://pt.wikipedia.org/wiki/Bra\%C3\%A7o

Ou seja, se pensarmos no movimento do arco, os movimentos ativos iniciamse no braço e desdobram-se, passam pelo antebraço onde serão "passivos"; do mesmo modo pelo pulso, dedos e até atingir o objetivo que é a produção de som do contato do arco com a corda.

Os termos, ativo e passivo, devem ser considerados como relativos, pois nesse exemplo a passividade do antebraço é quase impossível; assim, o arco poderia cair da mão do executante ou mesmo o contrabaixo, se considerada a passividade como ausência de movimento. $O$ correto é levar em consideração que o braço é maior que o cotovelo, desse modo se torna mais simples imaginar que 0 movimento é conduzido por este último.

Como o objetivo do presente trabalho é fornecer ao músico elementos comparativos sobre a biomecânica, faremos um breve relato sobre os movimentos. 


\section{MOVIMENTOS ARTICULARES AXIAIS}

Deste ponto em diante trataremos sobre os movimentos de acordo com sua classificação, como forma supletiva ao capítulo sobre Análise Biomecânica postural.

As articulações classificam-se quanto ao número de eixos. Observe-se que os movimentos são permitidos por uma articulação e seguem critérios específicos, pois acontecem em torno de eixos. Os axiais utilizam em seu conceito os respectivos planos e eixos em que ocorrem. Esses conceitos utilizam a posição anatômica, isto é, partem ou retornam a esta última.

A seguir, veremos o conceito dos movimentos articulares axiais ${ }^{60}$, de tal sorte, trançando um paralelo aos movimentos usados para a execução do contrabaixo acústico.

\section{- Flexão}

Movimento realizado a partir da posição anatômica sobre o plano sagital em torno do eixo transversal, caracterizado pelo aspecto de aproximação, na qual diminui o ângulo interno relativo, entre dois segmentos adjacentes. Em algumas articulações, para qualquer lado que o movimento seja realizado, esse conceito encaixa-se (por exemplo, a articulação do quadril ou do ombro).

Essa flexão ocorre, quando movimentamos um dos braços. Terá a forma horizontal, quando executarmos uma nota, por exemplo, do talão à ponta; e vertical, quando levantarmos o arco da corda, a que denominamos supinação.

Outro movimento articular, presente na execução do instrumento, é a flexão, palmar e dorsal. Nas diversas escolas, leia-se metodologia própria de execução, algumas delas usam a flexão do pulso para execução do arco. Quando a nota é

\footnotetext{
${ }^{59}$. O movimento nas articulações depende, essencialmente, da forma das superfícies que entram em contato e dos meios de união que podem limitá-lo. Na dependência desses fatores, as articulações podem realizar movimentos em torno de um, dois ou três eixos. Esse é o critério adotado para classificá-las funcionalmente. Quando uma articulação realiza movimentos apenas em torno de um eixo, diz-se que é monoaxial ou que possui um só grau de liberdade; será biaxial a que os realiza em torno de dois eixos (dois graus de liberdade); e triaxial, se eles forem realizados em torno de três eixos (três graus de liberdade). Assim, as articulações que só permitem flexão e extensão, como a do cotovelo, são monoaxiais; aquelas que realizam extensão, flexão, adução e abdução, como a radiocárpica (articulação do punho), são biaxiais; finalmente, as que além de flexão, extensão, abdução e adução, permitem também a rotação, são ditas triaxiais, cujos exemplos típicos são as articulações do ombro e do quadril.
} 
tocada com o talão, ocorrerá a flexão dorsal (fig.37 e 38) e, por sua vez, em sentido oposto ocorrerá a flexão palmar (fig.39 e 40), para os adeptos da escola alemã, ou seja, aos que utilizam o arco alemão, também chamado de Dragonetti ${ }^{61}$. Por outro lado, outras escolas, como a Americana, não usam a flexão palmar ou dorsal, ou a utilizam de forma mínima.

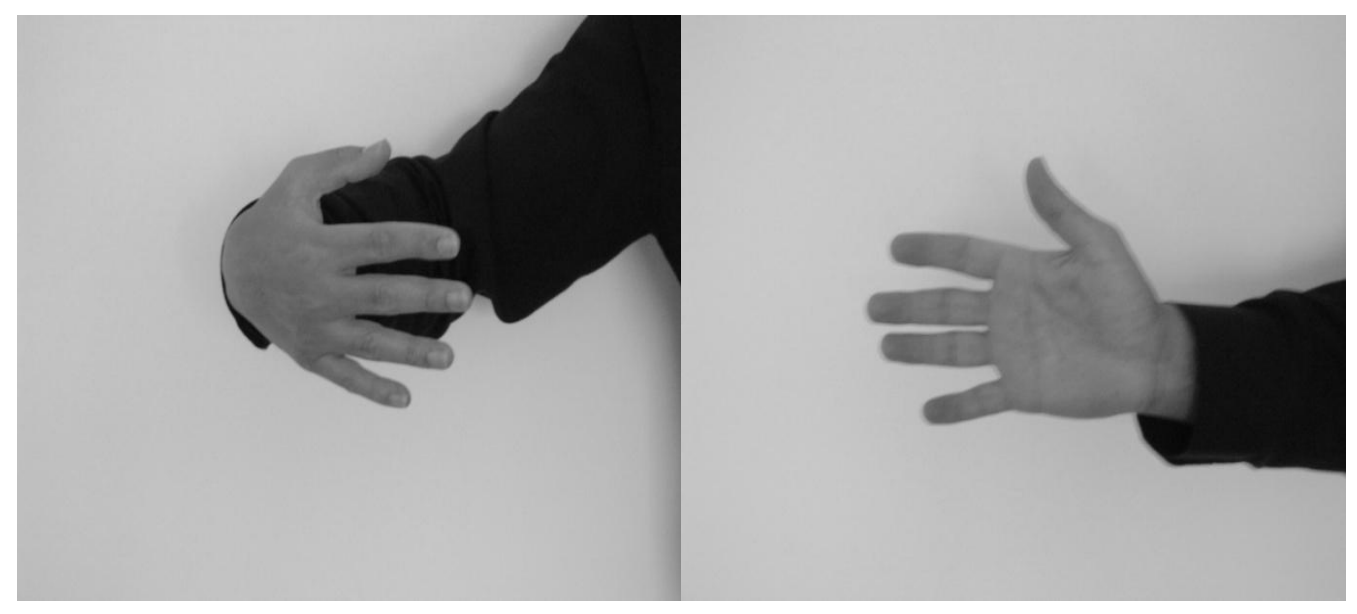

Fig. 37.

Fig.38.

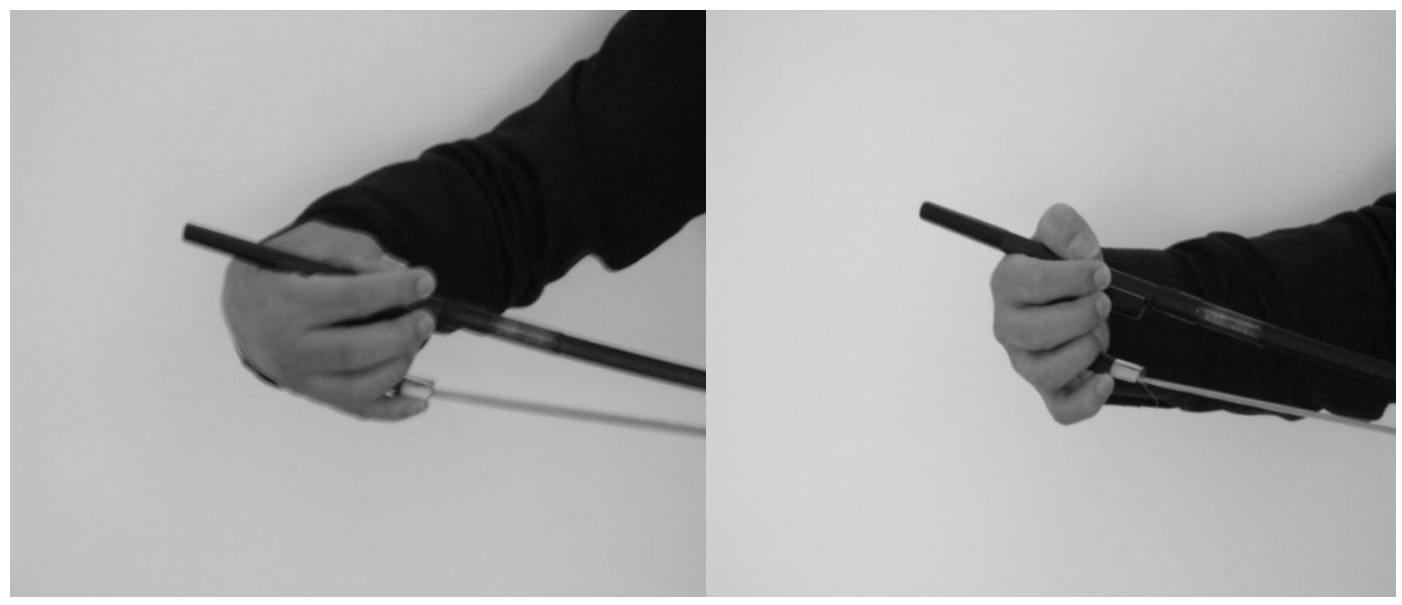

Fig. 39.

Fig.40.

\footnotetext{
${ }^{61}$ Famoso contrabaixista e compositor italiano nascido em 1763, em Veneza, e falecido em 1846. Após fixar-se em Londres em 1794, tornou-se amigo do não menos conhecido violoncelista Lindley. Travou também amizade com Haydn e Beethoven. Produziu diversas composições originais, bem como arranjos de muitas outras obras para contrabaixo. Acabou por legar todo o seu espólio musical ao Museu Britânico. É considerado o mais importante virtuoso do contrabaixo da sua época. (Domenico Dragonetti. Porto Editora, 2003-2009).
} 


\section{- Extensão}

Ocorre, quando o movimento é realizado pelo retorno à posição anatômica e, por vezes, por ultrapassá-la e manter-se o movimento. Estão presentes, por exemplo, nas articulações de quadril, ombro e punho, sobre o plano sagital e em torno do eixo transversal, caracterizado pelo aspecto de afastamento, no qual é aumentado o ângulo interno relativo entre dois segmentos adjacentes.

Em realidade, a solução da problemática é visualizar que partindo da posição inicial anatômica, ou seja, o lado que tiver menor amplitude de movimento será a extensão.

A extensão é presente em métodos de contrabaixo, quando - numa mesma posição - é executado mais do que um tom e meio, mas isso será objeto de estudo nos sistemas de posições. Desse modo, a extensão é observada na forma de executar o instrumento, somente quando são tocadas notas com a mão esquerda, o que descartado qualquer movimento de extensão de quadril, punho ou braço para tocar o contrabaixo.

Entendemos, porém, que talvez a postura em que se execute o arco alemão; (punho semiflexionado) possa ser considerada extensão, isto é, com os dedos contraídos em direção à palma.

Para visualizar a extensão dos punhos e entender essa posição, basta imaginar que eles são utilizados tipicamente em combates desarmados, tais como o boxe.

- Abdução

Movimento realizado sobre o plano frontal e em torno do eixo sagital, caracterizado pelo espaço do afastamento, no qual o segmento corporal, partido da posição anatômica distancia-se da linha mediana do corpo e será assim considerado, enquanto o movimento ocorrer. $\mathrm{Na}$ articulação do punho, também pode ser chamada de flexão radial ou desviorradial.

A abdução pode ser usada em ambas as mãos e, inversamente proporcional, já explica a adução. Quando usamos o arco francês, que obviamente dispensa 
apresentações, é exatamente com as devidas proporções de tamanho similar ao arco de violino.

No arco alemão, como já explicitado, é comum a mudança de direção do arco utilizando a flexão palmar ou dorsal. No francês, é utilizada a Abdução (fig.41 e 42), ou seja, o arco tendo início para cima ou em direção ao talão. Por sua vez a Adução (fig.43 e 44) terá sentido inverso.

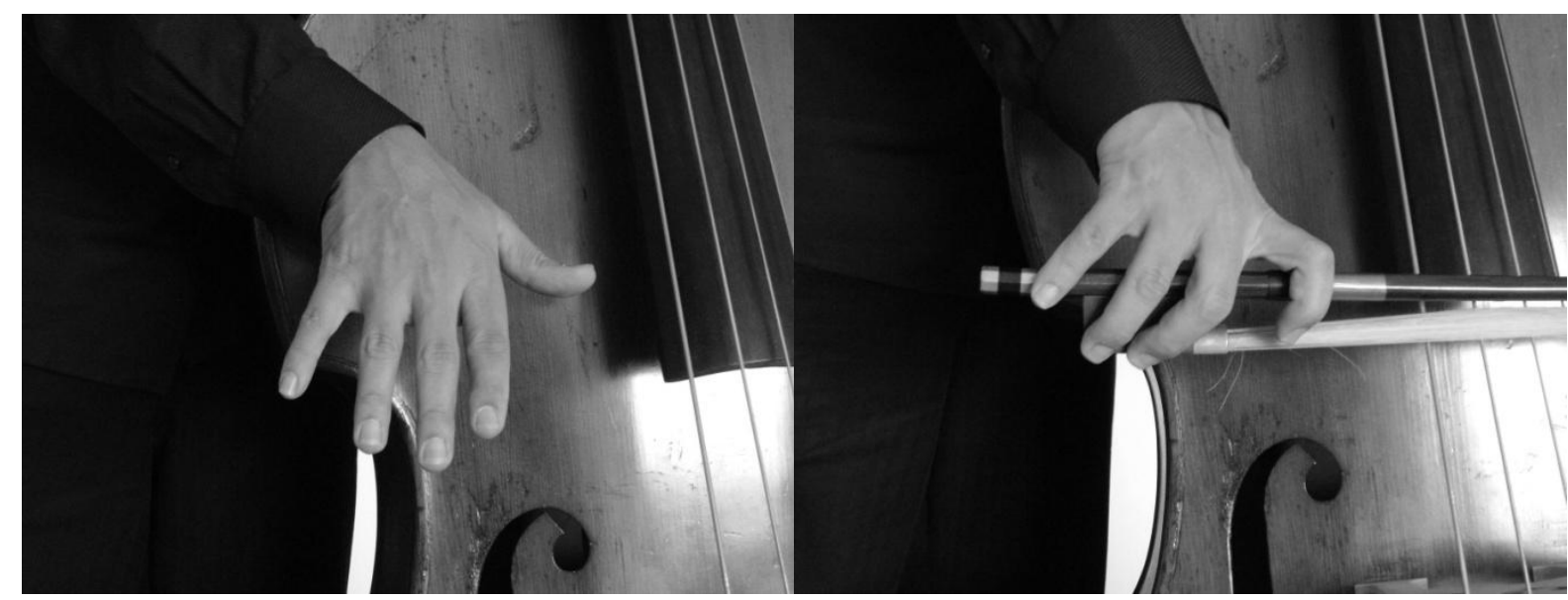

Fig.41.

Fig.42.

- Adução

Movimento realizado sobre o plano frontal e em torno do eixo sagital, no qual o segmento corporal aproxima-se da linha mediana do corpo e será assim considerado, enquanto o movimento ocorrer. Na articulação do punho, tanto a abdução como a adução, podem ser chamadas de flexão ulnar ou desvio ulnar.

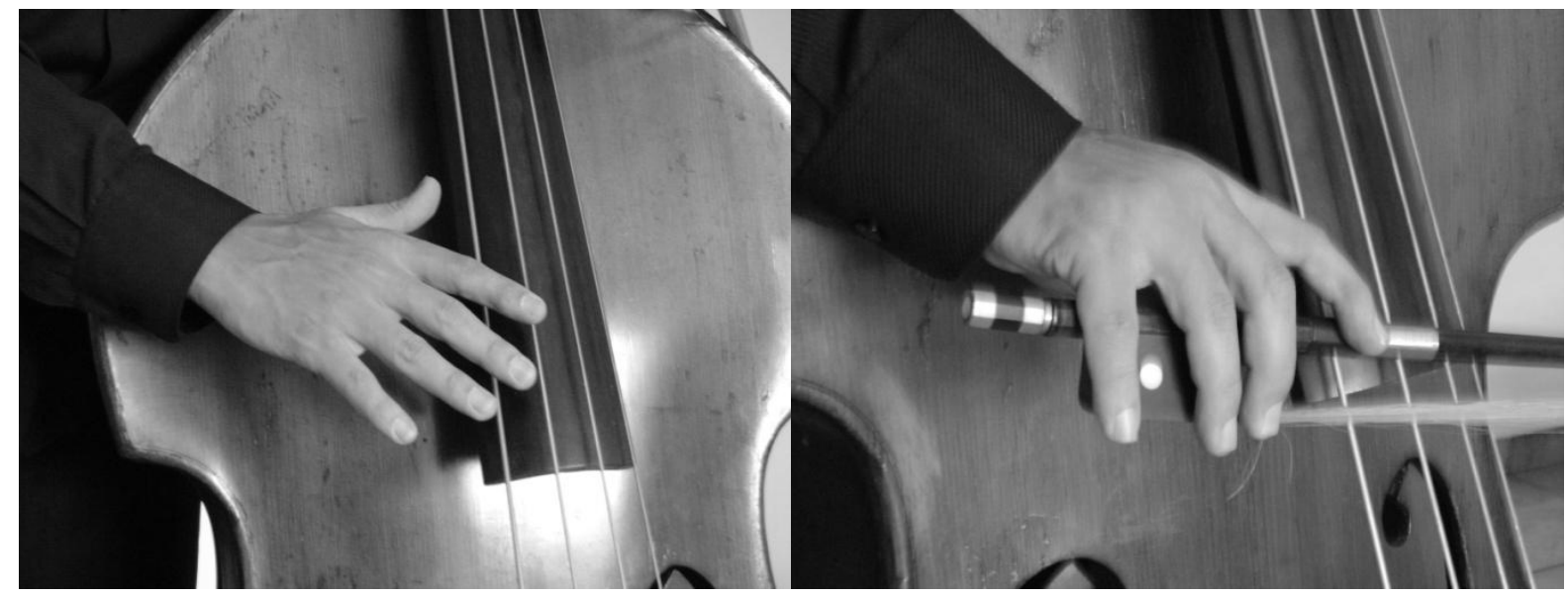

Fig.43.

Fig.44. 
Esses movimentos podem ser utilizados também pela mão esquerda, quando se tratar de mudança de posição em relação à nota; exatamente como dito no início deste capítulo.

O exemplo e a forma descrevem as fases dos movimentos para se alcançar a nota Mi na corda Sol, a partir da nota La de mesma corda, incluiremos a mão esquerda para executar o movimento de abdução e adução, (em sentido contrário em alcançar a nota final desejada).

- Rotação Interna ou Externa

Rotação interna é o movimento realizado sobre o plano frontal e em torno do eixo longitudinal, no qual o segmento corporal girará em torno do seu maior eixo, voltando a face anterior para a linha média do corpo.

A Rotação Externa, por sua vez, difere-se desta última, porque o segmento corporal girará em torno do seu maior eixo, voltando a face anterior para o lado oposto da linha média do corpo.

As duas rotações são amplamente utilizadas para tocar contrabaixo, pode-se constatar, por exemplo, na mão esquerda, quando se executa o vibrato: a rotação é auto-explicativa.

Na posição anatômica do contrabaixo, apertando a nota La na corda Sol com o segundo dedo da mão esquerda, o antebraço movimenta-se nos dois sentidos horário e anti-horário.

Já na mão direita, podemos visualizar a rotação ao exemplificar a pronação. Tanto faz se o instrumentista utiliza o arco alemão ou francês, ele dever pressionar a corda para produzir som, assim a rotação anti-horária se faz presente.

- Pronação

Movimento que acontece na articulação radio ulnar proximal que, mesmo sendo muito semelhante ao movimento de rotação lateral, possui esse nome por ter mais uma característica: o retorno do rádio à posição anatômica.

Voltando ao exemplo da nota La na corda Sol, exemplo típico de pronação que só ocorre, quando o executante encontra-se na posição sentada. Dessa forma, 
o instrumento recai sobre o ombro direito, e a pronação ocorrerá conforme ilustração. Por outro lado, salientamos que, quando o músico se encontra em pé, a pronação pode ocorrer em menor escala, pois a corda será apertada, ou seja, a pressão em relação à corda se dará pela ação dos dedos opositores.

A pronação também ocorre, quando o executante utiliza o arco para tocar o instrumento, com isso não importa qual o tipo; em realidade os dois possuem os movimentos, tanto pronação quanto supinação e serão descritos em momento oportuno. 


\section{DORES RELACIONADAS À PRÁTICA DO INSTRUMENTO}

Nosso objetivo na vida profissional é a produção musical. Lutamos todos os dias para $\mathrm{o}$ aumento de habilidades em nossos instrumentos exatamente para "recriar" músicas de forma fácil e expressiva. No entanto, é vital manter em mente que violinos, violoncelos, flautas e trombones são apenas meio caminho do percurso. Eles nada podem fazer, enquanto não interagirem com o físico e o emocional que compõem a natureza humana. ${ }^{62}$

Aliás, a prática demasiada ou intensa, por dias, meses e anos sem precauções certamente prejudicará o corpo. É comum, no meio musical, alguns músicos que contrariam as regras de higidez postural e até mesmo praticam por dias a fio e gabam-se de não sentir dores relacionadas à prática do instrumento. Porém, estes são exceções à regra. $O$ importante é que, quando há referência a dores pelo uso do instrumento, os mais afetados são os que militam profissionalmente.

Todavia entendemos que a prática demasiada talvez não seja notada pelo instrumentista a curto prazo; desse modo, os problemas chamados pela legislação trabalhista como "acidente de trabalho" costumam acontecer na meia idade. É claro que o tema em questão deve ser encarado de forma profilática.

No Brasil existe legislação específica responsável,quando o músico está acometido de alguma doença que tenha nexo de causalidade com a atividade profissional. De forma ilustrativa conceituamos o acidente de trabalho:

De acordo com o Artigo 19 da Lei o 8.213, publicada em 24 de julho de 1991, a definição de acidente de trabalho é:

o que ocorre pelo exercício do trabalho a serviço da empresa, ou pelo exercício do trabalho do segurado especial, provocando lesão corporal ou perturbação funcional, de caráter temporário ou permanente". Essa lesão pode provocar a morte, perda ou redução da capacidade para o trabalho. A lesão pode ser caracterizada apenas pela redução da função de determinado órgão ou segmento do organismo, como os membros.

\footnotetext{
${ }^{62}$ HORVATH, Janet. Playing less Hurt, 2009 revised edition.
} 
Além disso, é considerada como doença do trabalho aquela produzida ou desencadeada pelo exercício de determinado trabalho. Pode-se ilustrar com o exemplo de músico que possui tendinopatia gerada por má postura ou LER ${ }^{63}$. Ou seja, depende das condições em que a função é exercida. A sobrecarga de funções possui relação intrínseca com a doença profissional, senão, similar e fatalmente poderá gerar os malefícios da LER.

Voltemos às exceções: até mesmo um expert no assunto não poder afirmar com precisão as habilidades musicais que as mãos poderão desenvolver e, ao contrário, quais as possíveis patologias.

Como podemos explicar o fato de duas mãos, que pertencem a dois diferentes indivíduos, aparentemente idênticas em tamanho e dedos, serem diferentes em suas ações?

A experiência da vida prática mostra que para alguns há necessidade de atividade diária para manter a flexibilidade; enquanto para outros, pode-se não usálas por semanas e, depois de algumas "ginásticas para os dedos", quer dizer, alguns exercícios e aquecimentos, com pouco investimento de tempo, retornam à agilidade sem muito trabalho. Como visto é aparentemente inexplicável o fato de conhecidos virtuosos serem obrigados a ter uma prática contínua de ordem para manter a forma, enquanto outros podem permitir-se longos períodos sem tocar o instrumento. ${ }^{64}$

Outro ótimo exemplo, que foge totalmente à regra é do contrabaixista russo Rodion Azarkhin ${ }^{65}$ que teve sua última performance conhecida na Convenção de Contrabaixo de Mittenwald, em 1991. Conforme excerto publicado e lido em 2001, na Sociedade Internacional dos Contrabaixistas sob o título A Vida e o Trabalho de

\footnotetext{
${ }^{63}$ Representa uma síndrome de dor nos membros superiores, com queixa de grande incapacidade funcional, causada primariamente pelo próprio uso das extremidades superiores em tarefas que envolvem movimentos repetitivos ou posturas forçadas. Também é conhecido por L.T.C. (Lesão por Trauma Cumulativo) e por D.O.R.T. (Distúrbio Osteomuscular Relacionado ao Trabalho), mas na realidade entre todos estes nomes talvez o mais correto tecnicamente seria o de Síndrome da Dor Regional. Contudo, como o nome L.E.R. se tornou comum e até popular, essa é a denominação adotada no Brasil, e representa exatamente o que se trata a doença, pois relaciona sempre tais manifestações com certas atividades no trabalho. O diagnóstico diferencial deve incluir as tendinites e tendossinovites secundárias a outras patologias, como reumatismo, esclerose sistêmica, gota, infecções gonocócicas, traumática, osteoartrite, diabetes, mixedema, etc., uma vez que estas também representam frequentes lesões causadas por esforço repetitivo. WIKIPÉDIA, A Enciclopédia Livre.

${ }^{64}$ AUER Leopold, Violin Playing, As I Teach It.

${ }^{65}$ Contrabaixista russo, renomado por suas transcrições para o instrumento; sonatas de violoncello, concertos de Dvorak e Schuman para violoncelo, Chacona da Partita no.2, BWV 1004 como também alguns caprichos de Paganini para violino, Rodion Azarkhin é considerado um dos grandes contrabaixistas do século XX.
} 
Rodion Azarkhin, diz que ele não tocava há mais de dois anos para tratar da mãe que se encontrava hospitalizada. Convidado para a convenção na Alemanha, um contrabaixista em São Petersburgo emprestou-lhe um instrumento por duas semanas antes do evento. "Por duas semanas eu pratiquei/estudei, eu consegui ter a minha técnica de forma rápida. Após as duas semanas, fui até Moscou, peguei meu instrumento e viajei para a convenção", disse Azarkhin.

Sarasate ${ }^{66}$ certa vez disse a Leopold Auer ${ }^{67}$ não ter praticado/estudado durante todo o verão. Davidov, ${ }^{68}$ grande violoncelista de seu tempo, guardava seu violoncelo Stradivarius durante os meses de verão e só retornava a tocar no começo do outono.

Diz Sr. Auer, em seu livro: Violin Playing as I Teach It, que suas mãos eram fracas e que, quando não praticava o violino por dias sucessivos e novamente começa a tocar, sentia que gradativamente perdia a habilidade e ainda menciona que os artistas mencionados são exceção à regra.

O que podemos certamente aprender com as lições do Sr. Auer é que não existe ciência exata a respeito dos limites de: capacidade, fraqueza, virtude ou desempenho de forma homogênea. A régua que mede talentos, absolutamente não é exata, digo, não pode ser medida e valorada para todos, de tal modo que não temos notícia que, no mundo das Artes, dois artistas distintos possuam os mesmos talentos e mesmas virtudes.

Com isso, as dores relacionadas ao instrumento deverão partir de igual princípio; indivíduos com a mesma carga de estudo ou trabalho e apenas um deles desenvolver alguma forma de tendinopatia. Por exemplo, se sentir dor ao executar o instrumento, a mensagem é clara: o corpo relata que algo não vai bem e isso serve como um alerta.

A sugestão é: nunca estude ou trabalhe com dor; a dor é um alerta do corpo para nos recuperarmos e repousarmos. Nunca devemos ultrapassar essa linha,

\footnotetext{
${ }^{66}$ Pablo Martín de Sarasate (Navarra, 1844 - 1908) foi violinista e compositor espanhol do período Romântico. Suas composições, em geral para peças de recital para violino, demonstram grande técnica e interpretação apaixonada.

67 Leopold Auer (In Hungarian: Auer Lipót), (June 7, 1845 - July 15, 1930) violinist Hungaro, professor, maestro e compositor.

${ }^{68}$ Karl Davidov foi um importante Violoncelista Russo do sec. IXX
} 
digo, é muito comum na literatura de nosso instrumento alguns títulos possuírem o enunciado: "se sentir dor, pare imediatamente!"

Em suma, todos esses pontos devem ser considerados porque ilustram a importância da consciência com nosso corpo, enquanto tocamos, e a necessidade de períodos de descanso entre as sessões de prática. ${ }^{69}$

${ }^{69}$ LIEBERMAN, July Lyonn, 3ạ edição, 1995 Revised), pag. IX 


\section{COMO FUNCIONA O PROCESSO INFLAMATÓRIO}

A inflamação é um fenômeno biológico que consiste em reação fisiológica frente a uma agressão que, no caso específico, poderá ser sobrecarga aos limites do corpo ou até mesmo má postura. A inflamação é também fenômeno imunológico, cujas células envolvidas podem ser diferentes, dependendo do local da lesão. Com a alteração da rotina e mudança significativa na posição postural, a reparação do tecido agredido ocorrerá em maior ou menor magnitude, dependendo do dano causado.

Etimologicamente o sufixo "ite" relaciona-se a efeitos inflamatórios, embora os processos refiram-se à musculatura agredida. Por isso, quando nos tendões, são descritos como tendinites; no caso da cápsula articular, como capsulite; nas bolsas sinoviais, como sinovites; na articulação, como artrite; na membrana óssea que recobre os ossos (periósteo), como periostite; denominação complementada pela localização anatômica da estrutura envolvida.

Assim, encontra-se: Tendinite de cotovelo, muito comum nos esportistas que praticam tênis; Bursite de ombro, Tendinite do supraespinhoso e Capsulite de ombro, muito comuns nos músicos contrabaixistas que utilizam o arco Francês; Tendinite de Aquiles e Periostite de Tíbia, como exemplos antiinflamatórios.

Em regra, a prática nos mostra que os fenômenos inflamatórios cursam com dor, "definida como experiência sensorial e emocional desagradável, decorrente de lesão tecidual", sendo esta, de uma maneira geral, o maior motivo das consultas médicas.

Para que ocorra um processo inflamatório entre as estruturas envolvidas no movimento, é necessária a existência de estímulo nocivo de ordem traumática (macrotrauma), microtraumas de repetição, processo infeccioso, alterações metabólicas ou, ainda, uma doença sistêmica.

A evolução à inflamação tem classicamente quatro manifestações principais: rubor, calor, tumor e dolorimento. O rubor provém da maior circulação sanguínea proveniente de vasodilatação. O calor é produzido localmente pela presença de um grande afluxo de sangue quente muito perto da superfície da pele. O tumor ou inflamação é devido às substâncias vasodilatadoras que escapam dos tecidos para os vasos sangüíneos. Dolorimento ou hiperalgesia é proveniente da dispersão de maior quantidade de substâncias algogênicas ao redor da ferida. A dor tem uma causa complexa. A pressão resultante do tumor contribui para a sensação 
de dor, mas não é suficiente para explicar tudo; mesmo que se elimine ou se previna a tumefação, a dor está presente." 70

Demonstradas as possibilidades de inflamações pelo uso excessivo do corpo, seguem algumas sugestões elaboradas por nós, que justamente integram o contexto de otimização em tocar o instrumento.

Se a dor ocorre, algo vai mal. Em grande parte das vezes, é correlata de nosso instrumento e é muito fácil corrigir o problema, de modo que as dores desapareçam, cessada a agressão ao tendão ou músculo.

Em primeiro lugar consideraremos o tamanho físico do instrumento. Se o executante não possuir estrutura física adequada, certamente terá problemas. Por exemplo, um músico com estatura abaixo da média, terá problemas não só para tocar, como também para carregar o instrumento, ainda que o instrumento possua rodas (muito comumente utilizadas) para o transporte. Nossa sugestão, para evitar possíveis lesões ficará a cargo do professor em cuidadosamente examinar o tamanho das mãos e o porte físico do aluno e ajudá-lo a encontrar o instrumento que não o prejudique com o tempo.

Condicionamento é outra particularidade importante, requisito predominante para evitar lesões. A musculatura fraca é mais suscetível a se machucar, e basta pensarmos no contrabaixo para perceber a necessidade de força física para executá-lo. Na verdade, mais do que força, "tônus" muscular, ou seja, quando exercitamos um músculo, ele adquire mais tônus muscular.

É correlato, mas não poderíamos deixar de mencionar, que o condicionamento deve ser tratado com qualidades e habilidades contidas nos esportes e, nesse sentido, além do tônus muscular são aliadas: resistência e flexibilidade.

Desigualdade muscular, ou também chamada desnível muscular, é muito comum nos instrumentos de cordas é mais acentuada no contrabaixo. Isso porque os movimentos gerados pela mão esquerda são praticamente verticais, ou seja, o braço chega a subir e descer paralelamente ao corpo até centenas de vezes diárias dependendo da prática/estudo ou trabalho profissional.

\footnotetext{
${ }^{70}$ Revista de Psicofisiologia, 1(1), 1997
} 
Por outro lado a mão direita executa outro movimento de forma transversal, ou seja, horizontal, ou seja, de forma antagônica à mão esquerda. Então, parece clara a ocorrência de desnível em relação à musculatura das costas, como se alguém praticasse natação, por exemplo, e utilizasse somente o braço esquerdo para nadar. O que ocorreria? A resposta seria que os grupos de músculos seriam mais desenvolvidos em relação àquele que permaneceu na inércia. Esses exemplos comprovam que o músico contrabaixista desenvolve o corpo de forma assimétrica ou desigual, por isso estão mais predispostos a sofrer lesões.

Fatiga muscular é mais uma pretensa causadora da lesão, se não for observada sua real função. Fatiga muscular de forma controlada é usada como meio para adquirir resistência, porque - durante a contração muscular - acontecem processos químicos que, entre outros, fornecem a energia para o trabalho mecânico. Após a contração - portanto durante o relaxamento do músculo - as reservas de energia são novamente reconstituídas. No músculo em trabalho, ocorrem reações liberadoras e as reconstituidoras de energia; em consequência há perturbação do equilíbrio dos processos metabólicos, que se manifestam por diminuição da capacidade de produção do músculo.

Decerto, há uma linha tênue entre os tipos de fatiga muscular; se for para adquirir resistência, deverá ocorrer de forma moderada, pois ultrapassados os limites pode conduzir à cronicidade da dor, por reduzir a irrigação sanguínea e gerar lesão. Como já mencionado por nós, se a dor aparece é hora do descanso e, para os aficionados em exercícios técnicos "tortuosos", sugerimos alongamentos na área afetada e mais tempo de pausa durante os estudos até a resistência/tônus constituirse.

Além dos já suscitados, convém ressaltar fatores extrínsecos, bem como fatores físicos ou emocionais. Físicos, por exemplo, doenças preexistentes que impedem ou limitam a execução do instrumento. É claro que, dependendo da patologia, como é o caso de artrite ou diabetes, apenas para ilustrar, trariam problemas não somente para músico. Para os persistentes é possível contornar algumas doenças preexistentes que venham prejudicar o desenvolvimento das atividades musicais. 
Um dos fatores extrínsecos é o que chamamos de estresse: fator externo e radicalmente afeta a plenitude física e emocional. As primeiras referências à palavra stress, significando "aflição" e "adversidade", datam do século XIV (Lazarus e Lazarus, 1994 citado por Lipp, 1996), mas seu uso era esporádico e nãosistemático. No século XVII, o vocábulo, que tem origem no latim "stringere", passou a ser usado em inglês para designar "opressão, desconforto e adversidade" (Spielberger, 1979 citado por Lipp, 1996). ${ }^{71}$

O estresse tem como resultado a constrição dos vasos sanguíneos, limitando a oxigenação para nervos e músculos. Retomaremos o tema sobre o estresse, quando discorrermos sobre a otimização de performance, pois serão apresentadas sugestões de como minimizar seus efeitos. Em suma, o domínio do estresse e seu monitoramento devem estar presentes em nossas vidas, posto que se convive com essa experiência, desde o início da carreira: na busca de emprego, frente a exames, relacionamentos ou outros desafios da vida moderna.

Igualmente, outra sugestão feita por nós, para evitar lesões ou experiências com as dores relacionadas com 0 instrumento, diz respeito a mudanças. Em qualquer nível que o profissional se encontre, em habilidade ou tempo de instrumento, pode deparar com expoentes da sua área de interesse e, assim, surgirá a pergunta: Gosto muito como " $X$ " toca bem como de suas ideias musicais; logo, quero tocar como "X". Desse modo deveria adotar a mesma postura ou técnica e tentar reproduzir tais ideias. A princípio a postura é boa, porém encontrará obstáculo de ordem prática. Tomemos como exemplo o sistema de posições da mão esquerda em que o executante utiliza o método Simandl, usando para tocar nas regiões graves os dedos 1,2,4 - sistema este que é o mais usado sendo contido na maioria dos livros do instrumento. Entretanto com o seu encanto e vontade de tocar como " $X$ " começa a adotar os sistema 1,2,3,4 (sistema também chamado de técnica de quatro dedos, mão aberta ou extensão) comumente adotado também pelos violoncelistas, para os quais o sistema não tem nome. $O$ terceiro dedo que nunca foi usado no sistema Simandl será deficiente quando tocado.

Toda experiência musical e adquirir uma nova habilidade deve ser tomada com cautela e, ao tentar, prefira ter acompanhamento profissional ao fazê-lo, pois o músico poderá ficar no meio do caminho, isto é, nem conseguir adquirir a nova

\footnotetext{
${ }^{71}$ Revista de Psicofisiologia, 1(1), 1997
} 
habilidade, como perder a já conquistada. Essa situação é muito conhecida com quem muda de escola/método e acaba não conquistando nem uma coisa e nem outra.

Como é nosso de costume, formulamos a sugestão para a tese apresentada. Temos em mente e advogamos que as experiências no campo da música são necessárias, de forma que seus ramos continuam em constante mutação. Todavia, tratando-se de mudanças que refletem na musculatura observamos que devem ser feitas de modo gradual e de forma moderada, assim é nosso entendimento para evitar possíveis experiências dolorosas.

A seguir selecionamos alguns tópicos para a prevenção das dores e das lesões, inspirados no entendimento da violoncelista Janet Horvath ${ }^{72}$;

Aquecimento

O atleta adepto à modalidade de corrida, por exemplo, simplesmente não começa a correr sem alongamento; ele faz alguns aquecimentos que refletem nas articulações e na musculatura. A musculatura aquecida mostra-se mais eficiente, forte e resistente. Se possível, faça uma pequena caminhada, alguns alongamentos e depois disso, de forma vagarosa e tranquila, toque algumas notas no instrumento. É claro que depois de aquecido a musculatura estará mais pronta para as demandas necessárias. Galamian ${ }^{73}$ por sua vez, utiliza o termo desaceleração, sendo muito apreciado por nós. O termo é usado inversamente proporcional ao aquecimento que nos prepara para o trabalho no instrumento, ou seja, depois que o corpo foi exigido com passagens rápidas virtuosas e difíceis; a desaceleração nos prepara para o final do trabalho que termina novamente com os alongamentos.

\section{Faça intervalos}

Faremos menção aos mais diversos tipos de prática tomando como base a experiência de músicos e autores renomados mais adiante, pois cada um possui o seu plano e metodologia de estudo. Nas palavras da Prof.a Horvath, "um intervalo de dez minutos a cada hora de estudo no mínimo é um bom começo para prevenir lesões".

\footnotetext{
72 HORVATH, Janet. Playing less Hurt, 2009 revised edition.

${ }^{73}$ GALAMIAN, Ivan Alexander (1903-1981) foi um grande e influente professor de violino no século XX.
} 
Sempre uma boa postura

Mantenha o peso do seu corpo sempre distribuído de forma igual sobre os seus pés, não importa se você utiliza a postura em pé ou sentada. Se utilizar algum tipo de cadeira que não tenha tratamento ergonômico, certifique-se em deixar os pés de formas iguais. Mantenha a cabeça, sempre que possível, em posição neutra e para isso basta imaginar que ela está amarrada a um fio que a puxa em direção para cima. Uma preocupação necessária é tentar deixar os ombros relaxados, e não torcer ou girar o dorso, ou ficarem inclinados para um dos lados. Esses cuidados também previnem lesões.

Alternativas para reduzir o estresse físico ou mental

Ressaltamos, novamente, que yoga, alongamentos, natação, Alexander Technique e atividades físicas, de modo geral, são atividades preventivas. Elas ajudam a eliminar ou a reduzir as tensões, e de forma conjunta ajudam o corpo a ganhar resistência, força e flexibilidade.

Um dia por semana de descanso sem atividades com instrumento é muito salutar. Faz parte do contexto, lembre-se sempre: músicos, de forma geral, não se dão conta de que existe vida além do instrumento. O descanso é parte importante da prática; além do mais, o ser humano foi desenvolvido basicamente para três ações: luta, fuga e inércia (descanso), durante o qual o ser humano se prepara para lutar ou fugir. Disso, em suma, entendemos a necessidade do descanso como integrante do aprendizado e como coadjuvante para prevenir lesões. 


\section{OTIMIZAÇÃO EM PERFORMACE}

Grande parte dos músicos, contrabaixistas, utiliza a metodologia tradicional, ou seja, Simandl e Billè - independentemente da nacionalidade são os mais utilizados. A aplicabilidade desses métodos é voltada principalmente à prática musical orquestral e em estágios avançados como solista. Entendemos que ambos atendam de forma satisfatória a maior parte do repertório solista/orquestral. Por outro lado, ambos possuem mais de um século, e pelo fato de não possuírem atualizações; trazem sistemas antigos e insuficiência de informações sobre seu conteúdo e metodologia insatisfatória aos dias de hoje.

Simandl utiliza na região grave do instrumento apenas três dedos da mão esquerda que são eles; 1,2,4 (indicador, médio e mínimo) (fig.45) com exceção a região aguda, onde a acrescenta o uso do polegar, denominado como região do capotasto, assim, nesta região, utiliza-se o polegar, indicador, anelar e médio (fig.46) - o dedo mínimo por sua vez, no sistema Simandl não é utilizado na região aguda.

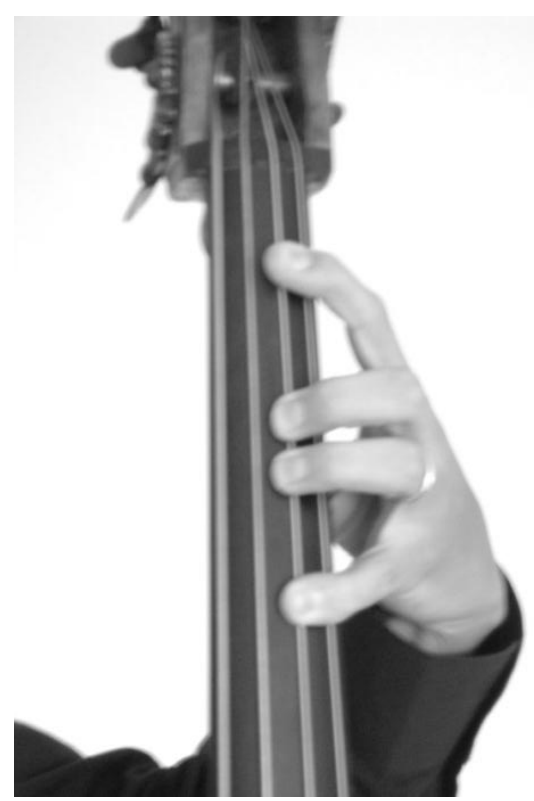

Fig. 45 .

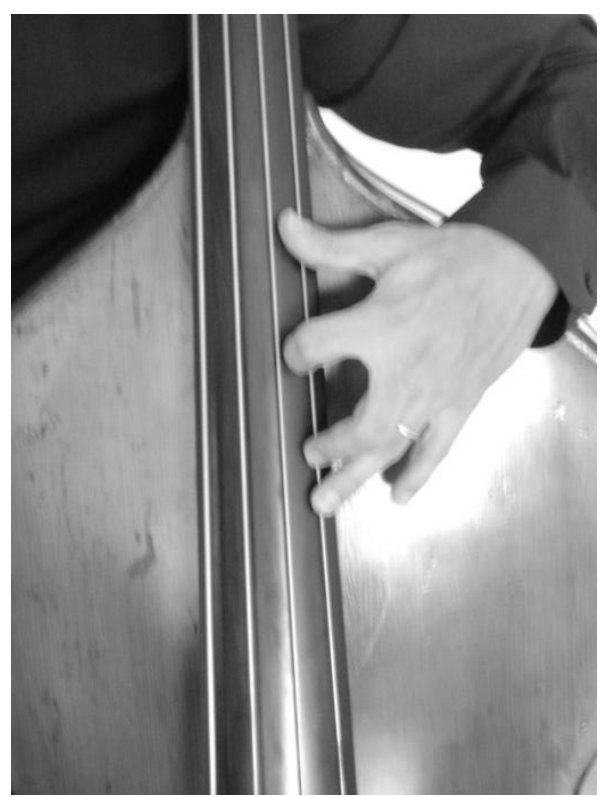

Fig.46.

Billè, de maneira similar a Simandl, utiliza apenas três dedos da mão esquerda. Porém não utiliza o dedo anelar na região grave do instrumento, ficando assim: 1,3,4 (indicador, anelar e mínimo) em vez do dedo médio; no capotasto, utilizam-se o polegar, indicador, anelar e médio - o dedo mínimo por sua vez, no sistema Billè não é utilizado. 
Esses sistemas técnicos, ou maneiras de tocar, funcionam de forma satisfatória em cerca de $85 \%$ a $90 \%$ sobre o repertório orquestral ou ainda mesmo quando se toca jazz ${ }^{74}$. Não apresentam também de forma clara os aspectos de produção de som, os tipos de arco, por quanto tempo estudar e o quê estudar, em seu conteúdo; apenas para demonstrar algumas deficiências.

Da mesma forma que evidenciamos posturas e maneiras de segurar o instrumento, demonstraremos de forma comparada o que entendemos ser a tendência do contrabaixo moderno.

Dissertaremos sobre dois tipos de arco usados pelos contrabaixistas: o arco alemão e francês. Faremos considerações e distinções sobre ambos e confrontaremos de maneira crítica as principais diferenças. A produção sonora e os aspectos físicos do arco em relação às cordas serão também abordados.

A técnica usada na execução do manuseio do arco, a qual denominamos desde já como "técnica de mão direita" será tratada de forma prática e reforçada com exercícios formulados pelo autor, serão apresentadas as mais variadas maneiras de segurá-lo.

Similar ao que foi explorado de forma comparada, ao longo deste trabalho, a abordagem da técnica de mão esquerda, utilizada para apertar as cordas e definir a altura da nota, demonstrará várias escolas e seus princípios metodológicos, bem como alguns de seus principais expoentes.

No capítulo Estudo ou Prática do instrumento, tentaremos suprir o que, do nosso ponto de vista, são deficiências dos manuais de contrabaixo. Os manuais parecem-nos mais um poderoso remédio, sem bula de instruções.

Se tomarmos, por exemplo, o método Simanld que contém estudos sobre posições, escalas e arpejos, só possui informações estritamente musicais, deixando para trás aspectos importantes sobre o quê estudar, quanto estudar, o tamanho do arco a ser utilizado, que em nossa linguagem técnica quer dizer quanto de arco é usado para pressionar a corda e em quais vãos, do talão à ponta do arco.

\footnotetext{
${ }^{74}$ GALE, B. Thomas, Technical Foundation Studies for Double Bass V. I.
} 
Desse modo, antes de falarmos da prática propriamente dita, dissertaremos sobre a nossa máquina pensante, isto é, nosso cérebro. Todo silogismo necessário à almejada performance ideal começa lá e certamente entendemos que músicos, de modo geral, necessitam conhecer de modo satisfatório essa área. Precisamos que nossa memória e nosso raciocínio funcionem de forma otimizada, pois certamente em nossa vida acadêmica e profissional será exigido que memorizemos nosso repertório. 


\section{ARCO ALEMÃO X ARCO FRANCÊS}

Ao compararmos cantores com instrumentistas de cordas (violino, viola, cello e contrabaixo), poderíamos concluir que o arco, ao friccionar as cordas, representa a quantidade de ar produzida pelos pulmões do cantor. ${ }^{75} \mathrm{E}$, nesse mesmo sentido, aos instrumentistas de sopros, o arco é, guardadas certas proporções, a nossa "coluna de ar".

Sobre o arco, há mais de duzentos anos, Leopold Mozart escreveu:

O arco dá vida às notas... produz ora modesto, ora impertinente, ora um tom sério ou brincalhão, ora adulação, ou grave e sublime, ora uma melodia triste ou alegre, e por meio de seu uso racional, somos capazes de resgatar e despertar emoções.

Desenvolver boa técnica de arco é uma arte muito mais complexa do que a mão esquerda ${ }^{76}$. Os elementos: bom fraseado, articulação, intensidade, crescendo, decrescendo - apenas para citar alguns - são algumas das diversas nuances produzidas pelo arco, responsável primário pela produção sonora, ou seja, inquestionavelmente o arco é a alma do contrabaixo.

Por outro lado, o progresso de aprendizado da mão esquerda é mais rápido, pelo fato de a maioria dos métodos de contrabaixo, salvo exceções, não se dedicarem ao seu efetivo estudo. Muitos músicos, por possuírem aparentemente uma considerável proficiência e agilidade com a mão esquerda, esquecem-se de que o responsável principal do som é o arco, ou seja, tudo começa lá. E o resultado dessa equação será a dificuldade de tocar passagens lentas com qualidade sonora satisfatória e até mesmo a execução de movimentos e golpes primários de arco.

$\mathrm{O}$ arco deve ser tratado como um instrumento independente, tanto que $\mathrm{O}$ contrabaixista francês Fraçois Rabath utiliza o termo "desassociar"77, quando se refere ao estudo das mãos de forma independente, isto é, desassociar a mão direita da esquerda. Mesmo que a passagem ou trecho musical use ambas as mãos, estuda-se de forma separada e, ao final, associam-se as duas mãos.

\footnotetext{
${ }^{75}$ GOÏLAV, Yoan, The Double Bass - A PHILOSOPHY OF PLAYING, p. 12.

${ }^{76}$ GERLE, Robert. The Art of Bowing Pratice.

${ }^{77}$ RABATH, François. The art of bow.
} 
Tendo em vista a pouca atenção ao estudo do arco, a técnica será debilitada no que concerne a volume, articulação, diminuendos não desejados, entre outros.

Concluímos que a boa técnica de arco não é apenas a habilidade de extrair o som do instrumento com muito volume de som e a execução de passagens rápidas. Faz-se necessário incluir qualidades como expressão e interpretação como parte essencial na execução musical.

O primeiro e último objetivo do arco é criar expressão musical através do som. Nesse sentido, é necessário o completo domínio técnico de forma satisfatória para atender as necessidades que a obra musical exige. No caso dos contrabaixistas, por origens históricas, temos a opção de utilizar dois tipos de arcos: o Francês (fig.47) e o Alemão (fig.48). No cenário musical muito se tem dito sobre a distinção entre eles e, na opinião dos autores, ambos possuem pontos positivos e negativos como ilustraremos adiante.

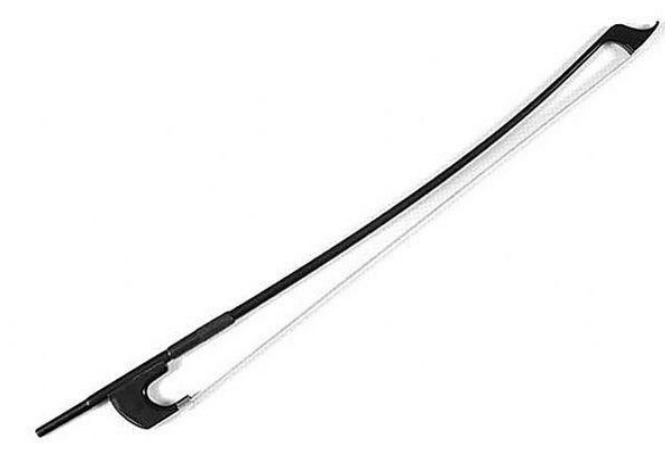

Fig.47.

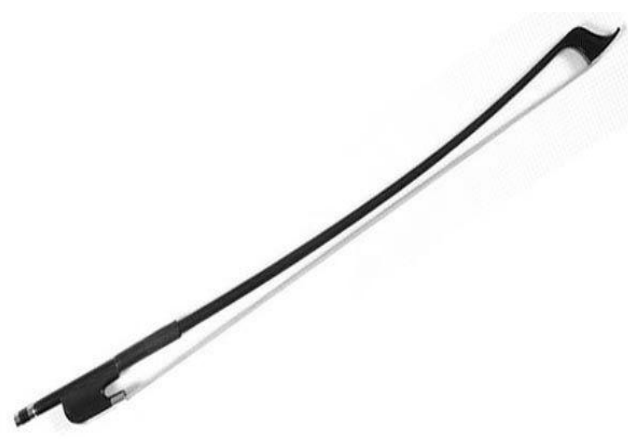

Fig.48.

Antes de apresentar as mais variadas maneiras e posturas em segurar os arcos, faremos algumas considerações de funcionais sobre eles.

Pela óptica mecânica, o arco funciona de forma similar ao sistema de alavancas, ou seja, como barras rígidas que giram em torno de um ponto fixo, quando uma força é aplicada para vencer a resistência. A vara, vareta ou baqueta do arco fica sobre $(P)$, que é chamada de área de apoio, responsável pelo pivô. A força provocada por $(F)$ é efetuada pela pronação e esta, por sua vez, encontra resistência $(R)$, fazendo as cordas vibrarem. Em contrapartida, quando o arco é retirado fora da corda, ou seja, encontra-se no ar, seu peso está em $(C)$. Por certo, qualquer forma de utilização do arco, Alemão ou Francês, percorrerá este esquema: 


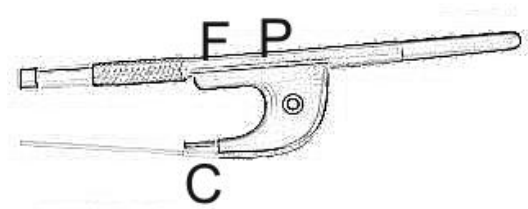

Fig. 49.

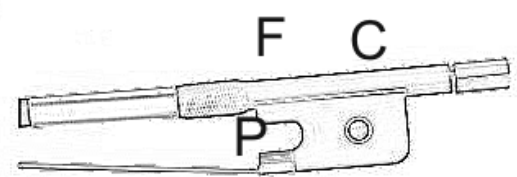

Fig.50.

No momento em que o arco é retirado da corda, isto é, na fase de preparação para o encontro da corda, há algumas diferenças entre o arco Alemão e o Francês. O ponto $(R)$ é substituído pelo contrapeso como dito acima por (C).

Por outro lado, no arco Alemão, quando retirado da corda em fase de preparação, o ponto $(\mathrm{R})$ é substituído por $(\mathrm{C})$, com isso pelo princípio da alavanca o arco é supinado, em geral, pelo dedo mínimo ou pela parte palmar da mão.

Visualmente os arcos apresentam apenas diferenças estéticas. A principal delas está no talão que, em realidade, é o diferencial. No arco Alemão, o talão é maior em relação ao Francês. Neste, quando se manuseia, o talão fica fora da mão; no Alemão, dentro da mão. Em relação à execução, ambos possuem produção sonora idêntica, que é vibração que resulta do atrito entre a crina e a corda. A única diferença realmente significante é em relação ao esquema acima, quando o arco se encontra dentro ou fora da corda; i.e. na produção de som ou em fase ativa.

Em síntese, entendemos que as duas escolas podem obter os mesmos resultados na produção sonora. Apesar de métodos, escolas e maneiras distintas de segurar ambos os arcos.

Assim, tal qual os conceitos do Prof. Yoan Goilav, traçamos um paralelo entre as duas escolas de arco:

\begin{tabular}{|l|l|}
\hline Arco alemão & Arco francês \\
\hline $\mathrm{P}=$ base do polegar ou falange & $\mathrm{P}=$ ponta do polegar ou falange \\
\hline $\mathrm{F}=$ dedo médio assiste o indicador & $\mathrm{F}=$ dedo indicador assiste o médio \\
\hline $\mathrm{C}=$ dedo mínimo & $\mathrm{C}=$ dedo mínimo \\
\hline
\end{tabular}


Além dessas diferenças, sobre as posições posturais, há diversas formas de segurar/manusear ambos os arcos. Pensamos ser importante ter conhecimento sobre esses princípios mecânicos, pois a partir do momento de reflexão sobre eles será mais fácil identificar problemas técnicos e pontos fracos, que ajudem a aperfeiçoar as técnicas de arco.

Do esquema apresentado, podemos observar que o sistema de alavancas proporcionado por $\mathrm{P}$ e $\mathrm{F}$, quando se utiliza o arco Alemão, é maior que o Francês. Isso ocorre porque o comprimento da vareta ou baqueta do arco Alemão é maior que o outro; consequentemente há mais "torque" em seu sistema, em especial na região da ponta do arco.

Por outro lado, no arco Francês, o ponto $(\mathrm{P})$ muito próximo do centro de gravidade do arco, oferece mais controle sobre o arco em passagens virtuosas, principalmente as que envolvem cruzamentos de cordas, por exemplo, no golpe de arco conhecido como "bariolage" .

Há diversas formas e maneiras de segurar o arco Alemão que levam à denominação da escola ${ }^{78}$. Sobre a mais comum, popularmente chamada de "Tcheca", faremos comentários sobre outras formas de posturas em segurar o arco. Embora boa parte dos contrabaixistas utilizem esse termo, em encontro nosso com o contrabaixista tcheco e professor Miroslav Gadjos, ele relata que a terminologia é equivocada, pois deveria se chamar escola alemã. Segundo ele, a Tchecoslováquia foi muito influenciada e estava sob o domínio da Alemanha, na época de fundação do Conservatório de Praga em 1808, ou seja, ainda não era o que conhecemos hoje como Tchecoslováquia. $O$ conservatório, além de figurar entre as escolas mais antigas da Europa, foi fundado com a intenção de dar ensino e treinamento aos músicos de orquestra.

Decerto, entendemos que a postura denominada "theca" é atribuída a Simandl, por seu livro; Novo Método Para Contrabaixo, amplamente difundido por todo o mundo, cujo conteúdo traz fotos ilustrativas de como segurar o arco Alemão.

\footnotetext{
${ }^{78} \mathrm{O}$ termo escola é o conjunto técnico usado pelo instrumentista em sua execução. Cada contrabaixista adota a escola ou método de execução que mais lhe adéqua. Há também os que adquirem a metodologia herdada simplesmente por seus professores, na qual somos contrários pelo fato que a melhor metodologia em nossa opinião é a que mais se adéqua ao individuo.
} 
Simandl estudou em Praga, nasceu na cidade de Blatna, hoje República Tcheca, e foi importante professor de contrabaixo, lecionando no Conservatório de Viena de 1869 a 1910.

A posição básica em segurar o arco Alemão é similar ao de segurar um lápis ou caneta. A vareta é segurada de forma que esteja entre o polegar e o dedo indicador (fig.51). A falange distal do polegar repousa na parte de cima da vareta do arco, (muito comum nos Estados Unidos). O polegar se estende sobre a vareta do arco e usando como pronação a primeira ou segunda falange..$^{79}$

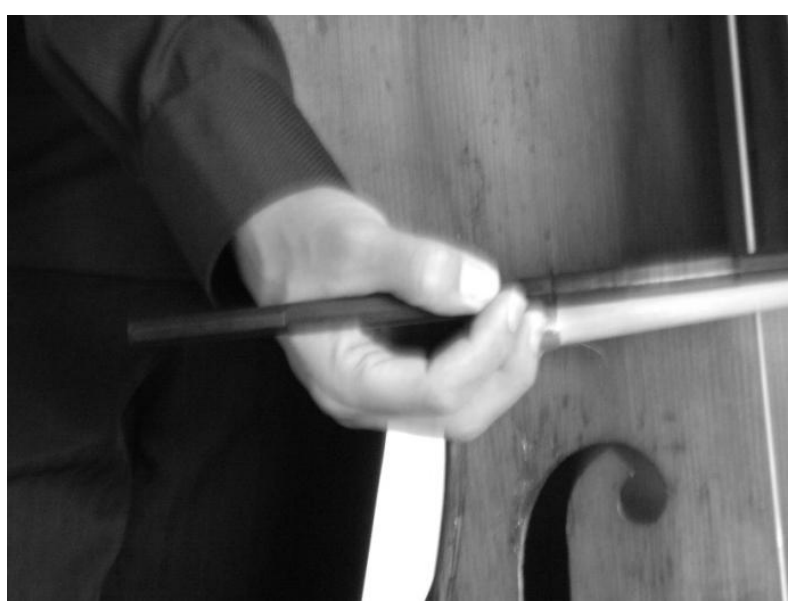

Fig. 51.

Os desdobramentos dessa posição básica de segurar o arco Alemão e suas probabilidades são interessantes; mesmo que não seja utilizada pelo músico, seu conhecimento é indispensável. O que é realmente importante é o entendimento mecânico, ou seja, o funcionamento e a aplicabilidade nos mais diversos estilos musicais.

Outra maneira, utilizada na Europa principalmente (fig.52), segue os mesmos moldes da posição básica com uma diferença: a falange, em contato com a vareta do arco, é a proximal com o dedo indicador e com a falange distal, ajudando o polegar a pronar o arco na corda. Essa maneira de segurar o arco foi usada por Ludwig Streicher, contrabaixista austríaco e professor da escola de Viena. Um detalhe utilizado pelo Professor Streicher é como trata as expressões na aplicação da gradação dinâmica entre pianíssimo, piano e fortíssimo.

\footnotetext{
${ }^{79}$ BRADETICH, Jeff. Double Bass - The Ultimate Chalenge. 2009, pag. 18.
} 


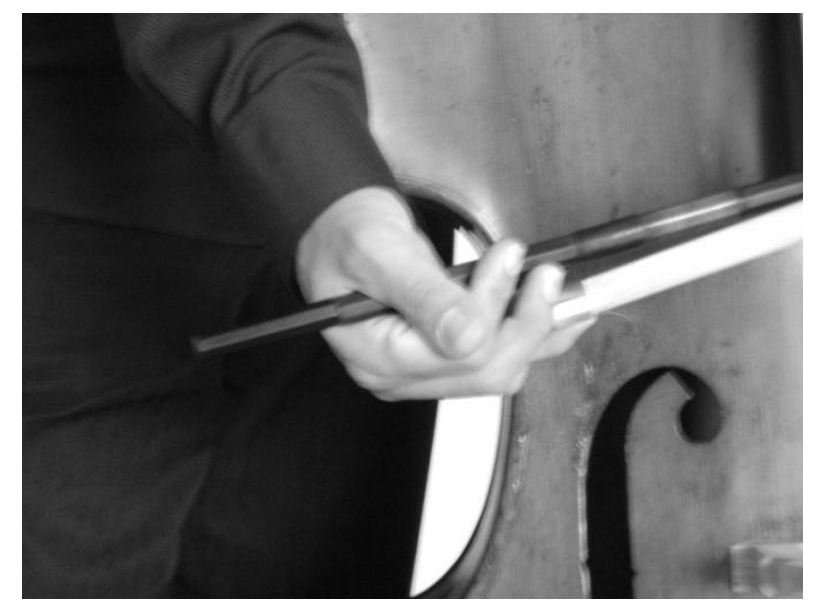

Fig.52.

Para tocar a gradação dinâmica, pianíssimo, utilizam-se apenas dois dedos da mão direita: o dedo mínimo com a falange distal e o dedo médio, também em sua falange distal; desse modo, os dedos indicador, anelar, e polegar assumem a posição passiva e não permanecem de forma direta em contato com o $\operatorname{arco}^{80}$

Ao contrário, quando se deseja produzir a gradação dinâmica, forte ou fortíssimo, utilizam-se os dedos indicador, médio, anelar e polegar de maneira ativa. Enquanto o dedo mínimo é retirado, não há efeito opositor à força de pronação de todos os dedos, para atingir a dinâmica desejada.

Outra diferença marcante na maneira de segurar e executar o arco é que alguns métodos usam a flexão palmar e dorsal, ou seja, utiliza-se o pulso para mudar a direção transversal do arco. A flexão palmar é usada, quando tocamos uma nota com o arco para baixo, o arco movimenta-se da esquerda para a direita em sentido ao talão; e de forma contrária, da direita para a esquerda, é usada a flexão dorsal, quando tocamos no sentido à ponta do arco. Note-se: ambas as flexões são frequentemente mais usadas por escolas da Europa, todavia as escolas russas e americanas usam essas flexões de forma mínima.

Escolas, que usam a flexão palmar ou dorsal com amplitude maior de movimento, defendem os mesmos movimentos que os violinistas executam quando o arco muda de direção. Esse movimento seria o momento preparatório para o arco de forma transversal mudar de direção. Em suma, a flexão palmar é o impulso em direção contrária ao trajeto do arco.

\footnotetext{
${ }^{80}$ STREICHER, Ludwig. My Way of Playing the Double Bass Vol 1.
} 
A escola russa, por exemplo, usa de forma mínima o pulso nas flexões. $O$ argumento é que, ao executar a flexão do pulso, a pressão feita pela crina na corda será retirada obrigando o músico a realizar a pressão novamente. Assim, alguns músicos preferem não usar (ou minimizam) as flexões evitando o movimento.

Um ótimo exemplo é como Gary Karr muda a direção do arco para o talão. $\mathrm{Na}$ mudança de direção, ele acompanha o movimento cilíndrico da corda. Ao tocar a corda Sol com o talão, a pressão na corda fica na direção lateral do contrabaixo. Ao começar pela ponta do arco, ele ficará mais próximo da corda Re. Igualmente, quando se toca a corda Re com o talão, o arco fica próximo a corda Sol; ao contrário, próximo a corda La. No mesmo sentido, com as cordas La e Mi.

Das diversas formas de segurar o arco Alemão, os princípios mecânicos são os mesmos havendo algumas variações como ilustramos e comentamos abaixo (fig.53 a 58):

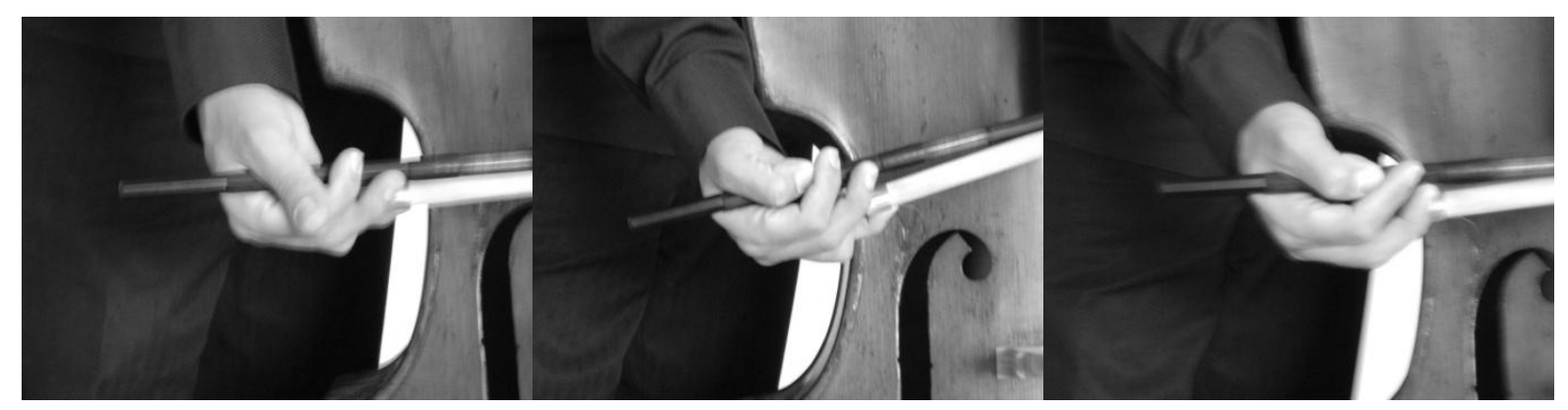

Fig.53.

Fig.54.

Fig.55.

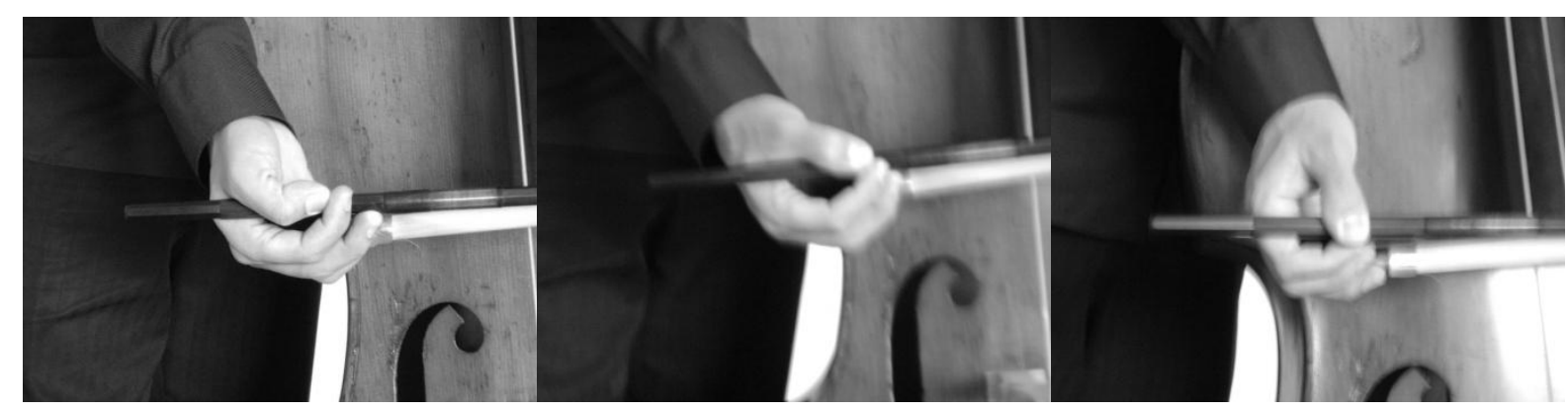

Fig.56.

Fig.57.

Fig.58. 
A maneira de segurar o arco Francês possui três pontos essenciais de contato e controle: o dedo indicador, dedo mínimo e o polegar ${ }^{81}$.(fig.59 a 66)

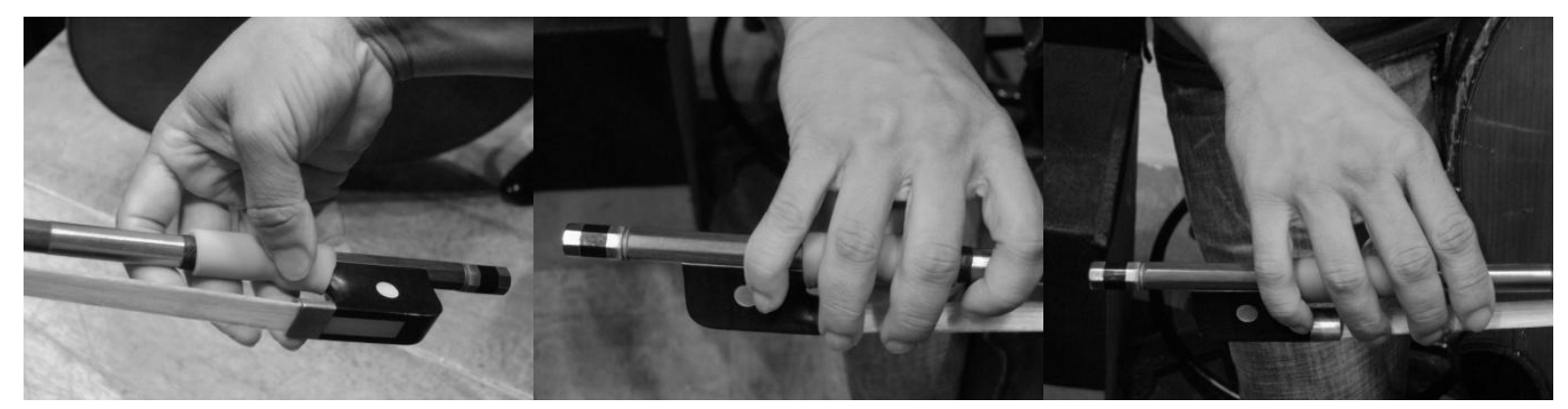

Fig.59.

Fig.60.

Fig.61.

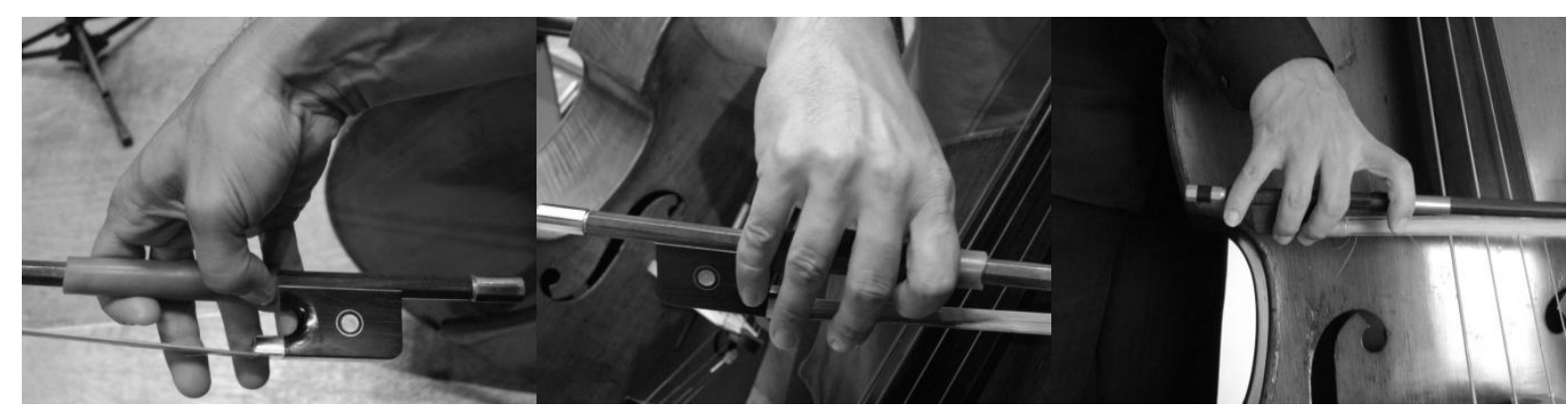

Fig.62.

Fig.63.

Fig.64.

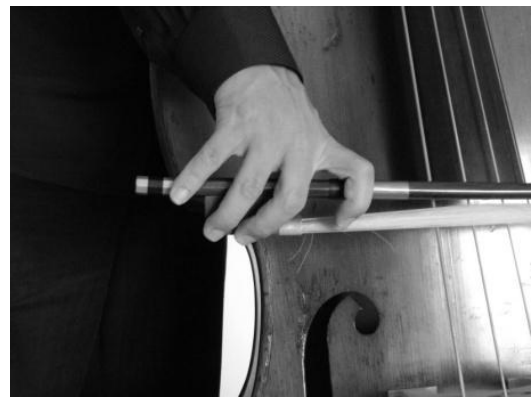

Fig.62.

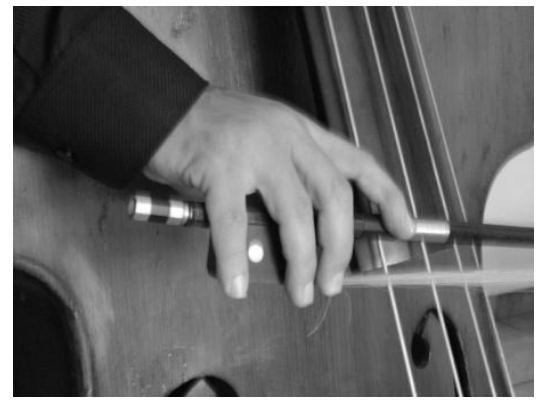

Fig.63.

Dedo indicador: o dedo indicador da mão direita deve ser colocado sobre a vareta do arco entre a primeira e segunda falange.

Dedo mínimo: deve ser colocado na região do talão. Observe-se que não é adotada a mesma maneira como se segura $\mathrm{o}$ arco do violino e sim colocando o dedo sobre o arco com as falanges média e proximal do dedo mínimo. Aos arcos que possuírem o adorno de madreperola, comumente chamado de olho de madrepérola, é um bom ponto de referência para o posicionamento dos dedos.

\footnotetext{
${ }^{81}$ BRADETICH, Jeff. Double Bass - The Ultimate Chalenge. 2009, p. 15.
} 
Dedo polegar: deve ser colocado de forma curvada em um dos dois pontos. Na própria vareta, fazendo força contrária ao talão; ou mais para dentro do talão; ou até mesmo em sua quina, que é a parte lateral da vareta do arco.

A função do polegar é opositora, ou seja, antagônica com o dedo indicador e o mínimo. O indicador transfere a ação de pronação do antebraço para a vareta do arco. Essa pronação não deve ser produzida de forma a pressionar apenas o dedo indicador, pois sua real intenção é conduzir a pronação diretamente do antebraço.

O dedo mínimo possui as mesmas características do indicador e atua com efeito opositor ao polegar, produzindo o sistema de alavanca. O dedo mínimo transmite a força contra a corda, diminuída pela ação do polegar opositora, que é responsável pela diminuição do peso do arco na corda. O peso, por usa vez, é responsável pelas gradações dinâmicas, piano e pianíssimo, principalmente no talão e no ponto de equilíbrio do arco.

Outra característica do arco Francês são os movimentos de abdução e adução do pulso. Tal qual como no arco Alemão, o pulso é responsável pelas mudanças transversais de direção do arco. Então, usa-se a abdução, quando tocamos notas em sentido ao talão; e, de forma contrária, a adução, quando tocamos notas em sentido à ponta do arco.

Diferentemente do arco alemão, o arco francês não possui muitas variantes para serem demonstradas e na maioria das vezes a variação é mínima. Isto é, o modo de segurar o arco é derivado da maneira usada por violinistas e violoncelistas e a variação está na em um dos três pontos essenciais de contato e controle: o dedo indicador, dedo mínimo e o polegar.

Apesar da grande diferença da postura da mão em segurar/executar um arco ou outro, a função mecânica dos dedos e pulso são similares. A diferença primária é a relação de alavanca e a pronação. Os dedos contribuem para a pronação do arco contra a corda; e os movimentos de adução, abdução, flexão palmar e dorsal seguem os mesmos princípios. No arco Alemão, a pronação é proporcionada (dependendo do modo postural) pelo dedo indicador ou polegar; muitas vezes com ambos os dedos. De forma opositora, no arco Francês, o polegar é usado para supinar o arco, enquanto o dedo mínimo prona o arco contra a corda. 
Entendemos que, da mesma forma que o músico pode executar o instrumento em ambas a posições posturais em pé ou sentado, também pode utilizar ambos os tipos de arcos. É claro que pode haver predileção por parte do executante, mas a prática do arco não habitual provocará fortalecimento dos músculos não utilizados pelo outro, o que otimiza a técnica. Como já demonstrado, dependendo da postura adotada em segurar o arco, alguns dedos assumem inércia e, consequentemente, terão menos força pelo desuso. Assim, mesmo que prefira um dos arcos, o estudo eventual do arco Francês (para quem toca o arco Alemão) ou vice versa será extremamente benéfico e aconselhável.

Existem algumas orquestras que não permitem aos contrabaixistas tocarem com o arco Francês - caso de orquestras como a Filarmônica de Berlim, na qual aliás o músico nem pode concorrer a uma vaga. Talvez por influência de alguns músicos que estudaram na Alemanha, esse fenômeno também acontece aqui no Brasil, na OSESP - Orquestra Sinfônica do Estado de São Paulo, que só permite arcos alemães no naipe de contrabaixo

De outro modo, na França, o predominante é o arco Francês, como é o caso da Orquestra Nacional da França.

$\mathrm{Na}$ Filarmônica de Nova York, o naipe de contrabaixo utiliza tanto o arco Francês quanto o Alemão. Entendemos que essa heterogeneidade é a mais acertada, pois a qualidade do instrumentista não está ligada diretamente ao arco que toca. É notório que essa flexibilidade não subtraia qualidade, principalmente em se tratando da Orquestra Filarmônica de Nova York, fundada em 1842. Eugene Levinson, ${ }^{82}$ além de ser o primeiro contrabaixo da orquestra, também é professor na Julliard School, que utiliza 0 arco Alemão. Orin O'Brien, ${ }^{83}$ também principal contrabaixo na orquestra e professora na Julliard School, utiliza o arco Francês.

\footnotetext{
82 Eugene Levinson goza de uma única carreira como solista de classe mundial e como principal Bass da Filarmônica de Nova York desde maio de 1985, além de ser um dos principais e professores de renome mundial contrabaixo. (http://nyphil.org/meet/orchestra/index.cfm?page=home)

83 Orin O'Brien nasceu em Hollywood de pais que trabalhavam na indústria cinematográfica, George O'Brien e Marguerite Churchill, e recebeu seu primeiro treinamento musical em Los Angeles, onde estudou com Milton Kestenbaum e Reinshagen Herman. , O'Brien então, estudou em Nova York com Frederick Zimmermann e graduou-se na Juilliard School. Ela tem sido um membro da Filarmônica de Nova York desde 1966, onde trabalhou com principais regentes do mundo.
} 
Orquestras, que preferem apenas um ou outro arco, argumentam que a escolha se dá pela homogeneidade, posto que a diversidade gera antagonismo, isto é, destoa do resto do grupo, já que os arcos possuem sonoridade diferente.

Discordamos totalmente dessa opinião, pois só pode existir motivo plausível se for bom motivo musical sobre o assunto. Quem toca com proficiência adequada em afinação, execução, estilo e sonoridade está acima de qualquer predileção ou gosto.

A Filarmônica de Nova York por ser escola musical produto da emigração de europeus e, assim, produz um mix cultural. Aliás, uma das bandeiras hasteadas por nós é tal qual como ocorre nos esportes, o chamado MMA - "mix martial arts", onde os praticantes adotam mais de uma modalidade de competição. O resultado disto será um atleta completo e parafraseando o MMA, temos em mente ser esta a tendência não só para a música como também para qualquer segmento social.

Rodion Azarkin ${ }^{84,}$ quando perguntado sobre isso responde: "Na orquestra eu posso tocar tanto com o arco Alemão ou Francês, isso dependerá da preferência do maestro. Eu, é claro, prefiro o arco Alemão. O arco Francês é para refinamento, o alemão é para 'força'."

Em sentido contrário, Yoan Goïlav afirma: "De forma contrária a que as pessoas imaginam, sinto que o arco Francês tem mais volume, enquanto o arco Alemão dá ao instrumento mais timbre."

Assim, apesar da predileção até do próprio professor, o músico deverá ser o responsável pela escolha do arco principal. Essa escolha também está relacionada com a estrutura física do indivíduo. Contrabaixistas com braços curtos podem beneficiar-se com o arco Francês, pois com ele é possível deixar o braço com mais amplitude. Inversamente proporcional, o arco Alemão - para os que possuem braços longos.

Em linhas finais, devemos considerar que há duas linhas de pensamento em relação ao contrabaixo acústico e os arcos. Se considerarmos o instrumento moderno e consequentemente próximo ao violoncelo, prioriza-se o uso do arco Francês. De outro modo, aqueles que desejam distanciar-se do violoncelo tendo em

${ }^{84}$ STROKES, Donovan. A Rough Guide to the life of Rodion Azarkin - 1999. 
mente uma sonoridade mais voltada para o violone, parente mais próximo da viola da gambá, foca-se o arco Alemão.

A técnica de arco, ou o modo técnico de conduzi-lo à produção sonora, não apenas se restringe à maneira de segurar o arco Francês ou Alemão. Essas maneiras são apenas algumas das muitas variáveis de seu objeto. Aliás, são elas que distinguem um intérprete do outro: alguns usam o ponto de contato do arco com mais proximidade do cavale, outros mais perto do espelho. Acontece a mesma coisa com a retomada de arco: alguns na retomada de direção do arco em notas longas aceleram a velocidade do arco e mudam a trajetória; outros apenas acompanham o contorno da corda para essa mudança.

Por exemplo, a corda D, solta, começando pelo talão tendo em mente deixar o arco de forma próxima da corda mais aguda, que neste caso é a corda G, e ao chegar à ponta do arco, quando ocorrerá a mudança de trajetória do arco, o executante apenas usa o auxílio do braço ou pulso; de forma inversa, o arco ficará mais próximo da corda grave, no caso a corda $A$.

O mecanismo do arco que leva as cordas a vibrar é conhecido como stickslip. "Cola e desliza" é a melhor tradução, pois o stick-slip é causado pela alternância entre superfícies que colam umas às outras ou deslizam umas sobre as outras, com a correspondente alteração na força da fricção. Basicamente a vibração da corda é de forma alternada contra o trajeto do arco. A primeira fase (stick) ocorre, quando a crina do arco com a resina "gruda" na corda, ou seja, será o ponto inicial do arco e produzirá som, enquanto houver tensão, energia cinética que provoque a vibração cedendo à força contrária. A segunda fase (slip) ocorrerá com a trajetória do arco, isto é, seu deslizamento faz a corda vibrar em sentido oposto ao trajeto do arco. Terminada a trajetória do arco, quer dizer, quando o arco chegar à região da ponta, a retomada para o talão dará início a um novo ciclo de stick-slip.

A notação musical não consegue fornecer em 100\% informações que traduziriam uma obra a ser tocada por qualquer inteéprete de forma exatamente igual, provavelmente isso torna a arte musical sui generis. A interpretação cabe à experiência musical do executante no que tange a: estilo, estética, conhecimento sobre a obra, proficiência técnica. Não é possível sequer ao mesmo intérprete executar uma obra duas vezes de forma exatamente igual. 
Exemplificamos de outra maneira: não podemos comparar músicos como Gary Karr e Francesco Petrachi - apesar de ambos serem solistas e professores renomados internacionalmente, ao tocarem a mesma música com metodologias próprias e predileções musicais inerentes. Ou seja, essas variantes ficam a critério do executante. É nesse momento que entra o bom gosto do intérprete que usa os recursos, tal qual um pintor utiliza a paleta de cores para dar vida a sua pintura.

E mesmo no que ser refere à nomenclatura dos golpes de arco, sendo diversa dependendo de cada região geográfica, é importante lembrar que, se usarmos em sentido estrito a nomenclatura de violino, poderemos nos equivocar e explicaremos por quê. Ao levar em consideração o tamanho do violino e seu arco é evidente a desproporcionalidade na comparação entre o tamanho do contrabaixo acústico com seu arco.

Em realidade existem seis grupos básicos de golpes de arco que podem ser agrupados em três pares de acordo com suas características musicais ${ }^{85}$ :

- Detaché e Legato - arco na corda, notas longas com seu valor real.

- Martelé e Staccato - arco na corda, notas curtas, duração sonora com metade de seu valor real.

- Spiccato e Ricochet - arco fora da corda, soando duração sonora com metade de seu valor real.

Diante de nomenclaturas diversas de alguns autores, pensamos que a melhor definição em relação à técnica de arco e suas variações, que traduz a natureza e a aplicação da mão direita entendida por nós, é a utilizada pelo Prof. Klaus Trumpf ${ }^{86}$, abaixo transcrita similarmente em seus moldes.

I - Detaché (Fr.) termo francês usado para arco separado e que não dever ser confundido com a versão em inglês detached, que quer dizer espaço entre as notas. O detaché é o principal golpe de arco usado nos instrumentos de corda e comporta os mais diversos estilos, o que depende das diferentes velocidades e pressões sobre a baqueta do arco que pode expressar audíveis diferenças, tal qual relacionamos à paleta do pintor e são eles:

\footnotetext{
${ }^{85}$ GERLE, Robert. The Art of Bowing Pratice.

${ }^{86}$ TRUMPF, Klaus - Kontrabass-Bogen Technik.
} 


\begin{tabular}{|l|l|}
\hline Grand detaché & Grande golpe de arco, com todo arco partindo do talão a ponta. \\
\hline Petit detaché & $\begin{array}{l}\text { Golpe com pouco arco (geralmente não passando de } 5 \mathrm{~cm} \text { de } \\
\text { tamanho de crina utilizada). }\end{array}$ \\
\hline Detaché secco & $\begin{array}{l}\text { Golpes curtos com velocidade de arco, ou seja, mais tamanho de } \\
\text { arco (muito comum na escola germânica). }\end{array}$ \\
\hline Detaché elastic & Golpe de arco com elasticidade. \\
\hline Detaché prononcé & $\begin{array}{l}\text { Golpe de arco ligeiramente acentuado com boa pronúncia das } \\
\text { notas. }\end{array}$ \\
\hline Legato detaché & $\begin{array}{l}\text { Golpe de arco em que as notas são ligadas de forma quase } \\
\text { imperceptível com apenas uma direção, ponta ou talão do arco. }\end{array}$ \\
\hline
\end{tabular}

II - Legato (it.). A ligadura, ou seja, tocar as notas de forma ligada de maneira que o arco, com apenas uma direção (ponta o talão), ligue uma ou várias notas. No contrabaixo há possibilidade do legato também entre as cordas, mas para isso deverá unir mão direita, braço e antebraço com movimentos verticais para atingir a corda grave ou aguda.

III - Staccato (it.) O termo é usado para notas curtas. Para instrumentos de cordas o staccato é ilustrado com um ponto acima ou abaixo da nota designa um tipo de articulação no qual as notas e os motivos das frases musicais devem ser executados com suspensões entre elas, ficando as notas com curta duração.

IV - Portato (it.). O termo é usado quando o arco executa notas individuais de forma a dar ênfase sobre cada uma delas primando pela não interrupção do som.

V - Martele (fr.) martellato (it.). Arco com movimentos rápidos, seguido de descompressão do arco na corda a cada golpe. Usado para passagem. Atenção deve ser dada a esse golpe, pois o arco deve ser pressionado contra a corda, antes da produção sonora; a descompressão ou relaxamento do braço, pulso e dedos ocorre no momento em que a nota é tocada. O valor da nota é reduzido, ou seja, curta com pequenas pausas individuais em cada nota, característica principal desse movimento.

VI - Spiccato (it.) = claro e separado. O spiccato denota a maneira como o arco é usado e sua principal característica é sair da corda, após atingir cada nota. Diferenças e variantes são determinadas pela posição do arco em relação à corda, isto é, ângulo e altura. No spiccato o movimento do braço determinará o tipo predominante, vertical ou horizontal; Spiccato horizontal - a melhor descrição desse tipo de arco é pensar em uma raquete de pingue-pongue. Não é arremessado contra a corda, porque permanece na mão do executante; Spiccato vertical - nesse tipo de golpe de arco, basta imaginar que o arco "cai" sobre a corda. O nome é autoexplicativo, basta levantar ou tirar o arco da corda e o peso realizará o movimento.

VII - Sautillé (fr.) saltato (it.). Esse golpe denota a forma rápida do spiccato cuja flexibilidade da vareta é explorada. O impulso é dado tendo em mente pressionar a curva da madeira que refletirá diretamente na crina. A distinção entre spiccato e sautillé é que, neste último, o arco não é retirado da corda. É frequentemente usado para passagens rápidas. 
VIII - Ricochet (fr.) Jeté (fr.) Para nós, muito se assemelha com o spiccato vertical. A diferença está em que o arco toca um grupo de notas em mesma direção, do talão ou arco, com um só golpe. Ests arco também é conhecido como staccato volante ou flying staccato.

Os aspectos em relação a pressão e ponto de contato, exercidos pelo arco contra a corda, terão efeito sobre o timbre e a região na qual o músico tocará. Ao tocar o arco, próximo ao cavalete, é obtido um som cortante ou estridente e, proporcionalmente inverso, quando o arco é tocado mais próximo ou em cima do espelho, extrai-se som mais escuro. Ou seja, a relação entre grave e agudo também é estabelecida pelo ponto de contato, que é a região entre 5 centímetros antes do final do espelho do instrumento e vai até antes madeira do cavalete. Sempre que possível, o arco deverá estar paralelamente em relação ao cavalete, isso se dá por causa da construção da corda em relação às cerdas da crina do arco.

Decerto que esses pontos funcionam para o instrumentista tal qual a paleta funciona para o pintor, ou seja, possui várias cores e gradações de cor para executar seu trabalho.

Examinemos então as 3 variantes:

A (1) velocidade do golpe de arco, isto é, o quanto de tamanho de arco será usado entre o talão e o arco para tocar a nota. Ex: uma semínima a 60 M.M pode ser tocada com todo ou simplesmente com metade ou um quarto do arco. A (2) pressão exercida contra as cordas terá relação direta com as gradações dinâmicas, pois essa pressão tem muito mais relação com o peso do que com a pressão. Isso difere os que usam o peso do braço contra a corda, ou os que utilizam, de forma em pé, o instrumento pesando contra o arco. O (3) ponto de contato, onde o arco será tocado, preferencialmente entre o espelho e o cavalete, entre 5 centímetros antes do final do espelho do instrumento e vai até antes madeira do cavalete. Costumeiramente é a indicação de sul tasto e sul ponticelo: o primeiro quer dizer perto do espelho; e o último, perto ao cavalete.

Esses três fatores são interdependentes e a mudança de qualquer deles refletirá ainda que de forma mínima nos outros. Assim, sobre o assunto o professor Galamian ${ }^{87}$ ensina:

\footnotetext{
${ }^{87}$ GALAMIAN, Ivan. Principles of Violin Playing \& Teaching - second edition.
} 
$O$ aumento de pressão com constante ponto de contato requer 0 aumento de velocidade do arco; a diminuir a pressão requer diminuir a velocidade do arco.

Aumentar a pressão com constante velocidade do arco requer que $o$ ponto de contato seja movido em direção ao cavalete.

Diminuir a pressão com constante velocidade do arco requer que $o$ ponto de contato seja movido em direção do espelho.

Maior velocidade de arco com aumento da pressão requer que $o$ ponto de contato seja movido em direção do espelho.

Pouca velocidade de arco com constante pressão requer que o ponto de contato seja movido para o cavalete.

A prática interpretativa está profundamente relacionada a estilo, período e caráter apenas para citar alguns. Basta imaginar que executar Mozart é diferente de executar Beethoven e este será diferente de Bach e assim por diante. Nesse ponto o arco é fundamental, pois é responsável pela pronúncia e pela articulação das notas bem como responsável por timbre e volume. Somando-se aos golpes de arco; Detaché, Legato, Martelé, Staccato, Spiccato e Ricochet, acrescidos das variantes entre pontos de contato demonstrados por Galamian, há uma gama sem fim de possibilidades.

Essas situações são tão particulares que mudam de intérprete para intérprete por conta de escola, método e proficiência no instrumento. Diante da variedade de articulações do arco em volta da sonoridade, acreditamos que a melhor maneira de identificar essas categorias de articulações, relacionadas a período e estilo musical, é a proposta por Jeff Bradetich ${ }^{88}$, que adota um sistema muito interessante em que atribui as diversas passagens do repertório orquestral do contrabaixo com o uso de vogais e consoantes.

\section{Situação musical hipotética no 1:}

Ao cantar ou solfejar o "trio" da passagem de orquestra da $5^{a}$ Sinfonia de Beethoven, se usarmos as sílabas: pah, pah, pah ou tah, tah ou bahm, como se imitássemos essa articulação no instrumento, o resultado será o mais próximo do usual nessa obra.

\footnotetext{
${ }^{88}$ BRADETICH, Jeff. Double Bass - The Ultimate Chalenge. 2009, p. 108.
} 


\section{Situação hipotética no 2}

Neste exemplo temos a abertura da música Vocalise de Rachmaninov, com as sílabas: Lah-ah-ah, e da mesma forma ao imitarmos essa articulação no instrumento, o resultado será o mais próximo do usual nessa obra.

\section{Situação hipotética no 3}

Neste exemplo o excerto da obra de Stravinsky - Pulcinella, na qual há um dueto entre contrabaixo e trombone, a articulação correta será: Tah-Tah em articulação curta, Tahn-tahn em articulação média; e Tahm-tham usando uma articulação mais longa. É óbvio que outras consoantes e vogais são possíveis na aplicação desse princípio e dependerá das necessidades da música em questão.

\section{Mão esquerda dedilhados e posturas}

Trataremos agora de forma mais aprofundada as questões relacionadas com a mão esquerda e os dedilhados. Temos novamente uma nova problemática: Qual é a melhor postura para mão esquerda? Qual é a escolha para o melhor dedilhado para a execução musical? Qual o melhor sistema de posição atende de forma otimizada as questões musicais?

Pensamos que após o estudo sistemático sobre os assuntos da mão esquerda, essas perguntas serão mais esclarecidas e, assim, vamos a elas.

Existe uma padronização em anatomia para os movimentos do braço. Esses movimentos são decorrentes das movimentações do úmero sobre a escápula. Como não há exceção, temos algumas maneiras de conduzir os movimentos do braço dependendo da posição postural adotada pelo contrabaixista. Diferentemente dos instrumentos de corda, tais como violino e viola e até mesmo o violocello, não há necessidade de movimentos de muita amplitude. Já no contrabaixo necessitamos de vários ângulos e posições diferentes, em relação ao braço do instrumento, e de forma geral isso será determinado pela forma ou pela escola adotada pelo músico.

Examinemos, então, as três posturas distintas do braço do músico em relação ao braço do instrumento, que é a região onde se apoia o polegar, por exemplo, 1/2 posição do método Simandl. A segunda na região da curva do braço e próxima à caixa de ressonância do instrumento - $\mathrm{V}$ posição do sistema Simandl. E por último na região do harmônico da primeira oitava - aproximadamente entre a $V$ e VII 
posição do sistema Simandl, que também é denominada como área do capotasto, pela possibilidade do uso do polegar nessa região.

Para Gary Karr que toca o contrabaixo de forma vertical orienta que o cotovelo da mão esquerda devera fica na mesma altura da mão esquerda quando pressiona a corda (fig.64). Aliás, muito interessante ele usar essa metodologia em virtude das mudanças de posições, isto é, ele defende que se o cotovelo estiver em altura mais baixa que a mão esquerda, ele terá de fazer mais movimentos, prejudicando assim a execução musical. Por que mais movimentos? Basta pensar que, se o cotovelo do executante estiver mais baixo que as mãos, não região da $\mathrm{V}$ posição do sistema Simandl e a nota seguinte for uma oitava acima, o músico terá de levantar o cotovelo e realizar o movimento para atingir a próxima oitava. A melhor forma a ser adotada seria, então, deixar o cotovelo alinhado à mão esquerda e com apenas um movimento atingir a próxima nota em questão.

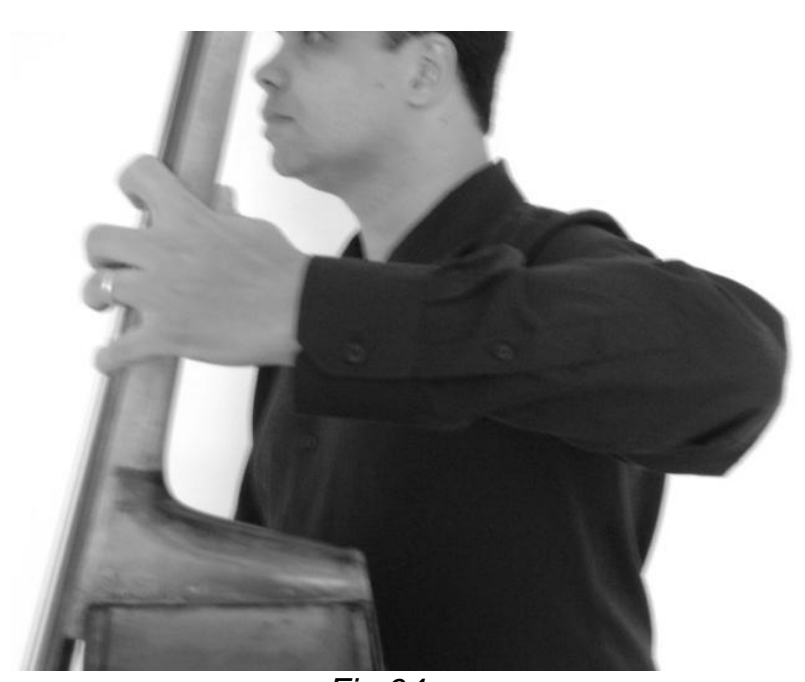

Fig.64

Mas entendemos também que o uso do cotovelo alto possa ser descartado quando assumimos a posição postural sentada (fig.65). O ângulo do braço justifica isso. Se, por ventura, o músico utiliza o instrumento com intenção violoncelística, poderá ser descartada a posição do cotovelo, e a resposta é de simples visualização. Se o instrumento fica muito próximo ao corpo não ocorrerá o que acontece na posição postural em pé. 


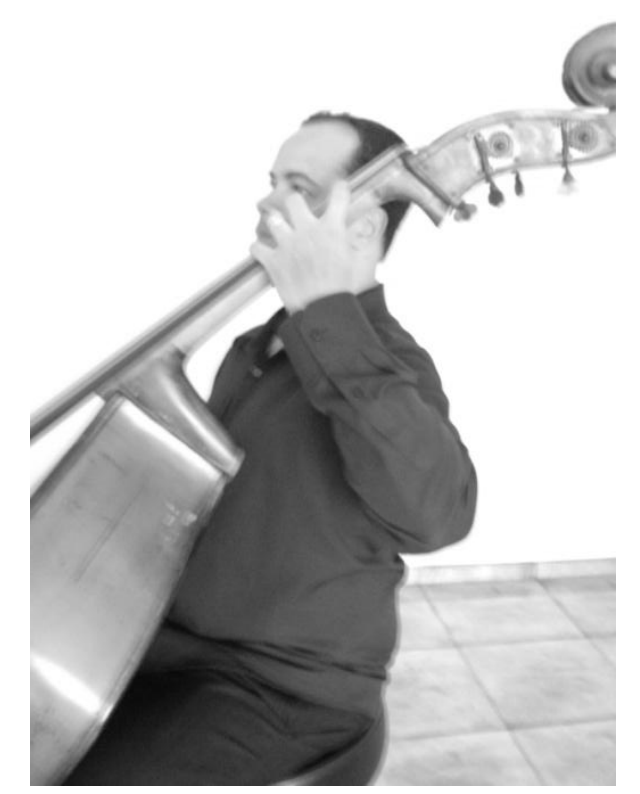

Fig.65

Dissemos das movimentações do úmero sobre a escápula e, de forma conjunta com o ombro esquerdo, é realizado um movimento vertical com esse sistema inteiro de forma simultânea. Não concordamos com essa maneira. Há limitação nesse movimento, e a razão é o fato de muitos músculos estarem envolvidos em apenas uma tarefa sem necessidade. Além disso, inviabiliza de forma considerável a transição para outros sistemas de posição como a extensão dos dedos, sistema Franck e pivô.

A nossa predileção é usada por alguns violonistas: o cotovelo fica levemente parado é há rotação em torno do eixo dele. Apenas com o movimento do antebraço da $1 / 2$ posição a VII com facilidade. E usar o antebraço como pivô, o que é possível em ambas as posições posturais, sentado ou em pé.

Também está relacionada o antebraço o ângulo da parte dorsal da mão esquerda. Quando a corda $G$ é tocada, a mão assume postura dorsal com o antebraço em menos de 180 graus. Desse modo, quando a corda $D$ é dedilhada ou digitada, a mão assume mais postura dorsal com o antebraço, ligeiramente maior do que na corda $\mathrm{G}$, aproximadamente 180 graus. De modo contrário, quando tocamos a corda A, assumirá a posição de flexão palmar com pouco mais de 180 graus e, assim, será ainda mais flexionada, quando tocada a nota $F$ na corda $E$, por exemplo. 
$\mathrm{Na}$ região do capotasto, onde é frequentemente usado o polegar da mão esquerda, o braço na maioria das vezes agirá de forma pronada e falaremos mais sobre essa região, quando tratarmos de dedilhado ou digitação.

\section{Sistemas de posição}

Para qualquer músico que não tenha conhecimento sobre os instrumentos de orquestra nos pergunta como é possível tocar as notas corretas pelo fato de não possuir trastes ou marcações tal qual o violão, contrabaixo elétrico ou guitarra. A resposta é que cada metodologia, ou como muitos preferem denominar como escola, adota princípios técnicos particulares, quando se trata da execução da mão esquerda. Esses sistemas existem primariamente para facilitar a localização das notas.

Simandl e Billé são os mais utilizados para o estágio inicial do aprendizado no contrabaixo acústico. Tais sistemas adotam o mesmo princípio, em que o músico aprende a tocar até três notas por corda em posição.

Meia posição é a primeira região aprendida, a única diferença é que, embora utilizem nomenclaturas similares, os métodos usam de forma diferente o segundo e terceiro dedos. Simandl aperta a nota A na corda G, com o dedo médio. Billé utiliza o dedo anular, em vez do médio. Em cada mudança ascendente de meio tom será dado um novo nome à posição: $1^{\mathfrak{a}}, 2^{\underline{a}}, 3^{\underline{a}}$ e assim sucessivamente. Na região médio aguda do instrumento, os autores utilizam: polegar, indicador, médio e anular.

Em verdade, muitos outros métodos posteriores a esses, usam o mesmo princípio de dedilhado ou digitação como costumamos dizer. Streicher, Montag Lajos e muitos outros adotam-nos em seus métodos, e a principal diferença é a experiência pessoal ao facilitar os dedilhados, seja na orquestra ou como docente.

Pensamos que esses sistemas são os mais utilizados e confortáveis para a execução do instrumento em qualquer registro, tanto nos graves ou nos agudos, quando se trata de passagens técnicas ou líricas. Porém, pelo fato de somente serem tocadas três notas por posição, com exceção do auxílio da corda solta, em passagens rápidas, fatalmente ficaram ineficientes por conta de repetitivas mudanças de posições. 


\section{Pivô, Quatro dedos e Extensão}

Pivô - essa técnica, apesar de ser utilizado também por outros instrumentos como o violoncelo, violino e viola, no contrabaixo é atribuída a François Rabath ${ }^{89}$. Tem esse nome pois funciona como um pivô - mão gira ou rotaciona sobre o polegar. O ganho técnico desse sistema, em comparação ao Simandl, é tornar possível tocar até dois tons em relação ao dedilhado e segue o mesmo princípio: indicador, médio e mínimo para os graves; e, na região médio aguda: polegar, indicador, médio e anelar.

\section{Quatro dedos}

Este método reduz o número de mudanças de posições. É também chamado de Franke System ${ }^{90}$. Alguns usam o termo "extensão", pois cada dedo está separado por um semitom permitindo que, em posição, o músico toque intervalo de $1 \frac{1}{2}$ tom do dedo indicador ao anelar. Isso reduz as mudanças de posição e permite que passagens rápidas soem mais claras, articuladas, como também reduz o portamento que, às vezes, é ouvido durante as mudanças de posição.

Sobre extensões ou técnicas com quatro dedos selecionamos um comentário do violoncelista Pablo Casals ${ }^{91}$ :

Como regra geral eu prefiro evitar saltos (mudanças de posição). Prefiro extensões. Você estará em melhores condições quando toca em posições fixas, apenas salte (mude de posição) quando realmente precisar.

O mesmo sistema é usado por outros instrumentos como violão, guitarra ou baixo elétrico (fig.66 e 67), em que cada semitom é digitado um dedo. Por exemplo, as notas F,F\#,G e G\# são digitadas pelos dedos 1, 2, 3 e 4, ou seja, indicador, médio, anular e mínimo, respectivamente. Dessa maneira conseguimos, em apenas uma posição fixa, executar até dois tons por posição.

\footnotetext{
${ }^{89}$ RABATH, François. Contrabaixista, solista, compositor e autor dos livros Nouvelle technique de la contrebasse.

90 DREW, Lucas. “Comparative Double bass fingering systems”, International society of bassists, V/2 (Winter 1979),480-481.

${ }^{91}$ APPLEBAUM. "Pablo Casals”, The Way they play, 14 vols. (Neptune City, N.J: Paganiniana Publications, Inc, 1972), I, 277.
} 
Ao passo que, ao usar o sistema Simandl, na mesma região serão utilizados os dedos 1, 2 e 3, uma vez que nessa metodologia, na região média e grave do instrumento, são usados os dedos 1, 2 e 4. Assim, por posição, teremos o prejuízo de meio tom com a possibilidade de tocar apenas F, F\# e G.

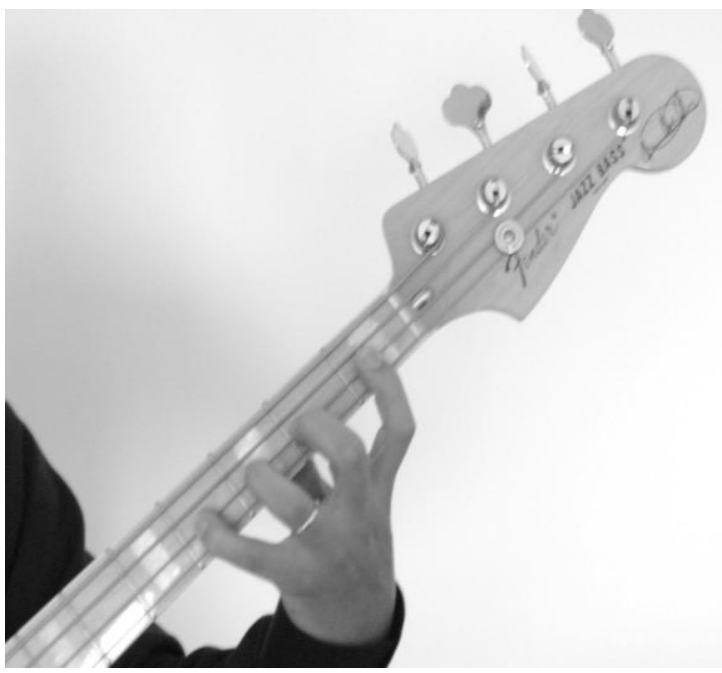

Fig.66.

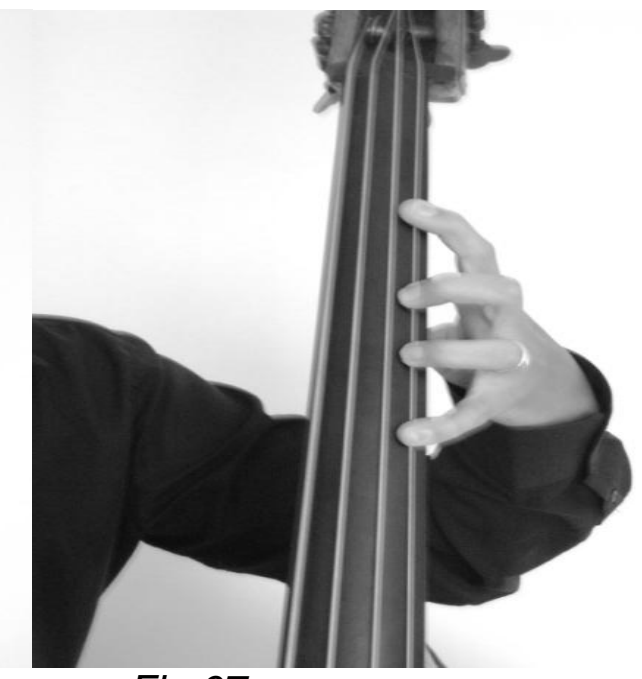

Fig.67.

É claro que esses exemplos demonstram a posição das notas somente em uma corda, mas os benefícios são estendidos às demais, quando se executam as posições. Acompanhamos a lição de Pablo Casals que prefere evitar saltos e usa posições fixas o máximo possível. Ao fazer isso, no contrabaixo, resolve-se e evitam-se diversos problemas técnicos como: articulações, legatos e afinação, sem contar o melhor: permite-se tocar uma escala maior ou menor em posição fixa. $\mathrm{O}$ que não é possível no sistema Simandl.

Aliás, o pioneiro da técnica de quatro dedos da mão esquerda foi Domenico Dragonetti, mencionado no livro a New History About Double Bass. Dragoneti usava os quatros dedos em posição fixa, tanto nas regiões graves quanto nas médias do instrumento, com o polegar na região do capotasto.

Nosso primeiro contato com o sistema de quatro dedos foi com o contrabaixista holandês, Hans Roelofsen ${ }^{92}$, nos idos de 1995, quando ele foi professor no Festival de Música de Brasília.

\footnotetext{
92 Hans Roelofsen foi o primeiro músico a receber o prestigiado prêmio da música holandesa em 1981 e é internacionalmente considerado um dos mais experientes contrabaixista de sua geração. Roelofsen é primeiro contrabaixista da Orquestra Filarmônica da Holanda e professor no Conservatório de Rotterdam.
} 
Entusiasta no uso do sistema de quatro dedos, aconselha pensar exatamente com se estivesse tocando contrabaixo elétrico digitando um dedo por traste.

Estamos convencidos de que a técnica com quatro dedos é o sistema mais adequado para os dias atuais na execução desse instrumento, e que, a longo prazo, o sistema Simandl entrará em desuso ou até mesmo desaparecerá. Essa tendência já é perceptível, nos Estados Unidos, a técnica é ensinada em coexistência com o sistema tradicional Simandl, por exemplo, na American School of Double Bass ${ }^{93}$ e na Universidade do Estado de Illinois. Na Alemanha, o americano Michael Wolf já o ensina há muitos anos na Universidade das Artes de Berlim.

O sistema de quatro dedos possui algumas nomenclaturas distintas, mas significam o mesmo. É chamado de open hand, extensão e técnica de quatro dedos. Entendemos também que há equívoco na nomenclatura, pois em nossa óptica só haverá extensão, se o músico utilizar o sistema tradicional, Simandl ou Bille, e em alguns momentos utilizar a técnica de quatro dedos.

Isso se dá por uma simples razão: para estender o dedo pressupõem-se as notas E, F e F\# na corda Re com os dedos 1, 2 e 4. Se há necessidade de tocar a nota G\# na corda Sol, sem a mudança de posição, ocorrerá a extensão. Assim, como demonstrado, é errônea a utilização de extensão para quem toca habitualmente com a técnica de quatros dedos, pela simples razão de nenhum dedo se "extender" a outra posição.

Uma das razões de esse sistema não ser muito utilizado é a forma errônea com a qual é empregado. Thomas Gale ${ }^{94}$ acredita que a técnica de quatro dedos é mal interpretada. Muitos instrumentistas mantêm os quatro dedos pressionados na corda (em bloco), sem empregar a ação de rotação do antebraço. Essa rotação do antebraço para as falanges dos dedos - parecida com o movimento do vibrato impedirá que braço e dedos fiquem rígidos. Pensando dessa maneira os músculos flexores - responsáveis pela flexão dos dedos - não agirão de forma conjunta e sim apenas sobre o dedo desejado.

\footnotetext{
${ }^{93}$ American Scholl of Double Bass, é uma escola Americana de Contrabaixo Acústico idealizada pelo Dr. Mark Morton, localizada no Texas na cidade de Lubbock.

${ }^{94}$ Thomas B. Gale é mestre em música pela Universidade Northwestern e um Bacharel em Ciência pela West Chester University. Estudou com Carl Torello da Orquestra de Filadélfia e Fashbender Rudolph da Sinfônica de Chicago.. Mr. Gale é um membro do corpo docente da American Scholl of Double Bass.
} 
Desse modo, basta deixar o peso natural do braço sobre o dedo ou dedos desejados; evitando, assim, a tensão desnecessária. Note-se que o apertar das cordas é executado de forma conjunta: músculos flexores e rotação do antebraço.

Apesar de nossa predileção sobre o sistema de quatro dedos, alguns tópicos negativos desse sistema devem ser ressaltados. A altura das cordas do contrabaixo, em relação ao espelho, não deve ser muito alta, pois pode gerar certo desconforto. Thomas Gale exemplifica que a altura das cordas não deve ultrapassar entre $3.5 \mathrm{e}$ $4.6 \mathrm{~mm}$. Aliás, cordas muitos altas, podem fazer que o contrabaixo acústico soe com mais intensidade, mas perderá o refinamento do vibrato, por exemplo. O músico fatalmente terá de empregar mais força física para apertar as cordas contra o espelho e a consequência será um vibrato tenso e sem fluidez, por causa da tensão exagerada provocada no braço e mão esquerda.

Outra observação a respeito da técnica de quatro dedos é que, em certos casos, há dificuldade em aplicá-la. Em contrabaixos muito grandes, ou seja, instrumentos que tenham comprimento de corda entre a pestana e o cavalete do instrumento superior a $108 \mathrm{~cm}$, encontrará o instrumentista dificuldades no uso da técnica de quatro dedos. No caso de um instrumento 4/4 que, segundo Henry A. Strobel ${ }^{95}$, mede $110 \mathrm{~cm}$ será improvável que a abertura dos dedos alcance meio tom de um dedo para o outro, nas regiões graves. Por exemplo, corda E notas F, F\#, Ge G\#, dedos 1, 2, 3 e 4. Nesse caso a melhor saída é usar o sistema Simandl ou Billé: dedos $1,1,2$ e 4 ou 1, 2, 4 e 4 .

Outra indicação para instrumento grande como o 4/4 é o uso da técnica de quatro dedos a partir do C\# da corda Sol; nessa região, o tamanho das posições é menor e, desse modo, será possível o uso da técnica.

\section{Extensão}

Para nós a extensão só ocorre, quando o dedo tenta alcançar outra nota além da posição em que se encontra. O sistema de digitação é conhecido também como "extensão", "técnica de quatro dedos" ou "Frank system" tendo aparecido em métodos e livros de contrabaixo acústico nos Estados Unidos desde 1886. ${ }^{96}$

\footnotetext{
${ }^{95}$ STROBEL, Henry A. Useful Measurements for Vionin Makers, p. 17.

${ }^{96}$ Gale, Thomas B. Technical Foudation Studies for Double Bass, vol I.
} 
A terminologia do sistema de extensão nos parece mais apropriado quando aplicado de forma conjunta ou híbrida com outros sistemas de posição. Isso ocorre, quando se usa o sistema misto: Simandl ou Billé com a técnica de quatro dedos.

Esse método é chamado, na American School of Double Bass, de Triangulation of Fingering Systems. É um triunvirato de sistemas de posições que inclui Simadl, técnica de quatro dedos e posições do polegar no capotasto.

Quando ocorre o uso concomitante dos sistemas ocorrerá a extensão. Basta imaginar a transição de um para o outro e ocorrerão movimentos da mão esquerda como expansão e contração. Expansão, quando a posição da mão estiver no sistema Simandl, com os dedos 1, 2 e 4, podendo expandir ou estender para a técnica de quatro dedos, com os dedos 1, 2, 3 e 4. Em sentido contrário ocorrerá a contração.

\section{Outros sistemas de digitação de mão esquerda}

Digitação ou dedilhado são soluções lógicas ou particulares que o instrumentista utiliza para otimizar a Arte. A seguir discorreremos sobre mais estilos e formas de digitação; lírica e técnica.

Em passagens cantábile a intenção é fazer o instrumento soar de forma mais próxima ao estilo vocal. Gary Karr foi o primeiro contrabaixista de que temos notícia que utilizou essa técnica, a qual consiste em usar os dedos mais fortes da mão esquerda, no caso o indicador e o médio. Em sua gravação ${ }^{97}$ da peça musical, Cisne do Carnaval dos Animais de Saint Saens, Gary Karr toca a peça inteira com o dedo médio da mão esquerda.

A postura lírica da mão consiste em aproximar todos os dedos da mão esquerda, ou seja, juntar os dedos dando suporte e sustentação ao dedo que aperta a corda. (fig.68)

\footnotetext{
${ }^{97}$ Karr, Gary. BASSically Karr Video.
} 


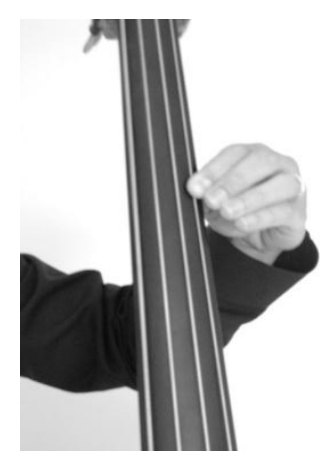

Fig.68.

Da mesma forma é possível utilizar a digitação lírica para todos os dedos. (fig. 69, 70, 71, 72, 73 e 74)

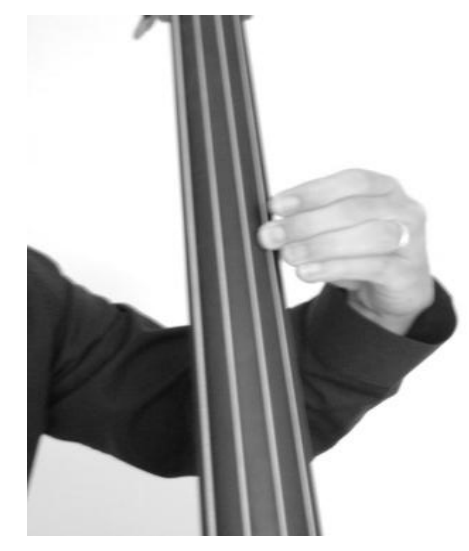

Fig. 69

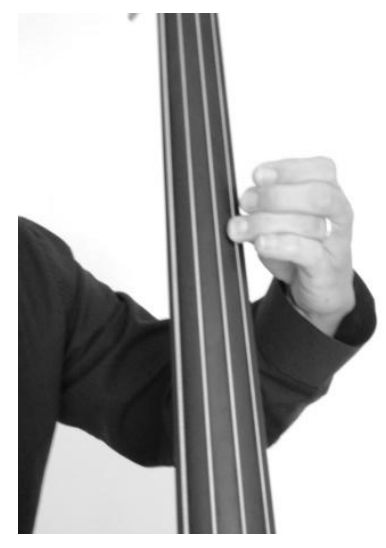

Fig.70

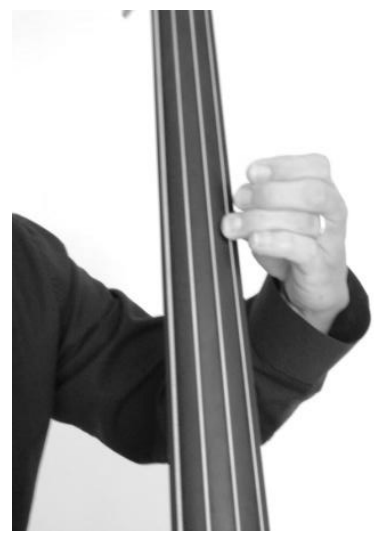

Fig.71

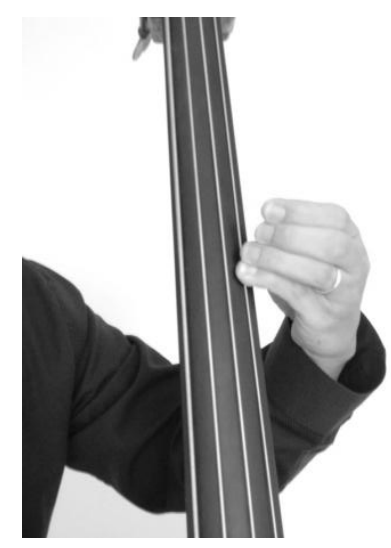

Fig. 72

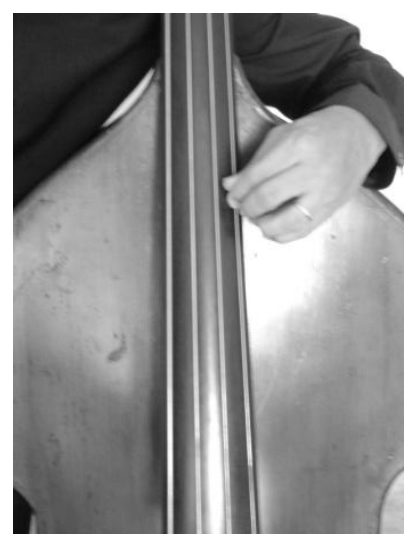

Fig.73

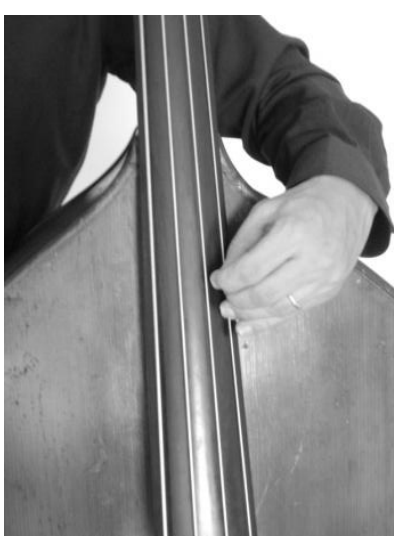

Fig. 74

Em contraste com o dedilhado lírico, teremos as passagens rápidas em que a digitação utilizada será a técnica. Ao usar esse estilo, o contrabaixista deverá evitar o uso de cordas soltas, optando assim por posições em bloco. 
Nesse tipo de digitação é possível tocar escalas maiores ou menores em apenas uma posição e são utilizadas freqüentemente em passagens rápidas. FIG

\section{Capotasto}

$\mathrm{Na}$ segunda parte do Metodo per Contrabasso de Giovanni Bottesini ${ }^{98}$, revisado e adaptado por Ítalo Caimmi ${ }^{99}$, para contrabaixo de quatro cordas, menciona que a primeira oitava da corda Sol é a região do capotasto.

Capotasto é a primeira região em que é utilizado o polegar da mão esquerda para digitar a nota. Os dedos, utilizados nessa região, são: polegar, indicador, médio e anular. Esses dedos são os mais comuns, porém há outros músicos que também utilizam o dedo mínimo (fig. 75), como é o caso dos contrabaixistas holandês Hans Roelfsen e do russo Rodion Azarkin.

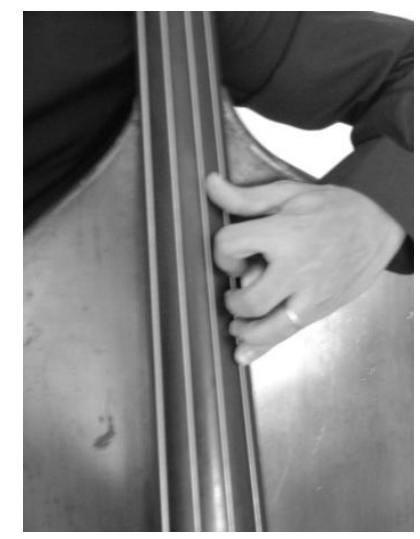

Fig. 75.

Uma interessante metodologia, na região do capotasto, foi desenvolvida pelo contrabaixista italiano Francesco Petracchi, na obra Simplified Higher Technique ${ }^{100}$, que é uma grande contribuição técnica para o contrabaixo.

Petracchi ensina que existem três posições básicas do polegar em relação ao capotasto. Cromática, que compreende três semitons ou uma terça menor nas notas E, F, F\# e G na corda Sol, com os dedos polegar, indicador, médio e anular. Semicromática, que compreende a distância de um tom e dois semitons ou uma

\footnotetext{
98 BOTTESINI, Giovanni (1821-1889) compositor italiano romântico, maestro e um virtuoso do contrabaixo.

${ }^{99}$ CAIMMI, Italo. Bottesini Metodo per Contrabasso, p. 60.

${ }^{100}$ PETRACCHI, Francesco. Simplified Higher Technique.
} 
terça maior nas notas $\mathrm{E}, \mathrm{F} \#, \mathrm{G}$ e G\# na corda Sol, com os dedos polegar, indicador, médio. Diatônica que compreende dois tons e um semi tom ou uma quarta justa.

Esse sistema desenvolvido por Petrachi é facilitador, pois é possível tal qual com a técnica de quatro dedos tocar quatros notas por posição, na região do capotasto.

\section{Grab ou Técnica Caranguejo}

Essa técnica, do contrabaixista francês François Rabath, permite obter mais segurança em notas sucessivas, assim como notas ligadas com o arco. Rabath diz que o importante é nunca retirar o dedo da corda, sem assegurar-se de que a nota sucessiva foi alcançada. Nas passagens ascendentes, o dedo correspondente à nota aguda deve arrastar a mão em direção ao cavalete e juntar os dedos até a intervenção do dedo seguinte. Em passagens descendentes, o dedo correspondente faz o movimento contrário, e a mão vai em direção à pestana, com o intuito de abrir os dedos até a próxima intervenção do dedo seguinte. ${ }^{101}$

A técnica do caranguejo é muito eficiente para passagens em legato tanto na forma ascendente ou descendente. De fato essa técnica nada mais é que contração e expansão da mão esquerda, com o diferencial de sempre deixar apertada a nota de destino até a digitação da próxima. O nome caranguejo refere-se à mudança dos dedos sobre a corda ser parecida ao movimento desse crustáceo.

\section{Estudo comparativo sobre mudança de posições}

Os sistemas de posição existem como facilitadores na execução do instrumento, ou seja, visam à mudança de posição para a próxima nota a ser tocada e consequente escalas e arpejos, cujos métodos e o estudo das escalas passamos a analisar.

Podemos dizer que uma das qualidades indispensáveis para a boa execução do instrumento é ter mudança de posições imperceptíveis, devido à distância das notas no instrumento.

${ }^{101}$ RABATH, François. Novelle Technique de La Contrebasse. 
Mark Morton dispõe em sua obra, Double Bass Tecnique Concepts and Ideas, tabela interessante sobre eficiência dos dedos para mudança de posições - a qual transcrevemos abaixo:

\begin{tabular}{|l|l|}
\hline Mudanças ascendentes & Mudanças descendentes \\
\hline 1 para o 4 & 4 para o 1 \\
\hline 1 para o 3, 2 para o 4 & 4 para o 2, 3 para o 1 \\
\hline 1 para o 2, 2 para o 3, 3 para o 4 & 4 para o 3, 3 para o 2, 2 para o 1 \\
\hline 1 para o 1, 2 para o 2, 3 para o 3, 4 para o 4 & 4 para o 4, 3 para o 3, 2 para o 2, 1 para o 1 \\
\hline 2 para o 1, 3 para o 2, 4 para o 3 & 3 para o 4, 3 para o 2, 2 para o 1 \\
\hline 3 para o 1, 4 para o 2 & 2 para o 4, 1 para o 3 \\
\hline 4 para o 1 & 1 para o 4 \\
\hline
\end{tabular}

Os dedos indicador, médio, anelar e mínimo são representados pelos números 1, 2, 3 e 4 respectivamente. Esses dedilhados ou digitações aparecem em ordem descendente de eficiência. $O$ primeiro item da tabela representa a mais eficiente mudança de posição, e a última da tabela, de forma inversa, a menos eficiente. Todos os outros dedilhados ou digitações que aparecem na mesma lacuna da tabela oferecem a mesma eficiência em relação à mudança.

Ao observar alguns métodos de escalas será mais fácil interpretar o quadro sobre mudança de posições. Ludwig Streicher, professor da escola de Viena, em seu livro Toleiter um Akkordstudien - Scales and Chords Studies, utiliza a mesma concepção. Ao tocar a escala de Dó maior, neste método, em uma oitava, utiliza os dedos 2,0,1,2,0,1,2 e 4; de forma descendente 4,4,1,0,2,1,0 e 2; ou seja, utiliza a regra descendente 4 e 1 sendo mais eficiente a mudança de posição.

Outra proposta do estudo de escalas é de Joseph Prunner, contrabaixista e professor de músicos como Wolfgang Gutler e Yoan Goïlav, usa o mesmo princípio, em que as escalas em ordem ascendente possuem dedilhado; e de forma descendente; outro. Aliás, esse método não possui edição recente, mas na atualidade vem sendo bastante usado devido a sua sistemática. Nesse livro, as escalas são encaradas de forma progressiva, no formato de modos gregorianos, oitava por oitava, e esse diferencial não é encontrado em nenhum método de escala conhecido por nós. Nesse padrão de escalas, ocorre o mesmo procedimento: escala ascendente com um dedilhado; e descendente, com outro.

Da escola francesa de contrabaixo temos Jean-Marc Rollez, professor do Conservatório Superior de Paris, autor da coletânea em três volumes intitulada, 
Méthode de contrebasse - Le contrebassist virtuoso ${ }^{102}$. Sobre essa obra nos interessam apenas os volumes 2 e 3, porque o volume 1 trata de exercícios para resistência e força e, neste momento, nos ateremos apenas aos métodos de escalas.

Rollez tem abordagem bem interessante sobre as escalas. Em seu prefácio diz que a obra contém escalas com duas e três oitavas; evitando sempre que possível o uso das cordas soltas. Com isso afirma que o estudante, no uso de seus livros, adquire rapidamente agilidade, independência, força e destreza, todas qualidades indispensáveis para a mão esquerda. A digitação/dedilhado é bem interessante e peculiar, pois é variante do sistema Simandl e usa, na região grave do instrumento, os dedos 1, 2 e 4; na média aguda, polegar, 1,2 e 3; e na escala de duas oitavas ao tocar a escala. Diferentemente dos livros já citados, Rollez apresenta, além de dois dedilhados para cada escala maior ou menor, letras de A a $\mathrm{J}$ com fragmentos e padrões de escalas que forcem o aluno a adquirir conhecimento técnico em todas as cordas do instrumento. Essa coleção chamada de "o contrabaixista virtuoso" é indispensável para quaisquer contrabaixistas tanto amador quanto profissional.

Eugene Levison, russo-americano naturalizado, escreveu o mais recente livro técnico para escalas, The School of Agility. De forma geral, as escalas de duas ou três oitavas começam na região grave do instrumento e, quando ascendem para a parte aguda, é sempre usual tocar-se na corda Sol. O diferencial da técnica de Levison é abordar o instrumento utilizando os mesmos princípios usados pelo grande pedagogo do violino, Carl Flesh, que explora todas as partes do instrumento. Isto é, nesse método as escalas são tocadas com várias combinações em todas as cordas. Tais combinações chegam a dezesseis por escala maior e menor, e apenas uma para os arpejos.

No que tange à ordem de eficiência dos dedos, possui um diferencial. Cada posição, ou melhor, em cada corda há possibilidade de tocar três notas. Quase poderíamos chamar a técnica de "Levison de quatro dedos". A diferença é que a de quatro dedos é possível tocar um tom inteiro entre os dedos 2 e 4 e 1 e 3 ; nesta "nunca" é usado o intervalo de um tom com os dedos 2 e 4 , mas é permitido tocar um tom com os dedos 1 e 3 .

${ }^{102}$ ROLLEZ, Jean-Marc. Le contrabassist virtuose, vol. 1, 2 e 3 - Editour Gerárd Billaudot. 
Em nossa opinião o livro é revolucionário, porém necessita de atualização. Apesar de a primeira edição ser relativamente nova e datada de 2002, o ponto negativo a nosso ver é sobre o prefácio e a utilização. $O$ autor expõe que o uso e os princípios adotados são de Carl Flesh ${ }^{103}$, o que - do nosso ponto de vista - é problemático, porque esses princípios, como as variações de arco e direcionamento do estudo contidos na escola Flesh, não são contemplados no livro. Fora esse ponto, trata-se de brilhante obra sobre variações de dedilhados, e o ponto negativo apontado pode ser suprido com o uso concomitante dos livros de violino: Scale System e The Art of Violin Playing, ambos de Carl Flesh.

Ainda sobre Flesh, existe edição compilada e transcrita do livro de violino Scale System para contrabaix ${ }^{104}$, de Gerd Reinke ${ }^{105}$, cuja notação musical é idêntica ao método de violino adaptada para o contrabaixo. Muito funcional, apresenta escalas de uma oitava, arpejos maiores e menores, diminutos e aumentados, escalas em terça como escala cromática. As escalas são apresentadas sempre em uma oitava na região grave, região média e aguda e, por último, escalas com três oitavas completas. Uma das diferenças marcantes é que, tal qual o método de violino, este livro traz escalas com notas duplas em terças e quintas, o que não é usual na maioria dos métodos já mencionados por nós. Outro diferencial é que Reinke dispõe ao final do livro, além das variações contidas no tradicional sistema Flesch, um suplemento com variações de arco para estudo. Há instruções no prefácio, feitas pelo autor, para a prática de mínimo trinta minutos do estudo de escalas com a prevalência da tonalidade da música ou peça que o aluno/músico estiver trabalhando.

Sem dúvida é um acréscimo importantíssimo para a nossa literatura. No entanto fazemos menção aos dedilhados/digitação contidos no livro. O autor, em sua larga experiência, deixa a cargo do executante escolher qual a melhor forma da execução da digitação e dispõe apenas algumas básicas. Para os alunos avançados e músicos profissionais, que já possuem conhecimento sobre o assunto, o método é mais indicado.

\footnotetext{
${ }^{103}$ Carl Flesh (1873-1944) foi violinista e professor.

${ }^{104}$ FLESH, Carl. Scale System. Arranged for Double Bass by Gerd Reinke

105 Gerd Reinke estudou música na Academia Hamburgo. Trabalhou na Ópera de Berlim, Academia de Música de Berlim e Bayreuther Festspiele até 1997.Desde 1998, vive no Cairo,e em Berlim como solista independente de contrabaixo.
} 
François Rabath ${ }^{106}$ contribuiu muito na área pedagógica do contrabaixo com a técnica contida em sua obra Nouvelle Technique de La Contrebasse, em três volumes. No método Rabbath, diferentemente de Simandl que possui várias posições como meia, primeira, segunda e assim por diante, o braço inteiro é dividido em apenas seis posições, definidas pela localização dos harmônicos naturais sobre as cordas. No mais, os livros são bem organizados e seu conteúdo fotográfico, textual e filosófico é claro, conciso e lógico. De forma gradual, desde os primeiros passos do instrumento, nos primeiros volumes, é ótima fonte de pesquisa.

Atribui-se a Rabath a técnica do pivô, com a rotação do antebraço com o polegar, em posição atrás do braço do instrumento como também da técnica "caranguejo" em que a mão se movimenta ao espelho do contrabaixo, como se fosse um caranguejo andando de forma lateral.

As escalas em três oitavas completas estão no terceiro volume de seu método. Muito abrangente é são sugeridos vários dedilhados/digitações e escalas em terças. As notas duplas são mais completas que os demais livros; terças, quartas, quintas e oitavas. Em fato o manual pode ser usado por todos os instrumentistas seja em que nível de expertise se encontre.

Por último, adentraremos a análise dos livros de escalas para contrabaixo do Dr. Prof. Mark Morton. Sempre com a abordagem de pesquisador que the é peculiar possui três livros de escalas intitulados: Primer Scale \& Arpeggio Fingerings for Double Bass, Miraculous Scale Fingering for Double Bass e Miraculous Arpeggio Fingerings for the Double Bass.

No primeiro, dirigido a iniciantes, inclui dedilhados/ digitações básicas para escalas: natural, menor, menor harmônica, menor melódica, escalas cromáticas e arpejos maiores, menores e dominantes em todas as tonalidades. Nesse volume não há nenhuma contribuição expressiva a nossa literatura sendo mera compilação, ainda que organizada, do sistema Simandl.

No livro Miraculous Scale Fingering for Double Bass, Morton realmente se supera produzindo metodologia bastante completa. Afirmamos ser o livro mais completo de escalas do qual temos notícias, pois em suas mais de 200 páginas (isso somente de escalas) inclui digitação/dedilhados para as mais diversas escalas em

${ }^{106}$ François Rabbath (nascido em 1931, em Aleppo, na Síria) contrabaixista francês, solista e compositor. 
uma, duas e três oitavas como: maior, menor, menor natural, harmônica menor, melódica menor, cromática, tons inteiros, diminuta, pentatônica maior e menor, em todos os tons. Para cada há dois tipos de dedilhados, rápido ou lento. Rápido para passagens tal qual o nome; e lento para passagens cantábile que utiliza os dedos mais fortes e resistentes, de forma lógica em relação à digitação, para o que Morton criou a expressão "money note". A tradução literal do termo é "nota da grana" e ele se refere a notas tocadas com a mão esquerda, com extrema força e qualidade, para as quais usa os dedos indicador e médio.

A diversidade de seu livro de arpejos segue a mesma concepção, com quase 140 páginas. Sem sombra de dúvidas é um dos trabalhos mais completos sobre o tema. Nossa única oposição é sobre as variações de golpes de arcos e exercícios rítmicos. Desse modo, é necessário que se estude com outro livro de forma suplementar para preencher essa lacuna. Nossa sugestão é o uso do livro de violino parte II do Sistema de Escalas de Ivan Galamian, que trata de vários padrões sobre ritmo e arco.

\section{Conclusão sobre escalas e arpejos}

A prática de escalas é comum e deve ser habitual em todos os instrumentos musicais. No contrabaixo não poderia ser diferente, e a grande importância de seu estudo se dá pelo fato de servir como veículo para o desenvolvimento das habilidades técnicas do instrumento e refletem em ambas as mãos. Escalas estabelecem afinação, e sua prática com o arco melhora a qualidade de emissão sonora e gradações dinâmicas.

Em nossa exposição sobre escalas citamos a literatura mais usada na atualidade. Expomos representantes das mais diversas nacionalidades e dos mais diversos sistemas dedilhados/digitações. Chegamos à conclusão de que a diversidade é ótima ferramenta a auxiliar o músico profissional, aluno ou amador. Todos os sistemas ilustrados por nós são dignos de respeito, afinal são trabalhos de renomados músicos e professores que dedicaram suas carreiras em prol do contrabaixo acústico.

Apesar de nossa opinião diversa acerca de alguns pontos sobre aspectos metodológicos, cremos que todos os métodos citados são imprescindíveis na literatura do instrumento. $O$ dedilhado/digitação da escala é reflexo do sistema de 
posição utilizado. É claro que a pergunta será: Qual o livro a ser estudado? A resposta deverá ser: todos devem ser estudados. Dizer que o aluno ou profissional praticará todos esses livros de forma simultânea é um grande exagero. Nossa sugestão é que tenha um sistema "base", ou seja, vamos tomar, por exemplo, que o aluno esteja familiarizado com o sistema Simandl. Ele pode estudar de forma complementar o livro de escalas de Eugene Levinson. Ressaltemos que o estudo de um livro não é apenas ler as notas e sim passar algum tempo com a metodologia, não podemos esquecer que esses livros são resultado de uma carreira musical, e temos em mente que seu estudo por alguns meses deve ser suficiente para familiarizar-se com outro. O mesmo para os que acreditam não mudar de técnica, porque tocam as mesmas escalas há muitos anos, um novo livro de escala exercitará a mente, posto que não é algo automatizado como de costume - o músico terá que exercitar seu lado cognitivo é em um ótimo exercício intelectual.

\section{Vibrato}

Expressão em italiano que é uma oscilação de altura, durante a execução da nota ou das notas, no caso de duplas. $O$ vibrato ${ }^{107}$ é uma ferramenta de expressão na qual há oscilação da nota provocada por movimentos da mão esquerda. A execução dessa ferramenta possui várias formas e versões diferentes sobre sua eficácia. O que nos interessa são os movimentos da mão esquerda em relação a essa oscilação da nota. De fato o vibrato é ferramenta muito pessoal e cada músico em sua execução apresenta pequenas diferenças entre: tipo, extensão, alteração da nota e timbre.

Segundo Mark Morton existem três dimensões básicas do vibrato, listadas por relevância em instrumentos de corda: afinação, intensidade (volume) e timbre. Essas dimensões possuem subdivisões de tamanho e extensão.

\footnotetext{
107 Vibrato (it.) Uma oscilaçao de altura (mais raramente, de intensidade) em uma única nota durante a execução. Empregado, sobretudo, por instrumentistas de cordas e cantores, o vibrato já era conhecido no sec. XVI. Na execução de cordas é produzido vibrando-se o dedo que comprime a corda. Uma técnica mais antiga consistia em vibrar o dedo, enquanto um segundo roçava a corda com delicadeza. $O$ vibrato era considerado basicamente como ornamento, apesar de alguns teóricos (em especial Geminiani) defenderem seu uso quase que constante, o que veio a ocorrer apenas no séc. XIX, pela necessidade de uma sonoridade maior e mais rica. Circunstâncias semelhantes possibilitam o vibrato na execução de instrumentos de sopro (conhecido já em 1707) e no canto. GROOVE, Dicionário de Música, Edição Concisa. p. 90.
} 
Deformação e rotação são os dois tipos de movimentos usados para o uso do vibrato. Deformação ocorre quando o músico apenas movimenta a falange distal para frente e para trás, o que oscila a nota. Para compreender esse movimento, basta visualizar a ponta dos dedos limpando uma superfície com dois centímetros de tamanho com o dedo médio ou indicador, o nome deformação é autoexplicativo e se dá pela falange ficar imóvel. Pelo movimento ela deforma-se e volta a sua posição natural. Na Rotação, o antebraço age de forma giratória transmitindo o movimento para as falanges distais, semelhante à técnica do pivô, por nós já explicada. Com uma bola tênis é possível descrever o movimento, basta segurá-la contra o tórax, e fazer movimentos para frente e para trás rotacionando o antebraço.

Para Michael Wolf ${ }^{108}$, o vibrato por deformação não é eficiente. Deslizar os dedos sobre a corda produz grande efeito de oscilação da nota sendo esse método muito usado por contrabaixistas que tocam jazz, mas o resultado desse tipo de vibrato é geralmente não funcional para o uso com arco. A desvantagem ressaltada por Wolf é que, devido a grande força despendida para apertar a corda com a mão esquerda, podem ocorrer problemas com a afinação. Nesse sentido, para ele só a técnica da rotação oferecerá mais precisão nos movimentos. Haverá mais amplitude e controle para a as oscilações por conta do movimento do pivô.

Jeff Bradetich afirma que o vibrato não é realizado com a rotação do dedo, mão ou pulso e não pode ser relacionado com os vibratos usados em viola ou violino. Esse tipo de movimento de rotação trabalha de modo contrário à natureza do contrabaixo. Ele explica que o movimento do vibrato é similar ao de agitar uma lata de refrigerante e ensina a realizar esse exercício agitando a lata rente a terceira posição do contrabaixo (nota B corda Sol).

Outra questão relativa ao vibrato é a direção. O vibrado é mensurado em hertz, que é a unidade de frequência equivalente a um ciclo por segundo. Cada ciclo é o impulso da mão para cima e para baixo (sentido agudo ou grave do instrumento) não importando o método utilizado de deformação ou rotação. Irrelevante também se o impulso começa para frente ou para trás, isto é, para frente em direção do cavale e para trás na direção da voluta do instrumento.

${ }^{108}$ WOLF, Michael. Principles of Double Bass Technique. 
Estudo muito interessante, feito por Louis Cheslock ${ }^{109}$, indica a proporção em relação ao vibrato em instrumentos como violino, viola em sua pesquisa de 1932 . Os vibratos desses instrumentos eram entre seis e sete hertz (ciclos por segundo). Essas oscilações são muito próximas da voz humana, que é de sete hertz.

Além de ser ferramenta de expressão, não se pode esquecer que o vibrato deve ser usado sob contextos estilísticos. Certos estilos usam-no em demasia, como é o caso do período romântico; outros menos, como o barroco. Para o violinista Leopol Auer, muitas vezes citado neste trabalho, o vibrato não pode ser usado sob alguns pretextos. Primeiro, no caso de tentar camuflar má afinação; segundo, porque deve ser usado com parcimônia, pois é um tempero que, ao ser colocado demais na comida, pode estragá-la.

O contrabaixo é um instrumento de frequências graves, de tal modo que as cordas, principalmente na região grave do instrumento, vibram com menos intensidade. Essa diminuição também se dá em relação à média de hertz, quando o vibrato é usado. É claro que a quantidade de ciclos, tamanho ou intensidade variará para cada situação musical, porém 4.8 hertz é uma boa média e produz um vibrato de forma razoável. Traduzindo em termos musicais: duas colcheias são idênticas a um movimento da mão ou dedos para frente e para trás. No instrumento, ao usar o ritmo com duas colcheias, em velocidade de $144 \mathrm{MM}$, tem a semínima como unidade de tempo, chega-se a um vibrato de 4.8 hertz. De outra forma, não há limite para a para o quão rápido poderá vibrar o instrumentista, mas a máxima velocidade possível girará em torno de 6.8 hertz ou semínima a 195 MM nos mesmos modos já explicados. De toda forma, o vibrato com mais velocidade de forma a ser musicalmente aceitável gira em torno de 5.8 hertz ou semínima a 174 .

O tamanho do vibrato é ligado à amplitude do movimento; os curtos querem dizer vibrato pequeno; os longos, grande. Costumeiramente, quando se vibra em notas graves, a velocidade é menor e consequentemente mais lenta, sendo possível executar o movimento com mais amplitude. Em outros instrumentos, como no violino, é possível vibrar até entre um intervalo de semitom, isso acontece pelo tamanho do instrumento cujo intervalo é bem próximo.

\footnotetext{
${ }^{109}$ CHESLOCK, Louis. "Introductory study in violin vibrato," Research Studies in Music, Ed. Otto Ortoman (Baltimore: Department of Research of the Conservatory of Music, Peabody Conservatory of Music, 1931), p.60-70.
} 
Desse modo a oscilação do vibrato ocasiona variações na altura da nota. Cantores, por exemplo, podem vibrar entre o intervalo de uma terça menor, ou seja, a nota do ponto de partida do vibrato ocorre entre a nota de partida e a seguinte. Aconselhável é não vibrar mais que um quarto de tom e, no contrabaixo, isso não é um problema. Devido à larga distância entre os intervalos para conseguir alcançar um quarto de tom, é bem provável que o instrumentista tenha de usar recursos como glissar ou rotacionar os dedos de uma forma que alcance o intervalo de um quarto de tom.

Em relação aos tipos de vibrato nossa opinião é que devemos estudar todos, tanto a rotação como a deformação e suas variantes, porque entendemos que existem dois tipos: o que funciona e o que não. Ao menos o aluno ou profissional deve conhecê-los, pois o melhor vibrato é aquele que incorpora de forma sistêmica a dedo, mão e braço em diferentes amplitudes, velocidades e graus variados visando sempre à criação do contexto musical desejado. As articulações devem ser sempre flexíveis com vários graus de intensidade e de relaxamento.

Para o contrabaixista, escritor e professor Barry Green ${ }^{110}$, em seu livro, Advanced Techniques of Double Bass Playing, braço, antebraço, pulso e mão são responsáveis pela oscilação do vibrato. Em verdade, utiliza deformação e rotação, porém com ressalvas - no registro grave do instrumento em especial nas cordas $\mathrm{Mi}$ e La, cordas IV e III respectivamente aplica-se a rotação com uma grande amplitude de movimento, ou seja, vibrato lento com movimentos largos. Ainda, exemplifica o movimento como tentar acertar um objeto ou lápis imaginário com o dedo mínimo (apertando com o dedo indicador a nota $\mathrm{G}$ na corda Mi). O dedo mínimo tentaria martelar (movimento similar aos martelos do piano contra a corda) o objeto na nota A da corda Mi. Pensamos que um exemplo melhor para ilustrar o movimento seria a execução do trinado, que é a repetição rápida e alternada de duas notas musicais vizinhas. Tocar o trinado com a rotação do braço é a maneira ideal para as notas graves das cordas Mi e La (da nota E corda solta a nota D da corda A). Por outro lado, o uso da deformação somente é usado nas regiões medias e agudas do instrumento, que no caso em questão, nas cordas Re e Sol.

\footnotetext{
${ }^{110}$ GREEN, Barry, Contrabaixista, americano autor de inúmeras obras tais como The Inner Game of Music, The Mastery of Music, Ten Pathways to True Artistry.
} 
Neste caso não é usada a rotação de pulso, braço ou antebraço e sim uma pequena oscilação provocada pela falange distal.

Ao apertar a corda contra o espelho estaremos fazendo algum tipo de pressão, seja lá com os tendões flexores ou de maneira pronada com a mão esquerda. A tensão é prejudicial a qualquer tarefa diária por mais simples que seja; ainda mais no contrabaixo porque força empregada para sua execução será maior ao comparar com violinistas, violoncelistas e violistas.

A solução achada por nós mais apropriada para quem possui um vibrato ineficiente é o que diz o ex-professor da violoncelista Jacqueline du Pré, William Pleeth, autor do já mencionado livro Cello e adequamos ao nosso caso a correção ou até mesmo a reabilitação do movimento do vibrato.

Adequamos o nosso instrumento à lição de William Pleeth. Contrabaixistas que desenvolveram um vibrato inadequado devem conseguir ou tentar uma maneira de voltar e retreinar a mão esquerda, para isso o músico deverá voltar aos estágios iniciais do aprendizado. Isto é, deverá parar de usar o vibrato por algum tempo. Esse tempo poderá ser de alguns dias ou semanas. Essa sugestão é eficiente, pois desassocia a mão esquerda da produção de som (muitos até de forma inconsciente apertam demais a mão esquerda) cujo responsável primário é o arco.

Em suma, o vibrato é mais uma ferramenta necessária para construção da arte musical. Em princípio deve ser praticado de forma racional, medem-se as oscilações com o auxílio do metrônomo, na marca entre 60 e 80 MM. Usam-se colcheias, tercinas, quatro, cinco e seis semicolcheias por tempo. Nossa sugestão é que seu uso e prática sejam parcimoniosos e somente use as figuras rítmicas do estudo para aquisição dos movimentos na execução. Por outro lado, ao executar o vibrato, quando se executa uma música, devem ser esquecidas essas figuras rítmicas e sua execução deverá ser pertinente com o estilo e período da obra. E nunca é demasiado ressaltar que a prática na forma de estudos, escalas e arpejos do mesmo modo o estudo da peça musical em questão sem vibrato algum. Depois de aprender a música sem qualquer vibrato, poderá o músico desassociar a mão direita e focar sua atenção para esta significante ferramenta que é o vibrato. 


\section{PRÁTICA}

\section{As bases psicológicas do aprendizado}

A prática deve estar ligada intrinsecamente a nossa higidez. Fala-se sobre otimizar o tempo de forma organizacional. A prática, horas a fio, sob o contrabaixo poderá desencadear processo inflamatório, por isso devemos direcionar o estudo e conceituá-lo com um processo criativo de aperfeiçoamento das habilidades musicais com o domínio da obra musical em questão, sempre visando à performance. A prática racional proporcionará mais resultado e despenderá menos tempo. Assim, não serão mais necessárias tantas horas e poupa-se corpo e evitando lesões como LER ou DORT.

Ao dominar e entender algumas bases psicológicas do aprendizado poderemos seguramente aplicá-las. Segundo a concepção de Vygotsky, se a aprendizagem está em função não só da comunicação, mas também do nível de desenvolvimento alcançado, adquire então relevo especial - além da análise do processo de comunicação - análise do modo como o sujeito constrói os conceitos comunicados e, portanto, a análise qualitativa das "estratégias", dos erros, do processo de generalização. Trata-se de compreender como funcionam esses mecanismos mentais que permitem a construção dos conceitos e que se modificam em função do desenvolvimento. ${ }^{111}$

Dos ensinamentos de Vygotsky iremos nos concentrar nas "estratégias" para a otimização de nossa prática. É claro que cada indivíduo tem o seu próprio método de aprendizado. Há músicos que são mais auditivos (isso é muito comum em músicos populares que não alfabetizados musicalmente e tocam seus instrumento por repetição, ouvem e reproduzem); outros são visuais, cujo aprendizado melhora ao ver e observar, isso é comum na relação aluno e professor, pois o estudante acaba - mesmo que de forma inconsciente - absorvendo a personalidade musical do mestre; há ainda o cinestésico, cujo aprendizado é feito por memória muscular. Este última muito comum, quando o músico apenas sabe quais dedos apertar, ou seja, a música não é interiorizada de forma intelectual.

${ }^{111}$ VYGOSTSKY, 1991, p. 2 
Colocando ideias de forma prática, começaremos criando um ambiente propício para a boa prática. Primeiramente dispomos uma lista de acessórios essenciais para o seu local de estudos:

1. Cadeira ou banco (ajustada a sua forma de tocar).

2. Estante de partitura (ajustada preferencialmente à altura dos olhos, de modo que não haja necessidade de inclinar a cabeça, para frente ou para trás).

3. Um caderno de anotaçõe, lápis e borracha (o caderno para as anotações sobre metas e progresso; lápis e borracha também para fazer anotações no material que esteja em trabalho).

4. Metrônomo eletrônico e afinador (damos preferência a metrônomos eletrônicos, pois os mecânicos com o tempo ficam imprecisos).

5. Relógio com timer (o músico pode em sua estratégia de prática monitorar o tempo dedicado a cada item em estudo).

6. Espelho (ótima ferramenta de ajuda para eliminar maus hábitos posturais).

7. Gravador de som e filmadora (com essas ferramentas é possível virar assistir-se, o que é muito útil para o aprimoramento técnico/musical).

8. Garrafa de água ou suco (o cérebro e as articulações trabalham melhor quando estão hidratados).

9. Ambiente claro, calmo e com o menor barulho ou ruído possível.

A proposta é transformar seu escritório ou seu quarto de estudo, escola e universidade em um espaço criativo, a lista acima é apenas exemplificativa e cabe ao músico, aluno ou professor adicionar as demais ferramentas que poderão ajudálo em sua prática.

Deste ponto em diante traremos vários planos e estratégias para o estudo do instrumento. Administrar o tempo de forma a ser eficiente é o desafio da vida moderna, cuja locomoção em grandes cidades consome muito tempo. Assim, um plano de organização mostra-se muito necessário. Complementando o item 3 de nossa lista de acessórios essenciais para o estudo, abaixo uma tabela organizacional: 


\begin{tabular}{|c|c|}
\hline $\begin{array}{l}\text { AQUECIMENTOS } \\
\text { 1. Escalas e arpejos } \\
\text { 2. Notas longas } \\
\text { 3. Variações Rítmicas }\end{array}$ & $\begin{array}{l}\text { OBJETIVOS ESPECIFICOS } \\
\text { 1. Elementos básicos para produção musical } \\
\text { 2. Controle e resistência do arco para } \\
\text { passagens cantábile. } \\
\text { 3. Aplicados a escala e arpejos. }\end{array}$ \\
\hline $\begin{array}{l}\text { ESTUDOS E EXERCICIOS } \\
\begin{array}{l}\text { 1. Leitura à primeira vista } \\
\text { 2. Métodos } \\
\text { 3. Estudos Técnicos }\end{array}\end{array}$ & $\begin{array}{l}\text { OBJETIVOS ESPECIFICOS } \\
\text { 1. Proficiência e habilidade de leitura musical. } \\
\text { 2. Familiaridade com diversas escolas técnicas. } \\
\text { 3. Aperfeiçoamento a habilidades especifica no } \\
\text { instrumento. (constantemente exigida } \\
\text { dependendo do nível em que se encontra o } \\
\text { músico). }\end{array}$ \\
\hline $\begin{array}{l}\text { REPERTÓRIO } \\
\begin{array}{l}\text { 1. Peças e solos } \\
\text { 2. Repertório novo (novas músicas a } \\
\text { serem estudas). }\end{array} \\
\text { 3. Repertório antigo (músicas que já } \\
\text { fazem parte do repertório). }\end{array}$ & $\begin{array}{l}\text { OBJETIVOS ESPECIFICOS } \\
\text { 1. Estudo da literatura do instrumento. } \\
\text { 2. Peça ou concerto a ser aprendido ou } \\
\text { memorizado. } \\
\text { 3. Exercício do repertório já aprendido. }\end{array}$ \\
\hline $\begin{array}{l}\text { PASSAGENS DE ORQUESTRA } \\
\text { 1. Passagens novas (novas músicas a } \\
\text { serem estudadas). } \\
\text { 2. Passagens antigas (músicas que já } \\
\text { fazem parte do repertório). } \\
\text { 3. Simulados para concurso em } \\
\text { orquestra sinfônica }\end{array}$ & $\begin{array}{l}\text { OBJETIVOS ESPECIFICOS } \\
\begin{array}{l}\text { 1. Passagem de orquestra a ser aprendida ou } \\
\text { memorizada. }\end{array} \\
\begin{array}{l}\text { 2. Exercício de passagens orquestrais já } \\
\text { aprendidas. }\end{array}\end{array}$ \\
\hline $\begin{array}{l}\text { JAZZ } \\
\text { 1. Improvisação } \\
\text { 2. Estudar com softwares e play backs } \\
\text { 3. Estudo de estilos }\end{array}$ & $\begin{array}{l}\text { OBJETIVOS ESPECífICOS } \\
\text { 1. Estudo da improvisação usando como } \\
\text { suplemento alguma obra sobre o tema. } \\
\text { 2. Simular a performance. } \\
\text { 3. Estudar os estímulos musicais pertinentes ao } \\
\text { jazz, como: New Orleans, Swing, Bebop, Hard } \\
\text { bop, Cool, West Coast, Free, Fusion, Latin } \\
\text { Jazz e Third Stream. }\end{array}$ \\
\hline \multicolumn{2}{|c|}{$\begin{array}{c}\text { OUTROS } \\
\text { 1. Teoria e percepção } \\
\text { 2. Transcrições de peças } \\
\text { ção de livros teóricos relacionados com o instrumento e gravações sobre o } \\
\text { contrabaixo e outros instrumentos. } \\
\text { 4. Assistir a concertos das mais variáveis atrações. }\end{array}$} \\
\hline
\end{tabular}

O quadro acima é apenas exemplificativo, mas tenta gerenciar a maior parte das necessidades musicais relacionadas ao estudo. 
É claro que a tabela faz referência ao aspirante ou músico profissional e podem ser adaptados aos mais diversos níveis de dificuldade.

Voltemos ao tempo a ser despendido. O conteúdo é realmente bem extenso, mas é possível de forma eficiente a otimização. Sob o título Pratice Time Ratios and $\operatorname{Order}^{112}$ que, em nossa tradução, significaria: relações da prática entre tempo e ordem. O autor percentua uma hora de prática, em assuntos necessários no estudo do contrabaixo, e depois expande o tempo conforme o aluno ou músico profissional disponha dele. E nesse sentido sua prática começará da seguinte forma:

1. $10 \%$ Escalas e arpejos.

2. $10 \%$ Exercícios Técnicos ou Estudos.

3. $10 \%$ Jazz.

4. $20 \%$ Passagens de Orquestra.

5. $40 \%$ Repertório Novo.

6. $10 \%$ Repertório Antigo.

Desnecessário mencionar que o músico deverá fazer alongamentos, antes e ao final da prática. O percentual acima só faz sentido com o seu complemento que é uma tabela de minutos a ser aplicada. Se o músico dispuser de uma hora de prática, proporcionalmente será o seguinte:

1. 6 minutos

2. 6 minutos

3. 6 minutos

4. 12 minutos

5. 24 minutos

6. 6 minutos

$\mathrm{Na}$ exposição desses argumentos, em 2001, em sala de aula na Universidade de Columbus - Ohio, questionei ao professor Mark Morton sobre o tempo ser muito curto, para o que ele me mostrou a seguinte progressão:

Duas horas:

1. 12 minutos

2. 12 minutos

3. 12 minutos

4. 24 minutos

5. 48 minutos

6. 12 minutos
Três horas:

1. 18 minutos

2. 18 minutos

3. 18 minutos

4. 36 minutos

5. Uma hora e 12 minutos

6. 18 minutos

${ }^{112}$ MORTON, Mark Alison. (autor já mencionado) 
Quatro horas:

1. 24 minutos

2. 24 minutos

3. 24 minutos

4. 48 minutos

5. Uma hora e 36 minutos

6. 24 minutos
Cinco horas:

1. 30 minutos

2. 30 minutos

3. 30 minutos

4. Uma hora

5. Duas horas

6. 30 minutos

Seis horas:

1. 36 minutos

2. 36 minutos

3. 36 minutos

4. Uma hora e 12 minutos

5. Duas horas e 24 minutos

6. 36 minutos

Essa progressão matemática é de grande valia e seu resultado funcional é muito bom e não temos nenhuma ressalva sobre essa metodologia. Uma única consideração foi sobre outra pergunta feita por nós, à época dessa exposição ao professor. Achamos que determinado tempo possa ser muito pouco para a resolução de problemas técnicos e perguntamos qual seria sua opinião. Respondeunos de forma bastante fraternal: o aluno deve ter em mente que possui $X$ tempo para resolver o problema, ou seja, no exemplo 1. Escalas e arpejos tendo com base apenas 6 minutos disponível, o aluno deverá resolver seu problema técnico nesse tempo.

Outra linha de pensamento com alguns pontos parecidos com as nossas tabelas de estratégias é do educador musical Gerald Klickstei ${ }^{113}$, ao definir sua maneira de pensar sobre o estudo musical o qual adota em seu plano prático e denomina: The Five Practices Zones, que traduzimos e adaptamos para: Cinco Áreas de Estudo.

Material novo, material em desenvolvimento, material para performance, Técnica e Musicalidade. Esses cinco itens completam-se, pois talvez encontremos os mesmos elementos musicais em tópicos distintos. O material novo pode ser qualificado como música nova a ser aprendida ou memorizada, o material em desenvolvimento pode ser exemplificado como uma obra muito complexa, necessitando de um trabalho a longo prazo.

\footnotetext{
${ }^{113}$ Gerald Klickstein, professor de música da Universidade da Carolina do Norte, autor do livro The Musician's Way.
} 
A prática nessa área é muito importante, principalmente aos estudantes em transição para a vida profissional, pois a qualquer momento podem ser exigidos a tocar o repertório para admissão, em comparação a vários autores executando a mesma peça, a análise harmônica ou qualquer aprofundamento intelectual sobre a obra em estudo. O planejamento dessas cinco áreas podem ser organizados da seguinte maneira:

\section{MATERIAL NOVO}

Dividir a obra musical em estudo em seções. Essa divisão se chama prática $A B C^{114}$, que muito parece com a confecção de uma colcha de retalhos, na qual são juntados pequenos quadrados (retalhos) formando quadrados maiores. Primeiramente nomeie uma seção ou parte da música com a letra A (lembre-se que essa letra nada tem haver com análise harmônica ou melodia) que pode ser 4, 8, ou 16 dezesseis compassos. Assim nomeie sucessivamente quantas letras forem necessárias e cada letra pode representar pequenas frases ou passagens musicais. Explicamos: Primeiro pratique somente a primeira passagem $A$, depois somente $B$ deste mesmo modo $C$ e $D$. Feito isso, pratique $A B$ conjuntamente, depois $B C$ e $C D$ e DE. Da mesma forma junte $A B C, B C D, B C D, C D E$ e finalmente todas as letras $A B C D E$.

Estabelecer um plano interpretativo. A música como forma de expressão é metódica e seu silogismo deve ser respeitado. O intérprete, ao executar determinada música, não deve apenas se preocupar com as notas, mas sim com toda estrutura da obra. Para isso, a análise harmônica e estética é imperativa. É muito comum entre os jovens músicos apenas se preocuparem com a afinação e notas e se esquecerem da importância da análise. Um exemplo muito próximo disso é do professor e contrabaixista Gary Karr que menciona no encarte de sua gravação do Concerto de Dvorak para violoncelo transcrito para contrabaixo, que de tanto analisar a obra em questão, teve momentos que achava que a composição tinha sido sua. Em suma, em um plano interpretativo a vida do compositor com seu trabalho obrigatoriamente devem ser estudados.

Estudar lentamente. Este tópico como todos os outros é muito importante e podemos compará-lo com a fábula da tartaruga e o coelho. Ao estudar de forma lenta o instrumentista permite que se cérebro tenha mais tempo de processar a informação e dominar a tarefa a ser feita. Quando tocamos uma passagem rápida, na maioria das vezes já possuímos ou adquirimos certas habilidades de contextos musicais semelhantes, ou seja, na é aperfeiçoado. Quando executamos uma passagem de um Movimento Alegro em uma velocidade reduzida como 60 M.M, muitas imperfeições podem ser percebidas como afinação e ritmo. Ou seja, na prática lenta iremos agir como a tartaruga: "devagar e sempre chegaremos ao fim da corrida". Em sentido contrário ao de estudar lentamente está a opinião de François Rabath, em seu vídeo educacional The art of the bow, no qual diz que é contrário à prática lenta e associa ao andar de um bebê. Rabath diz que, quando uma criança começa a andar, ela não começa andar com gestos lentos ela "simplesmente anda". Não concordamos com a opinião dele, pois a prática lenta é uma das principais ferramentas para aquisição de habilidades técnicas/musicais. E nas palavras de Streicher: "O que você não é capaz de tocar lento, não será capaz de tocar rápido". ${ }^{115}$

\footnotetext{
${ }^{114}$ FISCHER, Simon. 250 step-by-step practices methods by violin.

${ }^{115}$ STREICHER, Ludwig. Tonleiter um Akkordstudien.
} 


\section{MATERIAL EM DESENVOLVIMENTO}

Refinamento da Interpretação. Interpretar possui uma estreita relação com a composição. De fato, colaboramos com o compositor e recriamos sua obra que é o processo inverso da composição. Fora o aprimoramento literário que deve ser constante sobre o material em estudo uma boa forma de adquirir boas ideias sobre interpretação é comparar gravações de diversos intérpretes. O ato de ouvir outras "recriações" da obra em estudo já é propriamente um estudo. E por muitas vezes encontramos em várias gravações que nos norteiam a nossa própria versão. Explicamos: ao ouvirmos duas gravações da mesma música, podemos gostar de pontos interpretativos distintos de ambas. Gostamos do andamento (tempo) de uma, mas das frases musicais de outra. Assim, poderemos ter uma "terceira via" interpretativa, utilizando os dois elementos das duas gravações em nossa interpretação.

Aumento do metrônomo. Este item deve ser tratado de forma conjunta com a prática lenta. O aumento do metrônomo de forma gradual tendo como ponto de partida o tempo lento é um caminho fácil e efetivo para aquisição técnica. O material em desenvolvimento pode ser uma obra extensa e deve ser trabalha em longo prazo para um bom resultado.

Comece a tocar em um tempo lento e use as seguintes marcas abaixo, aumentando-as de forma gradual ${ }^{116}$ :

Colcheia $=80,84,88,92,96$

Semínima $=60,63,66,69,72$

Minima $=60,63,66,69,72$

Simon Ficher usa um truque muito interessante, a partir do tempo lento que o máximo em alguns metrônomos chega a 30 M.M ao completar a peça inteira, frase, ou passagem ele aumente 10 marcas do metrônomo. Novamente repete o trecho, diminuindo 5 marcas do metrônomo. E assim sucessivamente até chegar ao andamento desejado da obra.

Gary Karr, também adota a prática em aumentar o metrônomo em forma gradual, porém aumentado somente 5 marcas por dia. Deste modo, em alguns dias o contrabaixista irá alcançar o andamento desejado sem nenhuma dificuldade.

${ }^{116}$ FISCHER, Simon 250 step-by-step pratices methods by violin, pag. 2. 


\section{MATERIAL PARA PERFORMACE}

Este item como todos os outros deve ser comparado a uma casa ou apartamento que de tempos em tempos necessita de manutenção. $\mathbf{O}$ material para performance é a música requisitada em nossa vida musical. Se o contrabaixista for profissional da música popular, ele deve sempre exercitar as músicas que frequentemente toca, se músico de orquestra; as principais passagens orquestrais normalmente exigidas do repertório sinfônico, se solista; as principais peças ou concertos dos quais sempre toca. O que muitos músicos, alunos ou profissionais esquecem-se ao estudar uma música é que dali por diante ela começa fazer parte de sua vida e podemos compará-la como uma planta que precisa sempre ser regada para continuar viva.

Memorização. Antes de relacionar a memória a tema proposto faz-se necessário ressaltar algumas informações sob nossa capacidade de reter informações. Podemos dizer que a mente humana está equipada, basicamente, com dois tipos de memória:

Memória de curto prazo ou imediata grava informações por alguns segundos e memória de longo prazo ou remota é um registro duradouro de informações. Em fato o que nos interessa é como atingir este registro duradouro. O hipocampo (pequena estrutura bipartida localizada no centro do cérebro) é que autoriza o registro duradouro das informações. Assim, pesquisas indicam que duas situações influenciam o hipocampo:

Interesse: A informação atingirá a memória de longo prazo se tiver significado emocional, ou melhor, converterá a memória imediata em remota na proporção pelo interesse pela informação.

Repetição: A informação terá maior probabilidade de registro se guardar fazendo correlação com o que já sabemos, além da revisão da informação a ser revisada.

Em geral, a eficiência da memória humana é auxiliada pela estranha faculdade da mente humana - a capacidade de esquecer. É o paradoxo de não revisar informações. Ou seja, não revisar o material em fase de aprendizado ou não fazendo o mesmo com o material já existente, fatalmente iremos esquecer o já aprendido. Aliás, revisar as obras já estudadas é de muita importância para a manutenção; sobre 0 assunto o pesquisador Ebbing Haus ${ }^{117}$ que após anos de estudo concluiu:

- Em uma hora, esquecemos $56 \%$ do que é lido;

- Em nove horas esquecemos mais $8 \%$;

- Em dois dias esquecemos mais 6\%;

- Em um mês esquecemos mais 7\%;

Uma situação muito comum e comentada por alguns profissionais é a dificuldade de "fazer" ou tocar música de cor, ou seja, de memória. Se perguntarmos a esse grupo de pessoas: Você estuda para melhorar sua memorização? A resposta será: Eu não tenho facilidade de memorizar músicas. Com essas assertivas, temos em mente que o aluno ou profissional tem dificuldades para memorizar a música pelo fato de não estudar esse tema de forma específica. A memorização faz parte do estudo também e deve ser dada a devida importância, tal qual o estudo de escalas, arpejos ou exercícios técnicos.

\footnotetext{
${ }^{117}$ Hermann Ebbinghaus (1850-1909) Filósofo e psicólogo alemão.
} 
A seguir alguns passos para a memorização sugeridos por nós:

1. Toque a passagem ou trecho musical lendo a partitura.

2. De forma simultânea toque e solfeje a passagem ou trecho lendo a partitura.

3. Usando a memória, simultaneamente toque e solfeje a passagem ou trecho musical.

4. Usando a memória, longe do instrumento, imaginando um contrabaixo imaginário (faça mímica, imitando tocar com os dedos e um arco imaginário) solfeje a passagem ou peça.

5. Mentalmente pense nos dedos a serem tocados conjuntamente com os ritmos a serem tocados.

6. De cor, com o uso do solfejo (com os acidentes) a passagem inteira.

7. Toque a passagem ou trecho da peça no piano ou outro instrumento. Ex. violão.

8. Toque a música de forma conjunta com o computador (midi). Atualmente há na internet de forma gratuita o repertório ${ }^{118}$ de contrabaixo para ser baixado e pode ser rodado em programas como o Finale o u Sibelius. Com este sistema que é chamado de playback, é a forma de estudo mais próxima que existe em relação à performace, pois simula a orquestra ou piano que são comumente o acompanhamento.

9. Toque a passagem inteira, mencionando todas as dinâmicas e os acentos quando ocorrer.

10. Toque a peça, trecho ou passagem de memória.

\section{TÉCNICA}

Escalas e arpejos podem ser encarados como elementos de "pura" técnica. Sobre as principais maneiras estilos de escalas e arpejos já nos pronunciamos em momento especifico, mas não deixamos de ressaltar sua importância. Pensamos que os estudos técnicos têm por finalidade facilitar a execução da musica. De tal modo, que os estudos técnicos e suas especificidades no instrumento devem ser realizados de forma conjunta conforme a necessidade. Em poucas palavras, nada adianta estudar oitavas em notas duplas, sendo que a musica em estudo não contempla estas notas. A técnica deve ser um facilitador.

Temos em mente que o estudo de livro de técnica de outros instrumentos pode ser bem útil na evolução técnica do instrumento com o é caso

${ }^{118} \mathrm{http}: / /$ www.wolfbass.com/ 


\section{MUSICALIDADE}

Qualidade musical e a tradução da palavra musicalidade. Para os músicos o termo vai além dessa definição. Para nós o termo exprime habilidade musical que engloba vários aspectos inerentes a ciência musical dos quais; leitura a primeira, vista, teoria musical, percepção, composição, improvisação, apreciação musical.

A leitura a primeira vista por sua vez é qualidade do músico em não precisar formar os sinais, como se analfabeto fosse para executar o trecho da música. A proficiência em ler musica deve ser considerada e exercitada devendo fazer parte da prática diária também. Nos anos 80 e 90 principalmente no Estado de São Paulo era utilizada como parte na avaliação no ingresso dos quadros da Ordem dos Músicos do Brasil e neste mesmo sentido aplicado nos testes de Orquestra como no Teatro Municipal de São Paulo. Atualmente a leitura de primeira vista em testes de admissão em orquestras foi suprimido, sendo comum a lista de trechos de orquestra predeterminados no respectivo exame.

Teoria Musical é a nomenclatura dada a qualquer sistema ou conjunto de sistemas destinado a analisar, classificar, compor, compreender e se comunicar musicalmente. Há uma deficiência sobre o assunto principalmente em escolas especializadas sobre o assunto. Em São Paulo, por exemplo, só avalizamos o curso da Escola Municipal de Musical. Porém, o curso é muito extenso, dura cerca de sete (anos) e a metodologia é antiga, mas em se tratando de instrumentos de cordas como é o caso do contrabaixo é uma boa referência. Temos em mente que alguns ramos da teoria musical devem ser sempre revisitados, pois ajudam maio compreensão do contexto musical e sua prática deve ser concomitante com o instrumento.

Percepção, talvez essa seja uma ferramenta tão importante quanto o instrumento musical. Ela é nosso tradutor e de certa forma os próprios olhos do musico que ao ouvir sons percebe sua altura, intensidade, timbre e coloratura. A percepção é relacionada com a memória e vê ser sempre exercitada não importando o nível em que se encontra o músico. Temos algumas sugestões para sua pratica que com os avanços tecnológicos sua prática também é possível fora da sala de aula. As aulas de percepção se traduzem com o professor executando algumas notas ou trecho musical e o aluno os transcreve para a linguagem musical escrita. Hoje, todavia, com o uso da informática a prática é possível das mais diversas formas. Softwares como: Trasncribe, Ear Master Pró, Band in a Box são bastante úteis para a prática perceptiva. O Transcribe diminui a velocidade da gravação em formatos em áudio, $\mathrm{mp} 3$ ou wave, mantendo sua tonalidade original permitindo que o musico possa transcrever a musica com maior facilidade. O Ear Master é um dos mais completos nessa categoria ajuda desenvolver habilidades auditivas e teoria musical, desde iniciantes até muito avançados. Nesse software é possível de forma gradual o aprendizado em identificar, transcrever intervalos, acordes, escalas, modos, ritmos e melodias. O Band in a Box por sua vez é mais direcionado a jazz e musica popular é em verdade um simulador que seu próprio nome já diz como uma banda dentro de uma caixa, no qual possui ferramentas para o reconhecimento de intervalos e acordes.

Composição e improvisação outro ramo da musica que deve ser exercitado de forma conjunta com o instrumento. Alguns músicos rejeitam estas praticas com o argumento em não terem vontade em tornarem-se compositores ou improvisadores. Nossa opinião é que mesmo com o valido argumento estes dois itens dever ser levados em consideração e inseridos na grade de estudo diária. $\mathrm{O}$ fato que compondo e improvisando o musico exercitará diversas áreas do cérebro, dentre elas a criatividade indispensável para a recriação musical.

Apreciação musical para nós não é somente a atividade do ouvinte, do público, que envolve a fruição estética do produto sonoro. Apreciação musical também poder ser voltada ao músico profissional ou estudante. É claro que a diferença talvez seja que o aluno ou profissional tenha como alvo; gravações e obras em que esteja trabalhando ou estudando. Temos em mente também a necessidade de não somente ouvir, mas fazê-lo de forma critica inclusive com o uso de fichários e resenhas que podem ser acompanhados ou não com a musica, juntamente com a análise estética e musical da obra em estudo. 
Adaptando os conceitos de Gerald Klickstein para o nosso repertório poderíamos montar um plano de prática nos seguintes moldes:

\begin{tabular}{|c|c|}
\hline $\begin{array}{lr}\text { Material novo } & \\
\text { Divida a musica em seções } & \text { Concerto B menor } \\
\text { Giovanni Botesini } & \\
\text { Estabelecer um plano técnico e intepretativo } & \text { Sonata Arpegione de } \\
\text { Schubert } & \\
\text { Pratica em tempos lentos } & \end{array}$ & $\begin{array}{c}\text { Tempo } \\
\text { gasto } \\
60 \mathrm{~min} .\end{array}$ \\
\hline $\begin{array}{l}\text { Material em desenvolvimento } \\
\text { Refinamento de interpretação; } \\
\text { Sebastian Bach } \\
\text { Aumento no andamento; } \\
\text { Memorização; }\end{array}$ & $40 \mathrm{~min}$. \\
\hline $\begin{array}{lr}\text { Material de performance } & \\
\text { Pratica em performance; } & \text { Concerto em E maior, Carl Ditters } \\
\text { von Dittersdorf, } 3 \text { movimentos } & \\
\text { Manutenção da memória; } & \text { Trechos de orquestra sinfonias } \\
\text { de Beethoven }-3^{\mathrm{a}}, 5^{\mathrm{a}} \text { e } 9^{\mathrm{a}} & \end{array}$ & $20 \mathrm{~min}$. \\
\hline $\begin{array}{ll}\text { Técnica } & \\
\text { Escalas; } & \text { Escalas e arpejos maiores e } \\
\text { menores com as mais diversas variações de arco e dedilhados. } \\
\text { Livros técnicos; } & \text { Petrachi, Gradus Parnassum, } \\
\text { Rabath devem ser levados em conta. } & \end{array}$ & $30 \mathrm{~min}$. \\
\hline $\begin{array}{lc}\text { Musicalidade } & \\
\text { Leitura à primeira vista; } & \text { Storch-Hrabe - } 57 \text { Studies } \\
\text { Volume 1 } & \\
\text { Composição e improvisac̃ão; } & \text { Componha melodias em } \\
\text { progressões harmônicas II-V-I } & \\
\begin{array}{l}\text { Percepção; } \\
\text { Estudo literário }\end{array} & \begin{array}{c}\text { Ear Master Pro } 5 \\
\text { Biografia sobre Dittersdorf }\end{array}\end{array}$ & \\
\hline
\end{tabular}

Essas estratégias são meramente exemplificativas e devem ser ajustadas de forma conjunta entre professor e aluno. Todavia o músico profissional não encontrará mais problemas para adaptá-las ao plano de estudo.

Para outros exemplos sobre a prática do instrumento não podemos deixar de mencionar Pablo Casals, do qual tinha o hábito de começar seus estudos diários tocando Bach para "santificar a casa"119. Aliás, há alguns anos, quando já nascia a vontade de escrever sobre os mais diversos tipos de prática no instrumento, tomei a liberdade de enviar e-mail ao famoso contrabaixista Gary Karr, perguntando sobre uma possível sugestão de prática de estudo, e ele prontamente respondeu:

${ }^{119}$ PLEETH, Willian, CELLO, pg. 10. 
“Querido Maurício,

Obrigado por sua pergunta. Eu gostaria de oferecer um pouco de mágica para a sua pratica, mas tenho que admitir que minha agenda prática não seja tão diferente da de qualquer um. Eu começo o dia com exercícios com as escalas (estas com base nos meus livros) e gasto cerca de meia hora concentrando-me numa perfeita afinação e um controle de arco bem relaxado. Então eu toco mais meia hora das suítes de Bach (cello suítes) por mais meia hora, também me concentrando em afinação e controle do arco. Depois disso trabalho novas peças e gasto a maior parte do meu tempo criando bons arcos e dedilhados, a fim de dar suporte artístico as minhas idéias e frases. Assim, se depois de algumas horas, eu ainda tenha energia, gosto de tocar peças que aprendi recentemente, do início ao finm. Eu sempre estudo perto da janela para que eu possa ficar relaxado olhando para a tranqüilidade da natureza. Eu nunca trabalho duro. Eu tenho uma regra que, se é um trabalho árduo, eu devo estar fazendo errado. Eu sempre tento praticar o instrumento de forma mais descontraída possível. Desta forma, tudo vem fácil." (Gari Karr 12018 de maio de 2003) (tradução nossa)

Como vimos, não existe um plano de prática absoluto, mas sim diversos relativos. É comum o aluno ou profissional só sentir-se em segurança para tocar em público o que já denominamos como performance, fazendo antes um verdadeiro ritual de escalas arpejos e estudos antes de executar o jogo que é tocar a música. Desse modo, outra sugestão à prática trazida por nós e por Galamian é mudar a ordem do estudo. Não está escrito em lugar algum que temos o dever de começar a prática com escalas. Podemos começar pela própria música ou deixar a técnica por último. O problema se dá em sempre fazer o mesmo ritual prático, porque o corpo e o psicológico do executante só se sentirão preparados após todas aquelas escalas, arpejos e exercícios técnicos que ele acha necessários.

Em suma, é claro que dependendo do estágio em que se encontra o músico variará a carga horária a ser estudada. Sobre isso, gostaríamos de transcrever recomendações gerais para o progresso musical conforme o nível em que o aluno

\footnotetext{
${ }^{120}$ Dear Maurício,

Thank you for your question. I wish that I could offer you some magic, but I have to admit that my practice schedule is not so different from anyone else. I start everyday with scale exercises (based on those in my books) and spend about a half hour concentrating on perfect intonation and relaxed bow control. Then I play some unaccompanied Bach suites for another half hour, also concentrating on intonation and bow control. After that I work on new pieces spending most of my time creating good bowings and fingerings in order to support my artistic ideas of phrasing. Then, if after a couple of hours, I still feel energetic, I like to play recently learned pieces from beginning to end. I always practice near a window so that I can be relaxed by looking at the tranquility of nature. I never work hard. I have a rule that if it is hard work, I must be doing it wrong. I always try to practice relaxed as possible. In this way, everything comes easier.

Thank you for writing.

Very basst wishes,

Gary Karr
} 
ou profissional se encontre. Estas recomendações são para a prática diária sem a pressão da performance ou concurso de orquestra pela frente e são sugeridas pelo professor Jeff Bradetich ${ }^{121}$ :

\begin{tabular}{|l|l|l|l|l|}
\hline Prática & Iniciante & Intermediário & $\begin{array}{l}\text { Estudante da } \\
\text { Graduação }\end{array}$ & $\begin{array}{l}\text { Músico } \\
\text { profissional }\end{array}$ \\
\hline Exercícios técnicos & $15 \%$ & $15 \%$ & $40 \%$ & $15 \%$ \\
\hline Solos & $70 \%$ & $60 \%$ & $25 \%$ & $50 \%$ \\
\hline Métodos e Estudos & $15 \%$ & $15 \%$ & $20 \%$ & $0 \%$ \\
\hline Trechos Orquestrais & $0 \%$ & $10 \%$ & $15 \%$ & $35 \%$ \\
\hline
\end{tabular}

A quantidade de horas também seguirá o esquema acima:

\begin{tabular}{|l|l|l|l|l|}
\hline Iniciante & Intermediário & $\begin{array}{l}\text { Estudante da } \\
\text { Graduação }\end{array}$ & Músico profissional \\
\hline 20 minutos & Uma a três horas & Quatro horas & $\begin{array}{l}\text { Três a quatro } \\
\text { horas }\end{array}$ \\
\hline
\end{tabular}

${ }^{121}$ BRADETICH, Jeff. DOUBLE BASS, The Ultimate Chalenge, p. 148. 


\section{PREPARANDO-SE PARA A PERFORMANCE}

\section{Medo de palco (Stage fright)}

Medo de palco ou ansiedade de performance é a ansiedade, medo ou persistente fobia, que pode ser despertada em um indivíduo pela obrigação de executar à frente de uma platéia. Embora existam literaturas diversas sobre regras de composição, compêndios sobre o instrumento a ansiedade de performance é um campo ainda quase inexplorável.

Algumas características da ansiedade de performance é que ela é diretamente se relacionada com o medo ${ }^{122}$. Esse medo é de não ser suficiente bom para a tarefa a ser realizada. Comumente ela aparece em audições admissionais para ingresso ao emprego, que em nosso caso é a Orquestra, ou em situações públicas como é o caso de recitais ou atuação como solista.

A ansiedade de palco afeta de forma a acelerar nossos batimentos cardíacos, com o aumento da excreção da epinefrina (que é um sinônimo da adrenalina) que em momentos de "stress", as suprarrenais secretam quantidades abundantes desse hormônio, que prepara o organismo para grandes esforços físicos, estimula o coração, eleva a tensão arterial, relaxa certos músculos e contrai outros. Provoca também mudanças na excreção de Noradrenalina, também chamada de Noraepinefrina, é uma das monoaminas que mais influenciam o humor, ansiedade, sono e alimentação junto com a Serotonina, Dopamina e Adrenalina. Podemos traduzir os efeitos sobre o músico que serão: confusão mental, sudorese, tremor muscular, constrição muscular, boca seca, náuseas e hiperventilação. ${ }^{123}$

Há diferença significativa entre medo e ansiedade. Medo é a reação ao perigo específico, enquanto ansiedade é "vaga" sem objetivo. A especial característica da ansiedade é o sentimento de insegurança e desamparo diante do perigo ${ }^{124 .}$

Podemos resumir que perigo seja a apresentação em público, principalmente como solista, ou melhor, tocar sozinho o trecho ou obra em questão, enquanto os demais músicos param de tocar seus instrumentos e tornam-se expectadores do

\footnotetext{
${ }^{122}$ Frederikson and Gunnarson 1922, p. 51-52.

${ }^{123}$ GREENE, Don, Figth Your Fear, 2001, p. 47-48.

${ }^{124}$ HAVAS, Kato, Stage Fright, p; 6.
} 
colega. Isto se dá pela sensação que o músico tem da incerteza do sucesso, e os julgamentos exteriores que irão fazer sobre suas habilidades musicais.

Um contrabaixista, ao fazer música de câmara ou tocando junto ao naipe da orquestra, possivelmente não terá problemas com a ansiedade em performance, pois nesta situação suas habilidades não estão em julgamento e sim as do grupo. Basta aparecer um solo, como a primeira de Mahler, onde a orquestra toda fica em silêncio e todas as atenções estarão voltadas ao $1^{\circ}$ contrabaixo, a ansiedade poderá ocorrer. Se esse músico tiver ansiedade em performance, estas perguntas virão a sua mente: Será que eu tocarei bem? Será que as notas sairão afinadas? Este solo será um sucesso ou um completo fracasso?

A ansiedade em performance e seus sintomas é ainda maior, quando o músico concorre a uma vaga de trabalho na orquestra. Nesse tipo de situação costuma ocorrer a falácia mental, ou comumente chamada de "tagarelice mental" pela qual abstrai-se do foco principal que é a performance.

Barry Green ${ }^{125}$, autor do livro Inner Game of the Music, possui uma teoria muito interessante dessa tagarelice mental. Quando temos a sensação de uma voz falando conosco mentalmente, ele denomina como Eu 1. O Eu 2 é o ouvinte dessa voz mental. Nessa interação poderíamos definir o Eu 1 como emissor eu o Eu 2 como receptor.

Segundo Green, o Eu 1 é o que nos causa a interferência. Ele contém nossas concepções de como as coisas devem ocorrer, são nossos julgamentos, associações ou comparações. Frequentemente nos diz mentalmente o que devemos e não devemos fazer e como deveria ter sido.

O Eu 2, por sua vez, é o vasto reservatório de potencial dentro de cada um de nós, que contém nossas habilidades e talentos naturais que é um recurso virtualmente ilimitado que podemos desenvolver.

Em suma se interfere no seu potencial é chamado de Eu 1 e se expressa o seu potencial é o Eu 2.

Alguns músicos tentam sanar o problema da insegurança da performance por não estarem tecnicamente prontos. O que pode ser até verdade, porém, na maioria

${ }^{125}$ GREEN, Barry. The Inner Game of Music, p. 16. 
das vezes é o Eu 1 se manifestando e impendido o crescimento musical. Pensamentos como "lá vem a parte difícil", "será que consigo tocar este salto sem desafinar" acabam por confundir as ordens que emitimos ao cérebro. Em realidade gera um antagonismo, pois o músico quer executar o salto, mas o Eu 1 se manifesta e diz que sairá desafinado o trecho em questão. A problemática surge, quando internalizamos o Eu 1. Grande parte do aprendizado humano vem de experiências e comparações, a partir das quais o resultado pode ser êxito ou não. A melhor maneira de eliminar as dúvidas e os medos provocados pelo Eu 1 é eliminar seus efeitos sob o nosso psicológico.

Green denota Eu 1 como algo que tenta tirar nossa atenção da música que estamos tocando ou ouvindo. Aliás, compara-o como uma criança interrompendo uma conversa ou uma freada de pneus em uma avenida. $E$ ainda diz o que fazemos quando somos interrompidos por algo. Se uma criança tenta interromper-lhe a conversa, sua atitude é ir a outro lugar ou falar mais alto e continuar conversando com o seu interlocutor; quanto à freada de pneus, basta pensar que o ocorrido foi apenas uma simples freada, focando-se ainda mais em sua conversa, que em nosso caso é forçar-se ainda mais na execução do instrumento.

É claro que alguns não conseguirão desconectar-se do Eu 1, e ele simplesmente pode não desaparecer. Uma sugestão prática é apenas não responder a sua tagarelice.

Geralmente músicos têm melhor performance, quando estão relaxados. Pois é neste momento que o Eu 2 está presente, e os efeitos prejudiciais da ansiedade de performance ou medo de palco não estará lá. Um fato interessante para demonstrar o estado do Eu 2 são os músicos ciganos. Eles tocam coisas dificílimas, principalmente os violinistas com suas Csardas e Zingarescas, e muitos deles tocam musica puramente de ouvido. Da mesma maneira os Jazzistas ou os que tocam música Pop. Todos têm algo comum: nenhum deles espera a perfeição, simplesmente fazem sua música sem julgamento exterior sobre técnica ou sonoridade, por isso simplesmente fazem sua arte sem compromisso.

Por outro lado, as regras do mundo da chamada música clássica ou erudita são extremamente rígidas, no que se refere à execução do instrumento e, como disse Dalai Lama: “Aprenda as regras e só saberá como quebrá-las”. 
Assim, passaremos a discutir algumas técnicas para eliminar ou suavizar os efeitos da ansiedade de performance.

\section{Beta Bloqueadores}

Beta-bloqueadores bloqueiam os receptores para os efeitos físicos presentes na ansiedade de performance, que são muito parecidos com o ataque de pânico. Eles não são calmantes, e eles não podem ajudar a ansiedade de natureza puramente psicológica. Os receptores beta são encontrados em vários lugares do corpo: pulmão, coração, artérias, cérebro e útero, para citar alguns. Como uma chave na fechadura, os bloqueadores beta quimicamente encaixam em receptores beta e evitam norepinefrina da ligação aos receptores que causam os sintomas da reação lutar ou fugir.

O grau desses efeitos depende da dose e da sensibilidade do indivíduo ao medicamento. Seu efeito máximo ocorre em $1 \mathrm{~h}$ ou $1 \mathrm{~h} 30$. Idealmente, isso pode permitir que o instrumentista "faça o seu melhor", sem distração ou interferência excessiva dos sintomas da ansiedade.

O efeito dos Beta bloqueadores pode causar diminuição da frequência cardíaca; diminuição das contrações do coração; broncoespasmo (pode causar ataques de asma em pessoas com asma), as contrações uterinas, pressão arterial diminuída, alívio de dores de cabeça e diminuiu tremor.

Inderal é o beta bloqueador frequentemente mais usado no meio musical. No Brasil o acesso a esse medicamento é bastante simples, pois não se trata de medicamento controlado e pode ser adquirido em qualquer drogaria.

Atualmente, com o aumento de estudantes de música, é natural que a demanda de profissionais aumente, porém não se criam tantas orquestras ao ponto de absorver os jovens músicos. Com o aumento do contingente de músicos sem trabalho em orquestra para todos, haverá mais competitividade entre eles. Curiosamente o nível técnico, musical e artístico estará cada vez mais elevado. Isso se dá pela competitividade. Para ilustrar esse assunto, em 2004, quando ingressamos na Orquestra Sinfônica de Porto Alegre - OSPA, havia vinte e quatro candidatos e tivemos a sorte de ser o único ganhador. 
Por essa competitividade o problema da ansiedade de performance está presente. Apenas uma ou outra nota fora do lugar poderá desclassificar o músico e cair por terra muitas horas de estudo e dedicação. Com tudo isso, o beta bloqueador é usado para amenizar esses efeitos, sendo comum no meio musical no qual muitas pessoas fazem uso, mas não admitem.

Não somos contra o uso do Inderal, desde que usado com parcimônia, e seu uso deve ser acompanhado por um médico. Seu uso poderá ter efeitos colaterais, tais como distúrbios do sono, alucinações, depressão, fadiga, redução do fluxo sanguíneo.

Nossa consideração contrária é que, ao usar o beta bloqueador, a interpretação musical poder ser reduzida expressivamente. Isso acontecerá exatamente pelo efeito do remédio, o músico poderá mecanicamente acertar todas as notas, porém o resultado de sua performance poderá ser mecânica e chata. $\mathrm{O}$ beta bloqueador reduz o ritmo cardíaco e consequentemente bloqueia os efeitos da ansiedade, que também bloqueiam as emoções, indispensáveis para a produção artística. Assim, se desejado um alto nível artístico na qual caminha a emoção, esse aparato farmacêutico não produzirá os efeitos desejados.

A solução para a ansiedade de performance é primeiro consultar um profissional da área da saúde e de forma criteriosa buscar a solução. As causas podem ser de ordem psicológica ou psiquiátrica e daí, se for o caso, fazer uso da farmacologia para ajudar eliminar o problema da ansiedade de palco. Por outro lado, o problema da ansiedade pode estar relacionado à forma que o músico se prepara para a performance, o que trataremos adiante.

\section{Prática X Performance}

Nosso derradeiro assunto trata da performance propriamente dita. Ao longo do trabalho, mencionamos assuntos relacionados a biomecânica, ergonomia, os aspectos fisiológicos e rotinas de prática e todos eles deságuam em um mesmo lugar: a execução musical.

Ressaltamos que a performance difere muito da prática e dizemos por quê. De forma geral o instrumento é praticado em casa, no conservatório ou faculdade de 
música. A acústica desses lugares é totalmente diferente das salas de concerto onde nos apresentamos.

Mencionamos que o problema de acústica não está presente nos contrabaixistas que tocam jazz, isto é, eles tocam com captadores; assim, as diferenças externas em relação à acústica serão mínimas.

Em uma sala de concerto há muitas diferenças entre a performance e o estudo de forma doméstica. Desde o tipo de roupa usada pelo músico, como sapatos: calças, camisas, casacas, smoking, luzes e temperatura apenas para citar algumas. Sem falar da informalidade do estudo, durante o qual o músico pode parar e repetir o trecho tantas vezes for necessário para melhorá-lo de forma técnica ou musical. Na performance é crucial que não haja erros ou minimizá-los o máximo possível.

Quando o aluno, ou até mesmo muitos profissionais, toca uma obra de forma descompromissada a tendência é que ela saia mais bem executada, diferentemente de quando é exigido, ou suas habilidades técnicas são colocadas em questão. Basta imaginar o seguinte problema: o músico $\mathrm{X}$, candidato a uma vaga como contrabaixista de uma orquestra. $\mathrm{X}$ é muito talentoso e possui bom domínio sobre 0 conteúdo a ser tocado no exame para ingresso à orquestra. Acontece que sua prática, em diversas horas sobre a peça confronto, livre escolha e excertos de orquestra, pode não ser tão bem sucedida. Pode ser que o músico execute isoladamente esses itens com proficiência, mas pode não possuir a resistência necessária para tocar todas de forma contínua.

Na maioria das vezes a prova para ingresso na orquestra segue o modelo: os candidatos, previamente inscritos, chegam ao lugar e no horário predeterminado. Ocorre um sorteio para a ordem do concurso, ou seja, a ordem em que os músicos irão tocar. A prova é feita atrás do biombo, onde em tese a banca examinadora do concurso não sabe qual candidato irá tocar.

O candidato à vaga tocará e terá apenas uma chance de demonstrar seus conhecimentos técnicos/musicais para a vaga de orquestra. Ou seja, o cenário entre prática e performance é totalmente diferente e, desse ponto em diante, propomos algumas soluções sobre o problema. 
A transição da prática para a performance tem que ver com o fator continuidade. Essa continuidade se desdobra em uma situação de estudo que é a prática da performance.

A continuidade está intrinsecamente relacionada à prática da performance. De forma geral estudam-se as obras de forma isolada somente em algumas oportunidades, como é o caso do exame de orquestra, recitais ou como solista que o músico terá que executar todo o programa do começo até o fim. Fatalmente the faltará resistência muscular ou física a tocar um programa de cinquenta minutos. Isso se dá pela ausência de prática em performance.

Uma boa maneira de adquirir essa resistência é construir repertório de maneira expansiva. Incorporar aos poucos as músicas necessárias até possuir repertório de mais ou menos cinquenta minutos. Outra forma é tocar o programa do começo ao fim e, nesse momento, não se preocupar com pequenos problemas de afinação ou imperfeição de algumas notas. Lembre-se esta sugestão é para a prática da performance e não para a solução de problemas técnicos como afinação, articulação ou qualquer imperfeição. ${ }^{126}$

Músicos analíticos, que esperam a perfeição, costumam em sua prática de estudo parar e repetir o trecho imperfeito. Isso causa problema na continuidade. Chegam a parar até compasso por compasso, ou seja, em casos extremos podemos comparar como se fosse uma gagueira, porém, musical.

Uma solução bastante simples é gravar o programa musical pretendido de forma contínua sem parar da capo ao fine. E lembramos novamente que o músico não deve fixar sua atenção em pequenos erros. Esses erros não ficarão para trás, pois serão inventariados e solucionados com exercícios e estudos. Esse inventário ficará por conta de um gravador de áudio ou vídeo, recomendamos para áudio o H4n e para vídeo o Q3 ambos da marca ZOOM. Ambos os aparelhos foram projetados para uso doméstico, porém, pelo fato de ser digital sua qualidade de áudio e vídeo são digitais e muito próximas de um estúdio profissional.

De forma geral o músico contrabaixista fica atrás do instrumento, ou seja, da sua caixa de ressonância. Em síntese a projeção sonora fica a frente do músico e às vezes fica difícil ouvir o que realmente esta acontecendo. Da mesma forma que

${ }^{126}$ GALAMIAN, Ivan. Principles of Violin Playing \& Teaching, p. 100. 
estranhamos ao ouvir nossa própria voz, acontece algo semelhante ao ouvirmos nossa própria gravação junto ao instrumento.

Feita a gravação, o músico passa de emissor a expectador ou ouvinte. Com o auxílio das partituras da obra em questão poderá fazer anotações e inventariar os erros e acertos de forma crítica.

Michael Wolf ${ }^{127}$ possui abordagem muito próxima da nossa e usa o termo "simulação do concerto". Afirma que a simulação ajuda a atingir a "atmosfera" da sala de concerto em seu próprio quarto ou estúdio. Diz ainda que recitais informais para grupo de amigos são o ideal para essa preparação.

Outra possibilidade prática para o músico é marcar uma hora exata ou a mesma hora para o concerto ou exame começar. Assim, basta ligar o gravador ou câmera exatamente na hora da simulação e tocar o programa inteiro. Wolf, ainda menciona que uma das mais poderosas ferramentas disponíveis para simulação de performance em público é usar um método de "auto-hipnose", em que visualize mentalmente a sala de concerto. O músico, ao evocar sensações e emoções, estará próximo da experiência da performance propriamente dita. Essa simulação inclui até a roupa usada no concerto, ajustando a estante de partitura (se for o caso) e, se possível, tentar ao menos tocar uma vez na referida sala de concerto ou tentar praticar em alguma semelhante.

Complementando as ideias propostas pelo professor Michael Wolf, temos uma sugestão também relacionada à simulação. A ansiedade de palco que já mencionamos e que para alguns músicos causa aumento dos batimentos cardíacos e sudorese, acaba sendo um fator externo ausente na prática diária do músico, pois somente aparece nas ocasiões da performance. Achamos que, em parte, é possível simular alguns efeitos da ansiedade e inclui-la em nossa simulação. Bastam alguns minutos de atividade aeróbica e podemos aumentar nossos batimentos cardíacos e simular um dos sintomas da ansiedade de performance. Por consequência, ao gravar nossa execução no instrumento sob esses efeitos, também simulamos o que realmente acontece em nosso jogo (concerto) diferentemente do que acontece em nosso treino (prática).

${ }^{127}$ WOLF, Michael. Principles of Double Bass Technique, p.178. 


\section{CONCLUSÃO}

Do nosso ponto de vista, o estudo burila o talento a desenvolver-se. O talento sem estudo, sem a consciência dos aspectos biomecânicos, fisiológicos e limites da máquina humana produz um artista espontâneo, porém incompleto, como uma pedra preciosa a ser lapidada.

Mostramos os aspectos biomecânicos e a otimização em performance de forma lógica, provocando o silogismo com as mais diversas formas de tocar e praticar o contrabaixo acústico e seus reflexos.

Em suma, o campo da arte em praticar um instrumento de forma metodológica não é ainda um lugar comum nas escolas de Música brasileiras. Em nosso país, o campo metodológico para estudar um instrumento é muito pequeno. Acreditamos que há inúmeras habilidades que podem ser desenvolvidas e depende da atividade intelectual e metodologia à parte, ou seja, um trabalho cognitivo direcionado fora do instrumento.

Ao longo de nossa pesquisa tentamos buscar o que há de mais novo e efetivo, no estudo do instrumento atualmente. Obviamente as combinações e formas de estudos são infinitas e podemos parafrasear como nas pirâmides que o "Segredo do Contrabaixo é Estudar". E encerramos nosso trabalho invocando Arthur Rubistein que uma vez disse: "Se você estuda 100 por cento irá tocar 75 por cento. Assim devemos praticar o instrumento em 200 por cento". E isso significa que devemos usar todas as ferramentas disponíveis; mental, física, emocional, racional e irracional e foi exatamente isso que tentamos relatar ao longo deste trabalho. ${ }^{128}$

\footnotetext{
${ }^{128}$ ELSON, Margret Elson. Passionate Pratice, p. 85.
} 


\section{REFERÊNCIAS}

ALEXANIAN, Diran. Complete cello technique. The Classic Treatise on Cello Theory and Pratice. New York: Dover Publications, 2003.

AUER, Leopold. Violin Playing as I Teach it. New York: Dover Publications, Inc, 1960.

BARKER, Sarah. A técnica de Alexandre: Aprendendo a usar seu corpo para obter energia total. São Paulo: Summus, 1991.

BENFIELD, Warren. The art of double bass playing. Miami, Florida 33014: CummyBirchard Inc, 1973.

BILLÈ, Isaia. Nuovo Metodo per Contrabasso. Parte I Corso teorico-pratico. Milão: RICORDI.

BOTTESINI, Giovanni. Metodo per Contrabasso. Milano: G.RICORDI \& C. Editori, 1991.

BRADETICH, Jeff. Double Bass: Ultimate Challenge. Idaho : Music For All To Hear, Inc, 2009.

BRUN, Paul. The New History of the Double Bass. Villeneuve d'Ascq - France: Pau Brun Productions, 2000.

BRUSER, Madeline. The Art of Pratice. New York: Tree Rivers Press, 1997.

BUNTING, Christopher. Essay on the craft of' cello-playing, vols 1 \&2. Melborne 3206 Australia: Cambrige University, 1982.

CONABLE, Barbara H. e CONABLE, Willian. How to Learn the Alexander Technique. Portland: Andover Press, 1995.

CONABLE, Barbara. What Every Musician Needs to Know abou the Body. Portland, Oregon 97203, 2000.

ECO, Humberto. Metodologia - Como se faz uma tese. São Paulo: Perspectiva, 1992.

ELSON, Margret. Passionate pratice: the musician's guide to learning, memorizing , and performing. Oakland: Regent Press, 2002.

FELDNKRAIS, Moshe. Consciência pelo movimento. São Paulo: Summus, 1977. 
FISCHBACH, Gerald F.; FROST, Robert S. Viva vibrato! A Comprehensive, Friendly, and Effetive Course of Study for Development of Vibrato on String Bass. San Diego, Califórnia: Neil A Kjos Music Company, 1997.

FISCHER, Simon. Pratice, 250 step-by-step pratice methods for the violin. London: Edition Peters, 2004.

FREGTMAN, Carlos D. O tao da Música. São Paulo: Editora Pensamento Ltda.

FREYMUTH, Malva Susane. Mental Pratice an Imagery for Musicians: a practical guide for optimizing pratice time, enhancing performance, and preventing injury. Boulder, CO: Integrated Musician's Press, 1999.

GALAMIAN, Ivan. Principles of violin playing \& teaching. New York: A Simon \& Schster Company Englewood Cliffs, 1985.

GALE, B. Thomas, Technical Foundation Studies for Double Bass V. I.

GALE, Thomas B. Technical Foudation Studies for Double Bass, Volume I \& II. Huntsville: AMERICAN SCHOOL OF DOUBLE BASS , 2000.

GERLE, Robert. The art o bowing prtice: the expressive bow technique. London: Stainer \& Bell, 1991.

GOÏLAV, Yoan. The Double Bass, a philosophy of playing, history - pedagogy technique. Québec - Canada: Les éditions Doberman - Yppan, 2003.

GOLEMAN, Daniel, Ph.D. Inteligência emocional. a teoria revolucionária que define o que é ser inteligente. Rio de Janeiro: Objetiva, 2001.

GOLEMAN, Daniel. A arte da meditação; um guia para a meditação. Rio de Janeiro: Sextante, 1999.

GOODE, Michael. Stage frigth in music performance and its relationship to the unconscious. Oak Park, Illinois 60301: Trumpetworks Press, 2003.

GREEN, Barry. Advanced Techniques Of Double Bass Playing. 2004.

. The inner game of music. New York: Doubleday, 1986.

GREEN, Barry. The Mastery of Music Ten Pathways to True Artistry. Broadway Books New York, 2003.

GREEN, Elizabth A. H. Practing Successfully, A Masterclass in the Musical Art. Chicago: Gia Publications, Inc., 2006.

GREENE, Don. Figth your fear and win: seven skills for performing your best under pressure; at work, in sports, on stage. New York: Broadway Books, 2001. 
. Performance Success: performing your best under pressure. New York: Routledge, 2002.

GROODNER, Murray. An Organized Method of String Playing, Double Bass Exercises for Left Hand. Bloomington, Indiana: Peer Internationl Corporation, 1977.

HAVAS, Kato. Stage Frigth its Causes and Cures. London: Bosworth \& Co. Ltd.

HAY, Louise L. Aprendendo a vencer o medo. Rio de Janeiro : Sextante, 2004.

HORVATH, Janet. Playing (less) Hurt. An Injury Prevention Guide for Musicians. Self-published by Janet Horvath, 2009.

I SADIE, Stanley. II LATHAM, Alison. Dicionário Groove de Música: edição concisa. Rio de Janeiro: Jorge Zahar, 1994.

KARR, Gary. The Gary Karr DoubleBass Book, Vols I, II e III. Victoria, B.C., V8Y2A6: Amati Productions, 2002.

KATZ, Lawrence C. Mantenha seu cérebro vivo: exercícios neuróbicos para ajudar a prevenir a perda de memória e aumentar a capacidade mental. Rio de Janeiro: Sextante, 2000.

KEMPTER, Susan. How muscles learn: teaching the violin with the body in mind. Van Nuys, CA: Alfred Publisching Co., Inc., 2003.

KLICSTEIN, Gerald. The musician's way: a guide to pratice, performance, and wellnes. New York: Oxford Universty Press, 2009.

LEVINSON, Eugene. The school of agility. New York: Carl Fischer, 2002.

LIEBERMAN, Julie Lyonn. You are Your Instrument. The Definite Musician's Guide to Pratice and Performance. New York: Huiksi Music, 1995.

MACTIER, Duncan. Daily Exercises for Double Bass. Mctier Music, 1994. .Tips and Tricks, Vols 1 \& 2. McTIER MUSIC, 1999.

MANTEL, Gerhard. Principles and Forms of Movement. Indiana: Indiana University Press, 1995.

MARCHETTI, Paulo; Ruy CALHEIROS. Biomecânica Aplicada, Uma Abordagem para o Treinamento de Força. São Paulo: Phorte editora, 2007.

MARK, Morton. Miraculous Scale Fingerings for the Double Bass. Columbus Ohio: Basso Profondo Publications, 1991.

MORTON, Mark. Dr. Morton's double bass technique: concepts and ideas. Columbus, oh: Basso-Profondo Publications, 1991. 
. Miraculous! Arpeggio fingerings for the double bass. Columbus - Ohio: Basso Profondo Publications, 1991.

MOTTO, David. Musician's Pratice Planner. MoltoMusic, 2006.

O'BRIEN, Dominic. Aprenda usar sua memória: descubra seu potencial e desenvolva técnicas para não esquecer mais nada. São Paulo: Publifolha, 2004.

PETRACCHI, Francesco. simplefied higher technique for double bass. London: yorke edition, 1982.

PLEETH, William. CELLO. London: Halstan \& Co Ltd, Amersham, Bucks, 2001.

PRUNNER, Joseph. Escalas e arpegios para Contrabaixo "manuscrito".

RABATH, Fraçois. Nouvelle technique de la contrabasse, vols $i$ ii \& iii. Paris: Alphonse Leduc, 1980.

REINKE, Gerd. Carl Flesch. Scale System. Berlin: Verlag Von Ries \& Erler, 1994. . SEVCIK Op.2 School of Bowing Technique. London: Bosworth \& Co, 1988.

ROBERTA, Roesch. Organize-se! Como administrar seu tempo e espaço de forma a ser eficiente, sem precisar modificar seu estilo pessoal. São Paulo.: Harbra Ltda., 1989.

ROBINSON, Lynne; NAPPER, Howard. Exercícios Inteligentes com Pilates e Yoga. São Paulo: Editora Pensamento - Cultrix Ltda., 2002.

ROETTINGER, Ida. Head Hand and Heart. Ann Arbor, Michigan: Photolithoprinter by Cushing - Malloy, Inc, 2000.

SAZER, Victor. New Directions in Cello Playing. Los Angeles: Ofnote, 2003.

SIMANDL, Franz. New Method for String Bass Vol. I e II. New York: International Music Company.

STREICHER, Ludwig. Sclale and Chords Studies for Double Bass. Müchen: Ludwig Doblinger, 2000.

STROBEL, Henry A. Useful measurements for violin makers. Aumsville OR, 97325: Henry A. Strobel, 2008.

TRUMPF, Klaus. Compendium of Bowing Techniques for the Double Bass, Vols I e II. Leipzig: Veb Deutscher Verlag für Musik - Leipzig, 1989.

VINEYARD, Missy. How You Stand, How You Move, How You Live. Philadelphia: Da Capo Life Long, 2007. 
WOLF, Michael. Grundalagen der Kontrabass - Technik = Principles of double bass technique. Verlag Die Blaue Eule, 1991. 